\title{
Estudios municipales de Manila
}

\author{
I. AYUNTAMIENTO Y SOCIEDAD \\ ANALISIS SOCIO-DEMOGRAFICO \\ DE LA POBLACION DE MANILA (1571-1800)
}

\section{INTRODUCCION}

Cuando hace aproximadamente un año nuestro interés por los estudios de las instituciones hispánicas tuvo ocasión de reactivarse y comenzamos la preparación de la Historia del Cabildo Secular de Manila, uno de nuestros ineludibles cometidos hubo de ser la recogida de datos y referencias relativos a la población ciudadana de la Capital del Archipiélago. Queríamos documentar nuestro trabajo con lo más importante que se pudiese encontrar respecto a la sociedad española de Manila que pudiese servir de base a conclusiones y enjuiciamientos sobre el gobierno municipal, ya que siendo éste la resultante de aquélla, la vía de la evaluación global del municipio quedaría expedita al conocer la base de la que partía.

Deseábamos asimismo eliminar con este enfoque las justificadas críticas hechas a trabajos de esta índole para el área hispanoamericano por haber estudiado un tanto abstractamente la institución municipal sin una vital referencia a la sociedad en que ella misma se encarna, pues no puede hacerse buena historia del gobierno ciudadano sin hacerla simultáneamente del complejo sociohumano en que se asienta.

Nos interesaba, desde luego, prescindiendo de las vagas generalidades bien conocidas sobre la población de Manila y las islas, el dato empírico, la referencia clara y el guarismo exacto, estando en principio dispuestos a rechazar cualquier apreciación general que no viniese expresada en proporción, número y medida. Tras horas de lectura del material publicado al respecto, hubimos de convencernos de la ausencia casi generalizada de evaluaciones demográficas concretas en los autores y cronistas de la historia de Filipinas 
que sirviesen nuestro propósito, lo cual era, descle luego, de esperarse, ya que ahora por entonces la historia de la preocupación estadística, sociológica y demográfica de nuestros días, no podía el historiador de épocas remotas buscar respuesta a una cuestión que aún no tenía planteada

Nos habian ilustrado los historiadores clásicos, eso sí, sobre la realidad de la escasa población, pero casi siempre sin determinar su número, y mucho menos sin especificar su clase. Nuestra hipótesis de trabajo, por el contrario, se basaba en la posibilidad de concretar a número las vagas referencias sobre esa población española, y de encuadrarla en esquemas sociológicos que nos dijesen algo sobre el complejo ciudadano, especialmente de la Capital, puesto que ella - bajo la forma institucional del municipio- iba a ser el principal objeto de nuestro estudio.

Como primer paso para explorar la hipótesis, fueron preciso recurrir a las fuentes primarias en los conocidos repertorios documentales, haciéndonos concebir su preparatoria lectura satisfactorias esperanzas de poder realizar el proyecto al menos en una primera fase.

Posteriormente, el interés de la Embajada Española por el tema general de la Historia del Cabildo Secular de Manila y la valiosa recomendación de la misma Embajada hicieron posible que el Instituto de Cultura Hispánica de Madrid financiase substancialmente nuestra investigación inmediata en los Archivos españoles. Fruto de esta investigación es el copioso material que hemos recogido sobre el tema principal del Cabildo o Ayuntamiento de Manila, y que en estas páginas empezamos a presentar bajo el título general de ESTUDIOS MUNICIPALES DE MANILA*.

* Tenemos en preparación los siguientes estudios en la serie de la Historia del Cabildo Secular, o Ayuntamiento, de la M.N. y S. L. Ciudad de Manila:

II. Alcaldes y Regidores: La Venta de Oficios y el Acceso a los puestos municipales de Manila.

III. Propios y Finanzas; Los presupuestos del Ayuntamiento.

IV. Fiestas y Ceremonial: Edición Bilingüe del "Ceremonial de las Asistencias y Funciones de la Noble Ciudad de Manila".

V. El "Cabildo Abierto" en Manila.

VI. La Constitución de 1812 y el Ayuntamiento Provisional

VII. El Ayuntamiento y los Servicios Públicos; Policía, Bomberos y Sanidad.

VIII. Ayuntamiento y obras Públicas.

IX. Alumbrado.

$\mathbf{X}$. Parques y Jardines.

XI. Calles, mercados y puentes.

XII. La Obra Pía de Carriedo y la Traída de Aguas.

XIII. Las Casas Consistoriales. 
Por lo que se refiere al análisis cuantitativo y cualitativo de la población, que forma el tema de esta primera monografía, recogemos una buena parte de las referencias documentales dispersas en las colecciones de fuentes primarias, comprobadas en sus originales y suplementadas con documentación inédita que nos ha permitido ese inicial encuadre sociológico al que acabamos de aludir arriba. Nuestro escarceo demográfico ha hecho posible el concretar a números la curva evolutiva de la población ciudadana de Manila, década por década en los primeros sesenta años siguientes a la fundación de la ciudad, así como, en ocasiones, el asiento y desarrollo periférico de esa misma población en las islas.

La clasificación en grupos sociales y los análisis cualitativos a que dan lugar nos hubiesen resultado imposible de realizar de no haber sido por la riqueza de detalle de los documentos originales que describimos a continuación.

\section{Presentación y descripción del material de archivo}

Nos valemos principalmente de tres listas de pobladores remitidas al Consejo y al Rey por el Gobernador Don Francisco Tello al final del siglo XVI. Llevan los siguientes títulos:

1. "Memoria de las personas beneméritas que ay en las yslas philipinas y los que tienen gratificacion o no, de sus servicios, y quienes estan gratificados y la renta y hazienda que cada uno tiene y los sujetos y partes, comencando por los primeros encomenderos que binieron con el adelantado miguel lopez de legaspi, y conquistaron y pacificaron estas yslas entrando por cibu ques la provincia de printados donde primero poblaron" (N. ${ }^{\circ} 1$ del Suplemento Documental).

2. "Memorial de las personas Venemeritas de las yslas filipinas que an servido a su magd. en la Reducion pacificacion y conservacion dellas sin que se les aya dado gratificacion de sus servicios" (N. 2 del Suplemento).

3. "Lista y memoria de los Vezinos de las Yslas Philipinas que no estan encomendados y el tiempo que cada una a que esta en ellas por su abecedario" (N. ${ }^{\circ} 3$ del Suplemento).

XIV. La Reforma de Maura y el Ayuntamiento de Manila al fin del Régimen Español.

XV. La Correspondencia del Ayuntamiento con el Gobierno Central: (Selección y Edición Bilingüe). 
Los tres documentos llevan la signatura Patronato, 25 del Archivo General de Indias de Sevilla; los dos primeros pertenecen al Ramo 54 del mismo legajo y el tercero es parte del Ramo 55. Los tres fueron remitidos con carta del Gobernador Tello de 12 de. julio 1599 en la que aparecen mencionados expresamente en los párrafos 23 y 24. El tercero de ellos, además, lleva la firma autógrafa del Gobernador.

Estas tres listas, sin duda conocidas por los historiadores especializados, no han sido debidamente estudiadas, y han permanecido substancialmente inéditas; por su valor para la demografía de grupos con apropiado enfoque histórico, y por ser la base de las apreciaciones tanto cualitativas como cuantitativas de nuestros análisis en este trabajo las publicaremos en Suplemento Documental.

Inédito igualmente, $\mathrm{y}$ de no menos interés y valor, es el censo municipal de Manila de 1634, que ofrecemos bajo el N. 4 del Suplemento. La riqueza informativa de este documento y su valor confirmatorio de las afirmaciones que se expresan en el texto de esta monografía justifican su publicación. Fue preparado por el Ayuntamiento, a petición del Gobernador Cerezo de Salamanca, quien anuncia su envío para la atención del Rey en carta de 10 de agosto de 1634. Lleva por signatura: Archivo General de Indias, Audiencia de Filipinas, 27.

La utilización que hacemos de este material esperamos ilumine de una forma distinta a la usual el problema de la escasa población española de la Capital y de las islas, sus números concretos y categorias sociológicas. Para nosotros ha sido una primera lección en el entendimiento de la base humana del Ayuntamiento de Manila y esperamos que para nuestros lectores sea un avance más en sus conocimientos de la historia de este entrañable Archipiélago.

\section{ANALISIS CUANTITATIVO}

\section{Fundación de Manila y población inicial}

Por abril de 1571, "a 20 del dicho mes", sale Legazpi de Panay "con la galeota en que yo iba y el patax San Lucas y una fragata y un junco y veintitres parao de indios de remo que iriamos en todos duzientos y diez españoles poco mas o menos". En Panay había dejado un contador y carpinteros para construir otra galeota de 12 a 13 bancos, más un capitán de artillería y unos soldados para guardarla. A 16 de mayo desembarca en Manila y se establece "a la pun- 
tá del rio donde ellos habian quemado sus casas" en la margen izquierda del Pasig .

Dos días después, el 18, estando presentes el P. Herrera, Goiti, Juan de Salcedo, Luis de la Haya, Andrés de Ibarra y otras personas principales del Campo, mediante los intérpretes Benito Diaz Busto y Juan Mohamat indio cristiano, otorgan vasallaje y paz perpetua ante Legazpi Raja el viejo, Raja Solimán el mozo y Lacandola, principales de los pueblos de Manila, Sibunao y Tondo, quienes declaran que habiendo confesenciado con los demás jefes y habiendo discutido "si les estaria bien hacer paz y amistad con los españoles y ser vasallos de su Magd... todos de comun consentimiento querian ser vasallos del Rey de Castilla nro. señor y por tales se ofrecieron desde agora por si y en nombre de todos los indos desta comarca porque lo que ellos tres hiciesen y asentasen lo ternian todos por bueno". Siguen los detalles de los ofrecimientos de Legazpi, la aceptación de vasallaje y las ceremonias de la toma de posesión. "Y fecha y asentada la paz y toma de la dicha possision - segun y como es uso y costumbre lo cual paso en haz y en paz de los dichos indios y dandoseles a entender como se tomaba la dicha posesionel dicho Sr. Gobernador les mando a los dichos indios que luego mandasen hacer $\mathrm{y}$ hiciesen acabar un fuerte que tenian comenzado en la punta de este rio donde se plantase y pusiese la artilleria de S. Magd. y que dentro del dicho fuerte hiciesen una casa para $\mathbf{S}$. Magd. y un camarin grande para cosas necesarias y que asimesmo fuera del fuerte havian de hacer una casa e iglesia para los religiosos en la parte y lugar que se les señalase y una casa para el dicho Gobernador, y que estas casas e iglesia havian de ser grandes y asimesmo havian de hacer otras ciento y cinquenta casas medianas en que se albergarse (s) la gente del campo, lo cual se pudiera haber excusado si ellos no quemaran como quemaron el pueblo, y asimismo se trato y dixo que viesen ellos que orden se debia dar para que los soldados no les tomasen cosa alguna de sus haciendas y se pudiesen sustentar sin les hacer daño y ellos todos de una conformidad dixeron y prometieron que harian los edificios y casas arriba declarados y que acabada la obra de las dichas casas darian comida en este pueblo a trescientos españoles ordinariamente de los mantenimientos y comida que ellos usan y tienen en esta tierra..." ${ }^{2}$.

1. A.G.I., Patronato 24, Ramo 23: "Copia de carta de Legazpi al Virrey de Nueva España": 11 de Agosto de 1572.

2. A.G.I., Patronato 24, Ramo 24: Certificación notarial, firmada conjuntamente por Legazpi y Hernando Riquel. 
Subsiguientes atestaciones oficiales del escribano Hernando Riquel nos ofrecen esta secuencia de actos fundacionales: a 3 de junio Legazpi da a Manila el título de ciudad; el 24 funda su Ayuntamiento con dos Alcaldes Ordinarios, un Alguacil Mayor y doce Regidores; a 25 "nombro un escribano de Cabildo y dos escribanos publicos para el juzgado de los dichos Alcaldes"; a 28 del mismo mes se reunió por primera vez el recién fundado Ayuntamiento, bajo la presidencia del Adelantado-Fundador que promulgó en esta primera sesión las ordenanzas corporativas del Cabildo ${ }^{3}$.

La fundación oficial de Manila como ciudad de españoles fue, pues, el 24 de junio de 1571. Legazpi mismo lo describe con sencillas palabras: "El dia de San Juan Bautista se fundo en nombre de $\mathbf{S}$. Magd. en este rio una poblacion de españoles con su Justicia y Regimiento y otros oficios de republica y se le puso por nombre la ciudad de Manila de la Provincia de la Nueva Castilla por respeto a un pueblo que se hallo diez leguas de aquí llamado Castilla de su nombre"

Observemos, sin embargo, que a parte de la fundacién oficial el 24 de junio - la ciudad nace ante la ley con la constitución de su Cabildo-, el asentamiento de vecinos hubo de comenzar inmediatamente después de la toma de posesión de su emplazamiento en los días siguientes al 18 de mayo. La relación anónima de 1572 dice a este respecto:

‘...Bolveré a tratar de lo que el gobernador hizo después que desembarcó en Manila que fue a diez y seis de mayo de mill e quinientos y setenta e un año; luego desde en ocho dias echo vando que los que quisiesen ser vecinos en la ciudad de Manilla, que en nombre de su Magestad se fundaba, que les daria solares y rrepartimiento como su Magestad lo mandaba, y ansi se asentaron todos quantos con el venian, capitanes y soldados y gentiles ombres, por vezinos de la dicha ciudad; empero hasta agora, que a cerca de un año que se poblo, muy pocos son los que tienen rrepartimientos ni aun solares, que es muy mucho menos de la manera que tengo contado se poblo e fundo esta ciudad" 5 .

3. A.G.I., Patronato 24, Ramo 20: Certificaciones de Riquel a 19 de Junio de 1572 nota 1 .

4. A.G.I., Patronato 24, Ramo 24: Copia de carta de Legazpi; citada en

5. "Relación de la conquista de Luzón" (Anónima); publicada en W. E. Retana, Archivo del bibliófilo Filipino: Recopilación de documentos históricos, 
El Asiento como vecino era en las ciudades españolas un acto legal ante notario con todas las formalidades de la ley; los libros de registro de los inscritos quedaban al cuidado y custodia del notario de Cabildo. Nadie, parece ser, ha tenido la fortuna de encontrar hasta ahora ejemplares completos de los Libros de inscripción de vecinos de Manila y sólo de cuando en cuando aparecen certificaciones notariales sacadas de sus preciosas páginas. Este libro primero de asiento de vecinos hubo de contener, pues, los nombres de cuantos participaron en la expedición de fundación de la ciudad, que junto con Legazpi y el agustino Herrera, incluian al "maese de campo y todos los demas capitanes y doscientos e treinta soldados arcabuzeros" ". Notemos la ligera diferencia en los números: Legazpi dice, sin esfuerzo de ser exacto: "...iriamos en todos duzientos $y$ diez españoles poco mas o menos" "; la relación anónima da, ya se ha visto, doscientos treinta, excluidos Legazpi y su estado mayor. Si hubiésemos de decidirnos por la notación más exacta, preferiríamos el testimonio de la relación anónima. Redondeando la cifra, Manila quedó constituida en su primera fundación con unos 250 vecinos que sin deponer las armas pasaron a la condición de soldados-ciudadanos.

\section{Desarrollo posterior de la población en Manila y las Islas}

Con alrededor de 250 vecinos, Manila nacia fuerte y vigorosa y en posición abiertamente ventajosa con respecto a otras muchas ciudades indianas, pues su coeficiente de población vecinal la colocaria en el rango del $22.10 \%$ de los establecimientos de españoles en las Indias ${ }^{8}$. Por una coicidencia histórica, sólo cinco días después de la fundación oficial de Manila le llegaba a la nueva ciudad el primer refuerzo en los navíos Santiago y Sanjuan al mando de

científicos, literarios y políticos y estudios bibliográficos, I (Madrid, 1896), 1-37; cita en p. 19.

6. "Relación de la conquista de Luzón", en RETANA, Archivo I, 19.

7. Legazpi al Virrey de Nueva España: cf. nota 1.

8. Marta Milagros del Vas Mingo, "Instituciones jurídicas en la Geografía de Juan López de Velasco", III Congreso del Instituto Internacional de Historia del Derecho Indiano: Madrid, 17-23 de enero de 1972 Actas y Estudios (Madrid: Instituto Nacional de Estudios Jurídicos, 1973), p. 500 nos da esta clasificación de las ciudades hispánicas incluidas en la Geografía:

De más de 1000 vecinos: $2=(1.05 \%$ de total $)$

De más de 500 a $800 \quad 7=(4.21 \%$ del total $)$

De 100 a 400 : $\quad 43=(22.10 \%$ del total $)$

30 a $100: \quad 71=(36.85 \%$ del total $)$

De menos de $30: \quad 48=(25.53 \%$ del total $)$

Sin referencia: $\quad 20=(10.53 \%$ del total $)$

Total de ciudades: $\overline{191}$ 
Juan López de Aguirre, y en mayo de 1572 aportaron también Pedro de Luna y Juan de la Isla con la gente que venía en el "Espiritu Santo" ". Podríase haber esperado con estos augurales principios un crecimiento sostenido del núcleo inicial de pobladores. Sin embargo no fue así, porque como la Sociologia nos enseña, el crecimiento urbano está sometido a la dinámica de un número de factores y condiciones que por siglos no habian de realizarse en Manila ni en el conjunto de las islas del Archipiélago Filipino.

Ya Legazpi en su carta al Virrey de Nueva España sugiere que, al no tener sucesión los pobladores, por falta de mujeres, se repartan las encomiendas entre los que no han logrado ninguna "porque de otra manera no se podra sustentar ni conservar las poblaciones de españoles que se han poblado, que de cinquenta vecinos que quedaron poblados en Cebu de año y medio a esta parte han fallecido diez o doce y otros tantos estan enfermos y tullidos y los demas vecinos han querido despoblarse diciendo que no osan vivir entre los indios siendo tan pocos y cierto es cosa necesaria y que conviene al servicio de S. Magd: y a la población de la tierra que esto se provea con brevedad" ${ }^{10}$.

Aunque hemos de examinar más adelante cada uno de los extremos en particular, bien será ya anotar aquí que en la precedente apreciación del Adelantado van incluidos todos o casi todos los elementos que inciden en el retraso poblador de las islas: el bajísimo índice de reproducción, mas no precisamente por la falta de mujeres; el tenuísimo aliciente económico centrado en la encomienda y otras mercedes reales; la dependencia de Nueva España y del lejanísimo gobierno central; la exageradamente alta proporción de mortalidad; consecuencia de la inadaptación física al ambiente, de las bajas por guerras, de las fatigas y privaciones del soldado en vías de conseguir estado de ciudadanía en las islas; todos estos factores contribuyeron a esa inenarrable soledad del núcleo de colonos españoles en Filipinas por espacio de más de dos siglos. Pero expongamos ya las bases documentales de nuestro análisis cuantitativo de la población.

Reproducimos unos de los documentos más sustanciosos que nos dan una visión general del panorama de población y defensa, a unos diez años fecha de la fundación de Manila:

9. A.G.I., Patronato 24, Ramo 23: Legazpi al Virrey de Nueva España: 11 de agosto de 1572.

10. A.G.I., Patronato 24, Ramo 23. 
"Ahora dos años y medio me enviaron a pedir socorro del Maluco, y para ver el que les podia dar hice memoria de la gente y armas que habia en todas estas islas y escribi a todos los Alcaldes Mayores hiciesen copia de la gente y armas que habia en su distrito de cada uno, y esto fuese ante escribano y me la enviasen, las cuales son estas que van aqui" "1.

Sigue el documento del que extractamos en resumen: "En Manila donde yo residia" se encontraron 329 hombres "entre viejos y mozos" 204 arcabuces; 126 cotas; 192 espadas y 17 alabardas ${ }^{12}$. En Arévalo: 65 hombres; 39 arcabuces y 28 cotas. En Cebu: 63 hombres; 40 arcabuces y 35 cotas. En Cáceres 69 hombres; 35 arcabuces y 27 cotas. En Segovia: 97 hombres; 80 arcabuces y 63 co-

11. A.G.I.; Patronato 25, Ramo 1: "Relación de toda la gente de armas que habia en las islas Filipinas" (Sin firma, sin fecha). Es, evidentemente, este documento un resumen de las listas preparadas por orden de Diego Ronquililo en 1583. Usando las certificaciones a que el mismo alude, Ronquillo informa al Rey, expirado su mandato y ya fuera de Filipinas, probablemente, desde Nueva España.

12. Tenemos ante nuestra vista esta "Lista de las armas que ay en manila". Lleva el siguiente encabezamiento: "En la ciudad de Manila a treinta y un dias del mes de agosto de mill e quinientos y ochenta y tres años en cumplimiento de lo mandado por el $\mathrm{Sr}$. governador en presencia de $\mathrm{mi}$ el escrivano publico el sargento Francisco de Moral para saber la gente y armas que al presente ay en este campo anduvo por todas las casas desta ciudad y en ella parecio aver la gente y armas siguiente". La signatura es A.G.I., Patronato 25, Ramo 14.

Comenzando con el nombre de "El Capitan Pedro de Chavez..." incluye 312 nombres, siendo el último en lista "bergara que posa en casa de su Señoria Reverendisima, sin armas".

Curiosamente, bajo el número de orden 139 (número suplido por nosotros) leemos el nombre de "JUAN MASIAS espada y arcabud solo". Creemos que este Juan Masias es el Juan Macias identificado como el Maestro de la obra del Monasterio e Iglesia de San Agustín en Intramuros por los autores de nuestra historia religiosa. Según este dato, Juan Macias no habria sido Indio Pampango, si no español y soldado-ciudadano de Manila. Nos permitimos brindar esta pista a los investigadores de la Historia Religiosa de las Islas, muy especialmente a nuestro amigo condiscípulo, P. Isacio Rodríguez, OSA., a quien tanto debe ya la Historiografía Eclesiástica de Filipinas.

Puntualizamos que aunque no menos de 23 nombres aparecen con alguna designación profesional tales como: escribano, atambor, lombardero, licenciado, carpintero, barbero, mercader, etc., Macias no lleva la esperada de arquitecto, o cuando menos, alarife. Tampoco encontramos mención de él en las listas que tenemos reunidas de vecinos de Manila para años posteriores a 1583, lo cual nos hace pensar, pues que estaba aún vivo $\mathrm{y}$ en Manila, en la posibilidad de que hubiese solicitado el ingreso en la Orden...

La lista concluye así: "La qual dicha lista se hizo en la manera que dicha es el dicho dia mes y año dicho en presencia de mi el dicho escrivano de que doy fee testigo della Hernando de loaísa. Alonso merino escrivano publico". La có pia existente en el A.G.I. está autorizada por Alonso Beltrán, Escribano mayor de Gobernación y de minas y registros. 
tas. En la Villa Fernandina (Vigan): 19 hombres; 13 arcabuces y cotas.

"En la provincia de Pangasinan hay siete españoles con cotas y arcabuces. En la comarca de la ciudad de Manila y con la gente de mar que esta en Cavite que es el puerto donde estan los navios se hallaron 64 hombres los mas de ellos desarmados. $Y$ esta es toda la gente que en aquel tiempo se hallo en todas las islas Filipinas. Desta gente envie yo para socorrer al Maluco y la fortaleza de Amboino ciento y tres hombres con el Capitan Pedro Sarmiento".

La suma de hombres en los destacamentos españoles desde Arévalo a Vigan, como se habrá notado, no pasa de los 713 y de ellos fueron destacados al Maluco 103, dejando en las islas una población efectiva de sólos 610 soldados y vecinos, separados entre sí por cientos y cientos de kilómetros. Notemos, de paso, el dispendio de vidas de españoles por comparación con esta referencia, salida de la pluma de D. Gonzalo Ronquillo, deudo y antecesor de Diego Ronquillo en la gobernación de las islas:

"Yo truxe a estas islas 460 personas de mar y guerra $\mathrm{y}$ habia en ellas poco mas de seiscientos españoles, por lo cual entendera V. Excia. el gasto que la tierra va haciendo de gente, y cuanta necesidad ay de illa cevando siempre della, especialmente si todas las jornadas suceden como la de Burney la cual me certifican costo mas de ducientos españoles" ${ }^{13}$.

Por lo que respecta a la población ciudadana de Manila, tenemos dos testimonios de primera mano por este mismo tiempo:

"Tiene esta ciudad ochenta vecinos... Ay ordinariamente en esta ciudad doscientos soldados acoxidos entre los vecinos e por las casas de los yndios comarcanos a ellos muy pobres que se sustentan de limosna" ${ }^{14}$.

El Cabildo en carta de 25 de junio de 1586, expresando la opi-

13. A.G.I., Filipinas 6: Don Gonzalo Ronquillo a S.M.: 18 de junio de 1580 .

14. A.G.I., Filipinas 32: "Relación de los naturales que al presente ay... y de la cantidad de bezinos españoles asi en esta ciudad de manila como en las poblaciones de fuera dellas y de los ministros que son necesarios". Publicada en COLIN, Francisco, Labor evangélica de los obreros de la Compañia de Jesús en las Islas Filipinas, Ed. de Pablo Pastells, II (Barcelona 1900-1902) 674-681; 3 vols. 
nión corporativa sobre lo inoportuno y ruinoso del mantenimiento de la Audiencia, informa que en la ciudad de Manila habrá escasamente setenta vecinos y en todos los establecimientos de españoles en todas las islas no muchos más de ese número, por lo cual, recelosos de las injerencias de Castilla, los Portugueses... no pueden creer que se haya establecido solo para ciento treinta vecinos y unos pocos soldados" 15 .

Las expediciones de refuerzo de gente, cuando atendían a la necesidad "de illa cebando de ella", en la expresión de Ronquillo de Peñalosa, no lograban cambiar la situación estacionaria, y su sucesor, D. Diego, relevado por Santiago de Vera, concluía así su informe sobre la difícil situación de defensa y la escasa población:

\begin{abstract}
"Desde ha seis meses llego aquellas islas el doctor Santiago de Vera. Dicen metio en aquellas islas ducientos y siete soldados; los mas de los sesenta eran muchachos que no eran para servir. Entre todos ellos no se hallaron cien arcabuces ni veinte cotas. Destos soldados que llevo y de los que habia en aquellas islas, saco trecientos y tantos y los envio con el Capitan Morones al Maluco para reducir a quella fuerza que tienen aquellos moros al servicio de $\mathbf{S}$. Magd., cosa harto fuera de razon y orden, y asi entre los que le mataron y se ahogaron faltaron ciento y tres o ciento y cuatro hombres. De los demas que quedaron en las islas han muerto algunos, y echado cuenta con los que quedaron muertos y ahogados en la jornada hay bien poca gente en aquellas islas... Seis $u$ ocho dias antes que yo me partiese llegaron dos navios de la nueva españa y en ellos dos capitanes; dicen llevaban ciento y tantos hombres, no se de cierto los que eran ni las armas que llevaban" ${ }^{16}$.
\end{abstract}

El mismo Dr. de Vera corrobora estas apreciaciones de Ronquillo cuando años después, ya casi al final de su mandato, describe a Manila como "bolsa vacia o posada sin huesped", expresión que por su generalidad estaríamos dispuestos a desestimar, si no la encontrásemos avalada por los exactos cómputos numéricos que para

15. A.G.I., Filipinas 27: Cabildo Secular de Manila a S. M. Lo mismo expresa en su parecer favorable a la supresión de la Audiencia el Factor Juan Bautista Roman (140 vecinos), en las deliberaciones de la Junta General de todos los estados. Cfr. Colín-Pastells, Labor evangélica, I, 335. La carta del Cabildo aparece en traducción inglesa en la conocida colección documental de Blair, Emma, and Robertson, James, The Philippine Islands, 1493-1898, VI (Cleveland 1903) 243. En adelante, esta colección la citamos bajo la siglo $B \& R$,

16. Cf.. nota 11 . 
esta década venimos presentando. Refiriéndose el Doctor a la floreciente edificación de piedra, nos dice:

\begin{abstract}
"Las casas se ban apriesa edificando de piedra al huso de españa muy fuertes $y$ grandes $y$ de mucha autoridad y con el favor de díos en dos o tres años seran todos los edificios ansi... pero causa tristeza grande (que es todo como bolsa vazia o posada sin huesped) porque como la tierra no es bien sana y no hay medico ni medicinas y la necesidad tan grande en la gente de guerra y el trabajo ordinario de la guarda y demas centinelas y jornadas para hacer socoro a las poblaciones y pacificar las alteraciones de los indios, cada año se van muriendo y faltando de suerte que temo no ha de haber jente para de fender la ciudad..." ${ }^{17}$.
\end{abstract}

Con anterioridad a esta fecha Don Pedro de Rojas, en carta también a S. M., nos revela cómo ya operante en un sector de la población una justificada tentación al abandono y un natural deseo de evasión, al declarar que la población de las islas ha tenido grandes pérdidas y que en varios años se ha marchado más gente que ha venido; además casi todos están pendientes de obtener licencia de escapar y en consecuencia no se preocupan de establecer casa y hacerse ciudadanos estables que pudiesen dar prestigio e incremento a la colonia ${ }^{18}$. Esta amenaza de abandono, resultado del creciente desaliento por la "flaqueza de la tierra", junto con un frecuente deseo de repatriación los encontramos documentados repetidas veces y manifiestan una pronunciada insatisfación con las condiciones prevalentes ${ }^{19}$.

El movimiento de la población urbana de la capital experimenta en la década de 1590 a 1600 una ligera recuperación; recuperación que al parecer se logra tanto por repliegue y concentración al centro comercial y admistrativo de las islas como por inmigración del exterior hacia ellas. Fundamos estas apreciaciones en los da-

17. A.G.I., Filipinas 18: Carta de D. Santiago de Vera a S. M.; 13 de Julio de 1589. Para comparar el progreso de la edificación de piedra cfr. Antonio de Morga, Sucesos de las Islas Filipinas; $B \& R$, XVI 143.

18. Rojas a Felipe II, 30 de Junio de 1586: $B \& R$. VI, 268, 271.

19. Informe del Cabildo Secular de Manila al Gobernador; 15 de Febrero de 1591; $B \& R$, VII, 301-304: Benavides a Felipe III: 5 de junio de 1603: Ibid., XII, 101; A.G.I., Filipinas 18: Cabildo Secular al Rey: 13 de junio de 1589 donde se dice que por el establecimiento de la Audiencia y lo que su gasto importa en encomiendas, los vecinos han quedado sin posibilidad de retribución, y."han desmayado tanto que perdidas las esperanzas de verse remediados procuran por todas las vias que pueden salir huyendo de esta tierra". 
tos suministrados por la "Relación punctual de las encomiendas que ay en la ysla de Luzon y las demas yslas Philipinas... a postrero de mayo de mill y quinientos y noventa y un año" ${ }^{20}$. He aquí los aspectos demográficos de más subido interés para nuestro propósito:

"Tiene esta ciudad cosa de trescientos vezinos... Ay de ordinario dozientos soldados que tiran paga con sus oficiales...".

Por lo que respecta a los demás establecimientos españoles de las islas, la Relación nos da el siguiente recuento:

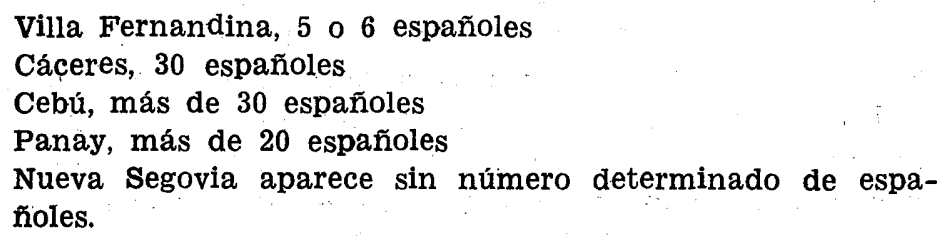

Comparando estos datos con los ya conocidos de la "Listas de gente y armas" de D. Diego Ronquillo y la documentación coetánea advertimos que mientras Manila ha experimentado un crecimiento cuasi expectacular, de 80 vecinos a unos 300 , los establecimientos provinciales han sufrido un significativo descenso de población: Arévalo (Panay) ha partido unos 45 hombres; Cebú unos 30 ; Cáceres 39 y de los 97 que se daban como existentes en Nueva Segovia no se nos suministran datos, pero puede concebirse un descenso proporcional. La Villa Fernandina de Vigan ha bajado de 19, a 6 cuando más. No pretendemos decir que las bajas de los establecimientos provinciales sean precisamente las alzas experimentadas en el asiento de vecinos en la capital, pues los españoles en las islas se extinguian por décadas en una cantidad indeterminada que más adelante intentaremos de establecer en proyección estadística. Lo que ocurre es que la imigración externa tiende a gravitar más pronunciadamente al centro vital del archipiélago en detrimento de los establecimientos periféricos (razón económica), y en beneficio de la indispensable concentración defensiva (imperativo estratégico).

Habrían de añadirse aquí los testimonios de las listas de vecinos encomendados y sin encomendar que pertenecen cronológica-

20. RETANA, Archivo, IV, 41-43. 
mente al final de esta década, pero prescindimos de ellas de momento, pues son meramente corroborativas y su material más apto para presentarlas en nuestro posterior análisis cualitativo de la población de las islas.

Se completa así el recuento de población en Manila y las islas hasta el final del siglo XVI. El XVII se abre con la rebelión china y se continúa con la continua presión holandesa en los mares y sobre las costas del Archipiélago. Estos dos factores, entre otros, provocan una prolongada crisis económica con fatales resultados para la población de españoles y naturales. El levantamiento de los chinos en 1603 puso la existencia de la colonia española literalmente entre la espada y la pared; en la confusión y la indecisión de la defensa y reducción de los sublevados aquel puñado de españoles hubo de sentirse destinado a desaparecer; quizá por ello el empeño en la victoria se sintió hasta individualmente como una irrenunciable exigencia, pero desde luego que el triunfo no hubiese sido posible sin el apoyo de los naturales filipinos que entonces, como en todas las ocasiones de verdadero peligro, lucharon denodadamente en hermandad de armas y de sangre al lado de los españoles.

Restaurada la normalidad y desarticulada la rebelión, informa el Ayuntamiento de Manila a S. M. sobre las causas y la ocasión del alzamiento, acusando a la Audiencia de haber sido muy libérrima en la concesión de permisos de estancia a los chinos por beneficio de los propios Oidores y sus familiares y deudos, proporcionándonos a la vez el pertinente y preciso dato demográfico:

\begin{abstract}
"De esta manera y por estos caminos y modos se bino a sangleyes, y con la ocasión que les dio de dexar tanta gente junta en tierra donde no avia ni aun dos mill doscientos españoles y de presente en la ciudad setecientos entre hallar la tierra este año de seiscientos tres con veynte mill vezinos y soldados, trataron de alzarse con la tierra y hazer Rey de ella a un Thomas Bautista de Vera sangley Xpiano" 21.
\end{abstract}

De ese número escaso, "iendo en seguimiento de los Sangleyes murieron doscientos y cinquenta o tresciento de ellos (caballeros y saldados)" ${ }^{22}$ y Manila no pudo ya recobrarse, a pesar de las conti-

21. A.G.I., Filipinas 27: "Cabildo Secular a S. M., Manila, 6 de Diciembre te 1603; también en COLIN-PASTELLS, Labor evangélica II, 423.

22. Parecer del Oidor Don Juan Manuel de la Vega: COLIN-PASTELLS, Labor evangélica, III, 606. 
nuas cebas de gente, de su número tope de 300 vecinos en la mejor época del siglo anterior.

A 12 de enero de 1616, con ocasión de la salida de Don Juan de Silva a la búsqueda y ataque de la escuadra holandesa, en contravención de la letra de la cédula de $\mathbf{S}$. $\mathrm{M}$. de 30 de diciembre de 1614 celebrose en Manila Junta General. El Oidor Don Juan Manuel de la Vega escribió entonces un parecer adverso a la salida de Silva, fundándose, entre otras razones, en el desguarecimiento de la ciudad, expuesta a un ataque de sorpresa. Da estos datos sobre el explosivo complejo social en que se movia la reducida colonia española:

“...Mas de treinta mil enemigos conocidos... tiene dentro y fuera (la Ciudad), porque al presente avia mas de doce mil Sangleyes y a la venida de las naos de China... se juntaran veynte y quatro mil y mas... Dentro de la ciudad quedaban esclavos y criados naturales enemigos no excusados en nuestras mismas casas siete $u$ ocho mil que serian los enemigos mas ciertos aviendo lebantamiento de los sangleyes... Que de los españoles que quedaban en esta ciudad con los recogidos de los vecinos de las yslas y extravagantes por lista no havia mas de setecientos y cincuenta con todos los mozos desde diez y seis años, biejos, enfermos y manos inutiles para cualquier ocasión... Avia por cada español mas de cuarenta enemigos, cuando mas si en realidad de verdad no quedaban trescientos utiles. $Y$ que este peligro acrecentaba porque si estos naturales que estan tan irritados y bejados... se aunasen con los de arriba, avria por cada uno mas de mil..." 23 .

D. Rodrigo de Vivero escribía el Rey en 1608:

"Suplico a V.M. humildemente considere la necesidad que esta $\mathrm{S}$ islas tienen de ser socorridas de dineros $\mathrm{y}$ gentes; porque en todas ellas, segun he sabido, no hay 1800 españoles; y aunque las fuerzas de ellos juntos se pusiesen a cualquier defensa, estan derramadas y por esta razon flacas, porque unos estan el Maluco, otros en Pintados, otros en la Prova. de Cagayan y Cebú y los demas en Manila" 24.

Por lo que respecta a dineros, el nuevo Gobernador informa

23. COLIN-PASTELLS, Labor evangélica, III, 605.

24. A.G.I., Filipinas. 7: Rodrigo de Vivero a S.M.: Manila 8 de Julio de 1608. Cf. P. PASTELLS, Historia general de las Islas Filipinas VI (Barcelona, 1925) XXVII-XXVIII. 
que los atrasos de la Real Caja son ya exorbitantes, pues los derechos reales no pasan de $\mathbf{8 0 , 0 0 0}$ pesos y los gastos sólo en Filipinas montan 130,000 más los 120,000 a que ascienden los del Maluco. La deuda acumulada de la Hacienda Real en las islas a estas fechas era de 200,000 pesos. Termina suplicando se manden al año no menos de cuatrocientos hombres para atender a las necesidades de población y defensa ${ }^{25}$.

En la década de los veinte tenemos para Manila exactos cómputos demográficos debidos al informe del Arzobispo Agustino Fray Miguel García Serrano:

"Dentro de las murallas de Manila no hay mas que una parroquia de españoles..." En ella "se administran 2.400 españoles de confesion hombres y mujeres en que entran algunos mestizos: los mil varones vecinos y extravagantes; y los 816 soldados de paga; los 584 restantes son mujeres; en este numero no entran los Religiosos, sacerdotes ni niños...". "En el pueblo de Bagumbaya... (en) la parroquia de Santiago se administran 150 españoles, 150 mestizos y 400 indios esclavos" 26 .

El censo notarial de 1634 que analizamos extensamente más tarde en el estudio cualitativo de la población de la ciudad presenta en total un asiento de 283 vecinos y nos cuesta llegar a mediados de siglo para encontrar un ligero avance, sin duda pasajero, en la cifra de vecinos de Manila ${ }^{27}$.

Un rápido descenso y una pronunciada decadencia son las tónica de la segunda mitad del siglo XVII para las islas en general y para la capital en especial. Manila se ve casi imposibilitada de mantener su vida ciudadana, reducida a la exigua cifra de 30 vecinos. El Ayuntamiento está a punto de extinguirse: no hay Regidores perpetuos y en las últimas décadas queda reducido el Cabildo a tres capitulares interinos sin posibilidad de actuar, a menos que se amplíe el número a seis. El consejo insiste en que se pongan a la venta por pregón las regidurías vacantes, pero se contesta que por más de cuarenta años nadie solicita ni paga un céntimo por ellas, pues no reportan más que disgustos sin la más mínima com-

25. Cf. P. PASTELLS, Historia general de las Islas Filipinas VI (Barcelona, 1925) XXVII-XXVIII.

26. A.G.I., Filipinas 74: Arzobispo Serrano a S. M.; Manila 21 de Junio de 1622 ; P. PASTELLS, Historia general, VII, LXXV-LXXVI.

27. A.G.I., Filipinas 27. Véase Suplemento documental. 
pensación ${ }^{28}$. La correspondencia con su Magestad y el Consejo es deprimente desde 1655 a 1668 lo mismo al nivel particular que al oficial: este último año informa la Audiencia que una extendida epidemia ha asolado las islas costando la vida a más de 50,000 naturales y a un número de españoles ${ }^{29}$, los cuales no llegaban, según otra referencia coetánea, a los 300 en todas las islas ${ }^{30}$. Situación que es evidente no había cambiado desde que el Ayuntamiento la describía ya asi diez años antes:

"La poblason que ha quedado de vezinos en esta ciudad es tan corta que no llegan a treinta por averse muerto $\mathrm{y}$ aver muchos años que no vienen de esos Reynos ni de los de la nueva España ninguno como parece por los que estan en la matricula de esta ciudad por donde se vera el miserable estado en que queda y la dejaron sus rruinas, y asi como un cuerpo necesita del sustento para su alimento, asi esta republica que en los ultimos alientos se halla pide para poder vivir el que requiere de personas que la haviten y de nuevo pueblen este reyno; y pues $\mathrm{V}$. magd. es tan padre como rey de sus leales vasallos, como tales y como hijos pedimos el remedio a sus pies con el rendimiento y humildad que debe a su grandeza" ${ }^{31}$.

Desde casi el comienzo de este siglo la persistente lucha en el

28. A.G.I., Filipinas 28: Los datos contenidos en este párrafo proceden de los documentos 406,407 y 408, más los resúmenes de correspondencia contenidos en el mismo legajo. Las causas de la decadencia se inician y se deben a las estricciones de Quiroga sobre el comercio; a la presión holandesa; a la rebelión china con la destrucción y abandono del Parián y la consecuente ausencia de los champanes Sangleyes y a la reducción de población española. Los informes del Arzobispo y el Cabildo Éclesiástico (24 de junio de 1668), de los Agustinos (20 de Junio), Provincial de los Dominicos (27 de Junio); El Gobernador Manuel de León (15 de Junio, 1670) remite informe de los oficiales Reales sobre el estado decadente de la Hacienda: el importe de los sueldos de cada año montan 445.530 pesos y los 200.000 que se solicitan no llegarán a cubrir la mitad de esos gastos. Sabiniano Manrique de Lara (20 de julio 1661) dice ha tenido que pedir un empréstito al Comercio por valor de 66.502 pesos para socorrer a los indios y otras urgentes necesidades. El gasto de las Islas importaba 664.000 pesos "y los efectos que hay para ello no alcanzan a 100.000 pesos".

Los Oficiales Reales ( 3 de junio, $1671-n .^{\circ} 243$ de los Indices- resumenes) que la Real Caja está con empeños de más de 4 millones de pesos; que no se paga el Cabildo Eclesiástico, Religiones, los sueldos de la Real Contaduría y los jornales de los naturales. 500.000 pesos escasos montan los efectos, que las Cajas Reales cobran en la tierra y "no llegan a cien mil pesos al año los que se han remitido en Mexico en reales de 40 años a esta parte regulado uno con otro".

29. A.G.I., Filipinas 28: Audiencia a S.M.: 27 de junio de 1668.

30. A.G.I., Filipinas 28: Arzobispo y Cabildo Eclesiástico a S. M. ; 24 de Junio, 1668.

31. A.G.I., Filipinas 28: Cabildo Secular a S.M.: 15 de Julio de 1658. 
mar contra Holanda, las severidades de D. Pedro de Quiroga con el comercio de las naos, la retención de capitales en México, la desconfianza y el absentismo de los champanes de China, la escasez de situados remitidos a las islas, la segunda seria rebelión de los Sangleyes y el terremoto de 1645 fueron apretando el dogal al cuello de la colonia que cada vez más se veía obligada para sobrevivir a echar nuevas cargas e imposiciones sobre la población de los naturales ${ }^{32}$. La escasez de población, provocada por el ningún atractivo económico, revertía entre otras cosas en una casi total ausencia de pilotos expertos en la conducción de galeones que irremisiblemente se perdían cuando de tarde en tarde intentaban casi desesperadamente una salida, agravando de ese modo la situación económica que se intentaba remediar. Casi todos estos extremos quedan apuntados en la carta del Cabildo citada de 1658, asi como en las comunicaciones de todo orden remitidas al gobierno central casi hasta el final de siglo ${ }^{33}$.

Un relativo desahogo, pero muy relativo, sobrevino en el siglo XVIII. Daremos para esta centuria unas breves y comprensivas referencias demográficas que nos ayuden a formar idea del incremento poblador; en aras de la concisión sacrificaremos gustosos una multitud de notas para dar solamente la situación de la demografía española en el cuarto final del siglo.

De una serie de consultas del Consejo Indias y Juntas especiales sobre los intentos de revitalización económica de las Islas salió, entre otras medidas, la creación del Consulado por Real Orden de 18 de diciembre de 1769. Entre los papeles sometidos al estudio del Consejo figuran los dos famosos manuscritos de D. Leandro de Viana, apostillados por Salgado, bien conocidos ambos por los estudiosos de los esquemas económicos propuestos para el Archipiélago, en substitución del galeón de Acapulco. El mismo Viana, ya Conde de Tepa y miembro del Consejo, presentó un extenso escrito en que

32. La desolación causada en Manila por los terremotos, con el de 1645, quedan trágicamente descritos en los cronistas de la época: de las edificaciones de Manila "que costeaba (antes) tan grandes edificios"-dice el P. Casimiro Díazunas se arruinaron en estos temblores y otras en los de 20 de Agosto de 1658 que acabaron de borrar de la faz de la tierra las reliquias de la antigua ciudad, quedando hasta hoy despobladas sus calles, sin que por lo mucho que se ha fabricado haya vuelto a mediano estado en comparación de lo que ha sido". "Las personas de calidad que perecieron esta noche fueron algunos centenares. y los plebeyos pobres y gente dela tierra muchos, aunque el número no ha llegado fijamente a mi noticia. Algunos dicen llegaron a seiscientos los muertos, pero ocho solos los vecinos de nombre y dos Religiosos" (C. DIAZ, Conquistas de las Islas Filipinas, II, Valladolid 1890, 478-479).

33. Cfr. notas 28 y 31 . 
analiza las vicisitudes del permiso de comercio con Nueva España y los escasísimos o más que nulos resultados de su largo ejercicio, para terminar proponiendo las bases del Consulado, que tras ser recomendadas por la Junta especial, pasaron casi sin modificación al decreto original de creación. De este escrito expositorio tomamos estos datos:

"En lo antiguo se contaban cinco o seis ciudades pobladas de españoles con alguna consideración... Hoy solo se habla de Manila, en la que parece que al paso que se ha ido aumentando el permiso de Comercio de Acapulco ha ido bajando su población y vecindario, pues pintandose en lo antiguo, tan magnifica, poblada y opulenta (?), en el año 1724 con el esfuerzo de querer la misma ciudad probar el aumento de su vecindario para que se le extendiese el permiso, a lo mas que pudo subirle fue a 882 vecinos, formadas las justificaciones a su arbitrio y sin contradicción: y hoy (1769) se demuestra que aun es mucho menor" ${ }^{33}$.

Mucho menor era ya, desde luego, en 1756, pues el Gobernador Marqués de Ovando por esa fecha comunicaba:

"Los españoles habitantes en estas islas son tan pocos que uniendolos todos $\mathrm{y}$ de todas partes apenas podran hacer mil hombres y los mas de ellos inabiles e incapaces (buen dechado es el Cabildo de Manila)... Si bienen razonables, se aburren, se vuelven o se mueren tristemente, y asi vienen a estar oy estas islas en esta parte; cuasi tan a los principios que sin exageración tienen muchos menos que los que las historias nos refieren de su primitiva conquista" ${ }^{35}$.

La negativa de exageración en las apreciaciones del Marqués es, como ocurre casi siempre en que la salvedad se usa, prueba casi fehaciente de ella. En 1788 el Provincial de Santo Domingo, Nicolas Cora, escribía a Berenguer de Marquina:

"Podre informar lo que consta de noticias publicas haber en estas islas 250,000 tributos que regulados a 5 personas

34. A.G.I., Ultramar 516: El escrito, con dos róricas, está fechado en Madrid a 24 de Agosto de 1769.

35. A.G.I., Filipinas 387: Ovando al Marqués de la Emsenada: Manila, 16 de Julio de 1756. 
cada uno componen el numero de 1,250,000 almas): De los españoles dice: "No se que lleguen a dos mil". ${ }^{36}$.

De un informe de la Real Compañia de Filipinas, ya en los últimos años del siglo, entresacamos este testimonio:

"La ciudad de Manila, ventajosamente situada en un puerto excelente, circundada de terrenos fertiles y de facil navegacion interior, privilegiada con un comercio exclusivo, absorviendose de dos siglos a esta parte los tesoros de la Nueva España y los situados cuantiosos que constantemente ha recibido, se halla reducida a 800 vecinos de todas castas y entre ellos a unas cincuenta familias de verdaderos vecinos españoles" ${ }^{37}$.

Aceptamos, pues, la cifra de 800 vecinos para Manila, como la más definitiva en la letra de los testimonios contemporáneos, ya casi en el dintel del siglo XIX, y anotamos ya la heterogeneidad de esa población. Hemos de observar también, a partir del último cuarto de siglo XVIII una más abundante distribución periférica en el asentamiento de españoles en las islas, matiz que percibimos al estudiar los planes generales de tributos y almas que administran las órdenes religiosas y el clero secular; por su indudable interés para la historia documentada del siempre necesariamente limitado criollismo y mestizaje español, extractaremos algunas cifras demográficas.

Los planes de población de 1787 acusan la presencia de españoles en las provincias y poblaciones siguientes:

Nueva Segovia (Cagayan): Españoles, 103; mozos y mozas, 8; muchachos, 12; niños, 21.

Bigan (Ilocos): Españoles, 144; mozos, 33; muchachos, 49; ninos, 68.

Santo Domingo (Ilocos): Españoles, 74 ; mozos, 14; muchachos, 6; niños, 14.

Bantay (Ilocos) Españoles, 24; mozos, 31; muchachos, 12; niffos, 19.

Magsingal (Ilocos): Españoles, 8; mozos, 8; muchachos, 4; niños, 8.

36. A.G.I., Ultramar 519: El Provincial de Sto. Domingo al Gobernador; 7 de Septiembre de 1788.

37. A.G.I., Ultramar 519: Exposición de la Real Compañía en la controversia con el Consulado de Manila. 
Lingayen (Pangasinan): Españoles, 68; mozos; 18; muchachos, 18; niños, 30.

Calasiao (Pangasinan): Españoles, 22 ; mozos, 7 ; muchachos, 8 ; niños, 13.

La exposición precedente nos da un total agregado de 443 españoles mayores de edad asentados en solo siete poblaciones de las tres provincias con un número global de 293,446 almas radicadas en 89 establecimientos, sin contar los territorios de misiones de Ituy y Paniqui ${ }^{38}$.

De la población total de almas del Obispado de Nueva Cáceres comprendiendo las Provincias de Camarines, Albay, Tayabas y la Misión de Baler que se da como $169.263,34$ son españoles europeos; 16 criollos y 789 mestizos de español, contra 426 mestizos chinos. Albay con 192 mestizos españoles y Malinao con 87 van a la cabeza, seguidas de Tabaco con 80, Sta. Cruz con 64 y Tabuco con 58. 85 alumnos estudian clases superiores en la capital del Obispado; reciben escolaridad regular 14,593 niños y niñas ${ }^{39}$.

La Orden Franciscana administraba al final del siglo XVIIr 249,472 almas en 86 poblaciones distribuidas en siete provincias: Tondo, Bulacan, Laguna de Bay, Tayabas, Batangas ( solo San Pablo), Camarines y Samar. En Tondo tienen alguna población españolas. Dilao: 148, Santa Ana: 19, Sampaloc: 34, y San Miguel: 45, para un total provincial de 246.

En Bulacan hay españoles en Bocavi (s): 75, Sta. Maria: 6, Meycauayan; 17, Marilao: 12, y Polo: 8 que dan un total de 118.

En Laguna, el total provincial es de 42 , distribuidos así: Mavitac, 2; Pagsanghan, 18 sta. Cruz, 16; y Pila, 6.

No hay población española en San Pablo de Batangas.

En Camarines, Naga cuenta 28 españoles; Milavor, 1; Bao, 4;

38. A.G.I., Ultramar 519: Planes de almas, remitidos al Gobernador Marquina: 11 de Agosto de 1788.

39. A.G.I., Ultramar 519: Resulta interesante comparar este plano demográfico de la diócesis de Nueva Cáceres con el de 1801, sometido por el Obispo Domingo Collantes. Los españoles en la misma jurisdicción son 28, habiendo bajado 6 del número anterior, lo que representa un $17 \%$ de descenso. Los criollos han aumentado en 4 , igual a un $25 \%$. Los metizos españoles son ahora 1.087, un aumento de 298 , equivalente a un $37 \%$ y más sobre la cifra anterior. El total de almas ha experimentado un incremento de 37.144, equivalente a un desarrollo demográfico general para las provincias de la diócesis de un $22,54 \%$ sobre la cifra de 1788. Estos datos comparativos los sacamos de la obra de nuestro recientemente desaparecido inspirador y amigo, Domingo Abella, Bikol Annals: A. Collection of Vignettes of Philippine History, I (Manila 1954), 152-153. 
Nabua, 1; Polanqui, 11; Oas, 4; Guinobatan, 1; Camarines, 23; Cagsava, 2; total 75.

Toda la provincia de Tayabas reúne la población española en Mauban, y son 191 almas. Sólo, pues, 24 poblaciones entre las 86 más doce misiones, contaban con alguna población española en las provincias señaladas en Luzón y solo un total de 737 "españoles y -mestizos de ellos de todos sexos y estados inclusos los párvulos", como literalmente reza la casilla en que aparecen estas cifras ${ }^{40}$, se hallaban diluídos en el mar de la total población de 249.472.

\section{IJI. ANALISIS CUALITATIVO DE LA POBLACION}

\section{La población en función de la economía}

Una de las visiones más desesperanzadas y deprimentes de las Filipinas y su posibilidad económica la debemos a la pluma erudita de Don Sancho Díaz de Ceballos, gentilhombre de cámara del Virrey de Nueva España, llegado a las Islas en Julio de 1575, poco después del ataque de Limahon. Traía misión especial del Virrey para informar sobre la tierra, y dio cumplimiento a esa misión en una carta en que recogió el fruto de sus observaciones, datada el 4 de junio de 1576. Las noticias que tenemos sobre el personaje proceden casi todas del análisis interno de la carta: era, desde luego, de una cultura vastísima y un fino observador, uno de los pocos ejemplos del soldado intelectual de la clase aquella que manejaba "ora la pluma, ora la espada"; hubo de tener suficientes conocimientos de arquitectura, ya que en mérito a los mismos Sande le encomendó el estudio y diseño ae un nuevo emplazamiento de la Ciudad "quinien. tos pasos mas el rio arriba de donde ahora esta". Sobre este proyecto comenta Ceballos en donoso estilo y muy socarrona vena:

“...A todos parecio escogida cosa la traza que para ello se hizo, pero quisieran hallarla hecha conforme al modelo que yo dy y no meter las manos al trabajo, y asi por huirlo tomaron un medio narto afrentoso para ellos a quien tocaba mas que a mi, pues tienen los mas haziendas y mugeres y hijos, y no yo que careciendo de todo esto me tiene solo prendado el servir a mi Rey: el medio fue que cercaron de maderos sencillos como corral de ganado la ciu-

40. A.G.I., Ultramar 524: Plan general de tributos y almas que administra la Provincia de San Gregorio perteneciente al año de 1797. 
dad en el mesmo lugar donde se estaba. los cuales cada dia de si mesmos se caen, que ha dado harto aue reir a los huespedes Sangleyes que para todo estan despiertos" ${ }^{41}$.

Sirvió Caballos los puestos de Alcalde mayor de la Pampanga y de Batán con los repartimientos de Macabebe y Calompit, de los que dice "es la tierra de mas gente y mas fertil que hay en toda esta isla, o por mejor decir, que si esta faltase no hay en toda esta grandisima isla donde se puedan sustentar diez españoles".

Fue luego comisionado para el reconocimiento de las minas de la. provincia de Ygolot, para donde salió con cuarenta soldados y doscientos indios, y resume así los ruines resultados de su expedición; "no se saco ni medio grano de oro con haber descubierto mas de doscientos minas, sino mucho trabajo y lanzadas, y la tierra asperisima y casi inhabitable por no haber bastimentos y estar ochenta leguas de Manila" 2 .

Extractamos los párrafos más salientes de esta pobrísima impresión de Ceballos sobre las potencialidades económicas de las islas y el casi nulo incentivo que of cecian a la població española:

“...Las partes mediterraneas son esteriles y asperisimas, llenas de arcabucales, y en extremo es grande el calor y tan mal habitadas que "apparent rari nantes in gurgite "asto". Solo hay un cebo que entretiene los españoles que es un poco de oro que anda por la tierra que dentro de poco tiempo desaparecera del todo como ya ha desaparecido la mayor parte de lo que se via al principio que en esta tierra se entro. Todos los soldados que ay no llegan a trescientos hombres y estos repartidos por diversas partes $\mathrm{y}$ en diferentes yslas, de suerte que primero que se junten para ayudarse en alguna necesidad seran todos facilmente deshechos: y aun deste numero que he dicho los mas son soldados dobles porque tienen tantas soldaduras una sobre otra que no les queda sino jatarse cosas pasadas, y assi los que estan encomendados como los que no lo estan pasan gran miseria, porque a los mas de los encomendados les estan repartidos indios e yslas que jamas vieron y adonde

41. A.G.I., Filipinas 34: Sancho Días de Ceballos al Virrey de Nueva España: Manila, 4 de Junio de 1576.

42. A.G.I., Filipinas 34: A la vuelta de esta expedición encontró Díaz de Ceballos con su gente a los Padres Rada y Alburquerque abandonados y vejados por los Chinos con quienes habían confiado penetrar en el Celeste Imperio. Cf. Isacio RODRIGUEZ, Historia de la Provincia Agustiniana del Smo. Nombre de Jesús de Filipinas, vol. 1: Bibliografía (Manila 1965) 135. 
para cobrar los tributos seria menester mucha gente y mucha ventura: y la tierra esta tan por conquistar que hasta una legua desta ciudad se vienen por su pasatiempo los enemigos a matar los soldados y alanzearlos".

"...La tierra va siempre a menos, y el que aora un año tenia mill yndios, no tiene este año trescientos: todos los cien hombres. $Y$ si con todo esto se tuviera esperanza que su magd. de aqui a mil años hubiera algun provecho della todo era sufrible: mas aqui se ve claramente y V. Exa. lo tendra muy entendido por el effecto, que cada año se ha de gastar gran cantidad de dineros y hombres, y no buelven de retorno sino pleytos y embarazos harto impertinentes para tierra tan nueva y de tan poca gente: y el buen jugador suele levantarse con perdida de diez ducados para no venir a perder diez mill" ${ }^{43}$.

Nós interesa, de momento, no tanto la justeza objetiva de las apreciaciones expresadas sobre el mínimo incentivo económico de las islas, sino más bien las apreciaciones mismas, subjetivamente consideradas, y transmitidas por los navios de retorno que al remitir la correspondencia privada y pública del soldado y poblador decepcionado creaba para Filipinas una pobrísima propaganda de atracción y asiento de futuros pobladores. No hay duda de que esta clase de noticias de carácter decepcionante y negativo circulaban por Nueva España y llegaban a la Península ${ }^{44}$ y el efecto que tales noticias hacian como causas retardadoras de la esperada emigración es fácil de predecir, mas no ya tan fácil de calcular. Los efectos de esta mala propaganda de las islas como lugar de asiento aparecen expresados ya en carta del Virrey Martín Enriquez al Rey en 1573, en la que aluda a la rápida disminución del personal de la colonia por la inadaptación al clima y los sufrimientos de todo orden y declara que para substituir a los que hacen baja es preciso forzar

43. Véase referencia N.o 41. Una visión coincidente es la expresada en las palabras introductorias del Presidente en la Junta General de todos los Estados. a 20 de abril de $1586 \ldots$ "dixo que ya sabian la grande y estrema necesidad que en la tierra se padecia de causa de no haber en ella con que no se poder sustentar la gente española que en ella reside por ser la tierra pobre y nueva y no cultivada y las cosas della puestas en la policía que se requiere...": COLIN-PAS. TELLS, Labor evangélica, I, 333.

44. A.G.I., Patronato 24, Ramo 66: "Memorial General de todos los Estados...". En el Capítulo sexto leemos: "el 30 que procuran de huirse quento pueden ya por macan ya por maluco ya por malaca y por lo ordinario de la nueva españa con mil capas y achaques de que son casados enfermos o obligados a Religion y otras. El quarto que con esto tiene la tierra tan mala fama en Mexico y. en las demas partes de donde podrían venir que ningun hombre de valor sino muy pocos $\mathrm{y}$ viles $\mathrm{y}$ pobres $\mathrm{y}$ desarmados $\mathrm{y}$ inutiles o que casi no hacen al caso o seria mejor que no viniessen". 
a la gente a que se embarque para esta avanzada: del Oriente ${ }^{45}$. Las consecuencias de esta emigración forzada las habremos de ponderar muy pronto cuando hablemos de la clase de gente que arribaba a las Islas. La impresión subjetiva de los observadores y actores principales hubo de ejercer, pues, ese definitivo efecto negativo y retardador en la población española de las islas, que veremos enseguida reflejados en el asiento numérico de los censos y listas que luego analizamos.

En cuanto a la justeza objetiva de las observaciones de Ceballos, apuntamos simplemente que lo que él nos dice respecto a la flaqueza de la tierra, a la seguridad económica y social del español en ellas, a la insuficiencia y escasa rentabilidad de la encomienda, al gran indice de mortalidad de la población española, incluso su juicio desfavorable de esa misma población, lo encontramos corroborado, en substancia y contexto circunstancial, en otras fuentes coetáneas.

\section{El Fracaso de la Agricultura}

Cerrada para el español, por indisposición de talante y lo adverso de las condiciones climatógicas, la vía de la explotación agrícola, no le quedaba otra abierta para su subsistencia, como no fuera la merced real en alguna de las variadas formas que ésta vino a adoptar en Filipinas: la encomienda, el oficio público, o el comercio del galeón. La agricultura fracasó en sú principios, bien a pesar de significativos esfuerzos por activarla: Del Capítulo $4 .^{\circ}$ de las resoluciones adoptadas en el Memorial general de todos los estados de las Islas Philipinas sobre las cosas de ellas para su magestad, bajo el epígrafe: "De otras cosas de las quales depende la fundación y augmento desta Republica y Reyno", los siete primeros puntos aprobados versan sobre otros tantos medios de un plan de instaurar la explotación de los recursos agropecuarios del Archipiélago. que

El primer acuerdo establece la situación de hecho, declarando

“...hasta agora esta tierra no tiene ningunos fundamentos de labranzas ni granjas ni crianzas de ganados y de todo lo demas qua sustenta y engruessa la tierra, sino que los principios se fueron en conquistar lo poco que ay y despues se pasaron todos los pensamientos y cuidados a la

45. El Virrey Martín Enriquez a S. M.: México, 5 de Diciembre de 1573. En B\&R, III, $211 ; 212 ; 216$. 
mercancia y ganancia y ansi se esta todr inculto y sin asiento y que esmenester que de veras se procure que lo tenga, para lo qual su magd. vaya embiando cada año de Castilla o de la nueva españa siquiera ocho o diez labradores casados y con hijas, y para que vengan y asienten su magd. les haga la costa y aca les ponga casa y apero y otros favores, mandandolo ansi muy en particular, y que se refiera como ay tanta y tan fertil tierra y abundancia de madera y hierro y oficiales y mucha caça y lo demas necesario a labradores" ${ }^{46}$.

Los puntos siguientes de este notable documento piden exenciones y libertades de diezmos, pechos y servicios para los futuros pobladores y los naturales que les ayuden, estableciendo especificamente el punto $5 .^{\circ}$ :

"Que se mande a los principales y timaguas Indios que se acompañen con nros. labradores con justos conciertos y particion para que se aficionen $\mathrm{y}$ aprendan la labranza a nro. uso y los Españoles tengan quien les ayude con gente y otras cosas, que estos yndios son ladinos y sabran tener sus quentas con los labradores, principalmente si fuerer. llanos, como esta dicho" ${ }^{47}$.

Se ocupa el punto sexto de la recría del ganado de labranza, co . mo auxiliar indispensable para la promoción agrícola, pidiendo al Rey "que mande con fuerza lo que aca se a intentado". En incisu entrecomillado se refiere, sin duda, a meritorios esfuerzos de recría ganadera que los españoles en las islas procuraron desde los principios, con caballos principalmente japoneses y chinos. A este respecto, tenemos documentado el acontecimiento —pues ni más ni menos así aparece en nuestras fuentes- de la llegada a Manila de la que muy probablemente fue la primera yegua de las islas:

"Este año han venido a esta Ysla de las demas comarcanas catorce navios chinos con las mercaderias que acostumbran traer; a esta ciudad llegaron tres de ellos y traxeron una yegua al Capitan Juan Pacheco Maldonado que el año pasado la avia pagado; dio contento a esta Repu. blica" ${ }^{18}$.

46. Referencia de signatura en nota 44.

47. Referencia de signatura en nota 44.

48. A.G.I., Patronato 24, Ramo 28: "Relación de lo sucedido desde lo de julio de 1573 que es del dia que salieron de Manila los dos navios nombrados 
La proposición séptima de las aprobadas como recomendación a la Corona, y que hubiese por sí sola acrecentado notablemente el naciente interés y limitados logros en la explotación agricola, pretendía unir la encomienda al desarrollo de la agricultura:

\begin{abstract}
"Que mande su magd. que de aqui adelante las encomiendas se den con esta condición y carga de que el encomendero labre algun pedaço y haga labrar y acomode a los yndios y españoles dichos y que los Governadores cargen(s) la mano en esto $\mathrm{y}$ que se obligen(s) a tanta cantidad de Yuntas o de tierra o de fructos por si o con estos Principales y labradores dichos" ${ }^{49}$.
\end{abstract}

Si esta política aquí esbozada se hubiese llevado a la práctica ron esfuerzo permanente, no cabe duda que la agricultura en las islas hubiese pronto entrado con pie derecho y hubiese rendido los esperados frutos, al establecer, como lo hacia, hasta cuotas minimas de producción junto con la radicación del encomendero al territorio de su encomienda. Sin embargo, venturosa o desgraciadamente no fue así por una serie de razones, entre las que destacamos la desinclinación natural del encomendero a "destripar cabones", la adversa influencia del clima y la prescripción legal de que el encomendero no residiese dentro cie los límites de su encomienda. Ya otros autores han comentado que esta medida protectora de la ley, al mismo tiempo que protegió al nativo encomendado contra las explotaciones previsibles del encomendero e impidió en el archipiélago la evolución de la encomienda a la hacienda y al gran latifundio privado, tuvo también el inevitable efecto de retardar el desarrollo agrícola en proporciones incalculables. Añádase a todo esto el tentador señuelo de las inversiones de la encomienda en el lucrativo comercio de Acapulco que el encomendero tenía a mano dentro de la sociedad cerrada, exclusivista y cómoda de Manila donde sin pasar excesivos sudores podía, si bien con crecidos riesgos, multiplicar su capital, y tendremos el cuadro comprensible de lo que tal medida ilignificó.

El memorial de todos los estados, encomendado al P. Alonso Sánchez, surtió, según creemos, efectos muy favorables en los años consecutivos a su gestión, y los resultados no fueron permanentes,

Sanctiago y espiritu Sancto en los quales se embio razon de lo notable que hubo hasta aquel punto". Sin firma; está fechada en Manila a xvi de julio de 1574 .

49. Véase referencia 44 . 
porque tampoco lo fue la política agraria ni la atención de la Corona y los Gobernadores hacia ella. En respuesta a la petición de familias labradoras, se encargó al Maestre de Campo Diego Ronquillo de Peñalosa la organización de una expedición de cien familias de casados en 1590, aunque la renuncia natural del español emigrante a dedicarse al trabajo rural creó extraordinarias dificultades de reclutamiento y la mala suerte de aquel viaje terminó por reducir los labradores a una mínima fracción del número original ${ }^{50}$. En cuanto a la recría ganadera, de las variedades vacuna y caballar, se ordenó el envío de doce yeguas y dos caballos, veinticuatro vacas y dos toros ${ }^{51}$ y nos sorprende encontrar una referencia en la parte expositiva de una Cédula Real de 1609, según la cual había en el contorno de Manila "mas de veinticuatro estancias de ganado mayor que algunas ay de mas de cuatro mil (cabezas); y que como el numero es tan grande, se extienden mucho y se salen de sus limites con daño de los naturales". Se pide por el Rey a la Audiencia y al Gobernador pongan remedio "pues para el sustento necesario no son menester tantas estancias" 52

En la práctica, pues, en adelante parece ser que la política gubernamental en materia de explotación agricola fue la de deprimirla al nivel de lo requerido "para el sustento necesario". No es en absoluto paradójico que fuesen las Ordenes Religiosas la principal clase social de Filipinas que en cierta amplitud cultivó la tierra durante los siglos XVI al XIX, pues eran los Religiosos los únicos elementos de población española en quienes concurrian las dos condiciones más adecuadas para estimularla, es a saber: la radicación en el terreno cultivable y la exclusión corporativa de los beneficios del comercio de Acapulco. Esta es, a nuestro entender, la génesis verdadera de los famosos friar lands que tanta tinta inútil han consumido en la historiografía filipina de lo que va de siglo.

Le quedaban solamente al poblador y vecino, como medios de

50. Los documentos pertinentes sobre el fracaso de la expedición de familias labradoras pueden verse reproducidos en COLIN PASTELLS, Labor evangélica, II, 681-682.

51. Así se mandó en las Instrucciones de gobierno a Dasmariñas fechas en S. Lorenzo a 9 de Agosto de 1589, pero diez años más tarde informaba el Gobernador Francisco Tello que ni los labradores ni las vacas ni caballos habían llegado. Las instrucciones a Dasmariñas estan publicadas en Colín-Pastells, Labor evangélica, III, 741-750; los puntos 22-25 dan respuesta a lo propuesto por la Junta de todos los estados en relación con la agricultura) p. 745). La carta aludida del Gobernador Tello, fechada en 12 de Julio de 1599, es de signatura A.G.I., Filipinas 6: aparece publicada en traducción al inglés en $B \& R, X, 245-272$.

52. A.G.I., Filipinas 329. La R. C. está fechada en Segovia a 8 de Agosto de 1609. 
subsistencia o de riqueza, la encomienda, el comercio del galeón y el servicio público militar o civil; todos ellos, hemos ya observado antes, son variedades de la omnimoda merced real y de ella hace depender el Memorial de Grau y Monfalcón en el segundo cuarto del siglo XVII la pervivencia y presencia de los 3336 españoles de esta avanzada imperial en el Oriente, incluidos los religiosos ${ }^{53}$. Examinemos ya lo que significaba para la economía de los agraciados la consecución de cada una de esas mercedes.

\section{Potencial económico de la Encomienda}

Las listas de Don Francisco Tello, preparadas para el examen del Consejo y de su Magestad al final del siglo XVI, nos dan un agregado consolidado de 178 sujetos sobre los cuales podemos instituir un sondeo estadístico que nos permita ver, el número y medida, de ese potencial económico. El total de personas encomendadas en las cuatro jurisdicciones de Cebu, Panay, Nueva Cáceres y Manila es de ochenta y dos que representan el $46.06 \%$ de los 178 vecinos de las islas. Los 82 encomenderos se distribuyen así por situación económica: 29 de ese total de 82 son ricos, 37 tienen un moderado pasar, y 17 son declaradamente pobres; en la escala de porcentages esto equivale a $35.36 \%$ ricos, $45.12 \%$ con pasable desahogo, y $20.73 \%$ pobres. Analizada la situación económica de los 30 encomenderos de Manila, encontramos que curiosamente se distribuyen en tres partes iguales: 10 ricos, diez moderados y 10 pobres o un $33.33 \%$ en cada nivel del clasificación.

La encomienda, pues, al menos en el contexto circunstancial a que se refieren estos datos, no ofrecia de por sí seguridad económica. Pero todavia hay más, y el potencial económico de la encomienda aparece aun más marcadamente reducido si añadimos estas consideraciones: en Manila hay sólo diez personas calificadas de ricas entre los 30 encomenderos, y ninguna de las diez dependia exclusivamente de la encomienda para lograr ese desahogo económico.

Por número de tributarios, las encomiendas de Manila se distribuyen así:

a) Hay 12 encomenderos con encomiendas de menos de mil tri-

53. Memorial de Grau y Monfalcón, Procurador de la Ciudad de Manila en la Corte de Madrid, incorporado en el Extracto historial del expediente que puede en el Consejo Real $Y$ Supremo de las Indias ainstancia de la Ciudad de Manila, $y$ demás de las Islas Phitipinas, etc., (Madrid, 1736). Extractado y traducido en $B \& R$, XXX, 23-109. 
butos, y de ellos ocho son pobres, tres ricos y uno de moderado pasar. Los ocho pobres lo son, al parecer, por no tener otras adehalas fuera de la encomienda; mientras que los cuatro que no lo son han dejado de serlo por añadir a la encomienda, ya las percepciones por razon de oficio o comercio, o las dos cosas juntamente.

b) Doce personas disfrutan de encomiendas con más de mil y hasta dos mil tributos. La calificación económica de estas es la siguiente: una pobre; siete medianas y cuatro ricas. Sólo tres de los siete encomenderos de economía pasable en esta clasificación dependen exclusivamente de su encomienda, y los demás, con los cuatro ricos del grupo, tienen otras fuentes de ingreso. Uno es calificadamente pobre, a pesar de su encomienda de mil ochocientos indios.

c) De dos mil tributos hay tres agraciados: uno calificado de pobre, y dos con la calificación de "tiene bien de comer" y "le queda bastante que comer".

d) Los dos encomenderos con encomiendas de un número de tributos superior a dos mil: el Mariscal Gabriel de Ribera, con tres encomiendas que agregadas cuentan más de 8000 tributos, y Juan de Zamudio, con más de 3500 , son ricos, aun sin tener en cuenta sus negocios y "otras inteligencias". Al Mariscal se le califica como "el mas rico en todas las islas". Una de los treinta encomenderos de Manila aparece en la lista sin determinación del número de tributos de su encomienda.

La insuficiencia casi general de la encomienda de hasta mil tributarios es clara y evidente, y plenamente justifica la modestia de la petición elevada al Rey en el Memorial de todos los estados en 1586 de que "las encomiendas no se provean menores de ochocientos o mil yndios porque aia para la doctrina diezmos y otros gastos que en la encomienda de quinientos tributos no se pueden hacer..." "54. Como se ha vista, aun la encomienda de más de mil tributos dejaba en la fecha de nuestras listas muy poco para gastos de cualquier naturaleza. Pasamos por alto otros factores que reducian todavia más el valor de la encomienda como apoyo económico, tales como la escalada de los precios, y las restricciones de la autoridad eclesiástica para la justificación del cobro del tributo entero de ocho reales so pena de perder la eterna salvación si no restituián,

54. A.G.I., Patronato 24, Ramo 66. 
lo cual hace decir amargamente a Sancho Diaz de Ceballos: "y esta es otra miseria desta tierra que viven sin vivir, y al fin creo que se viene a llevar el anima el demonio y la ropa el señor antonio"55.

Hay que tener en cuenta, a pesar de todas las limitaciones expresadas, que la encomienda era la base más sólida del apoyo económico del español benemérito en las islas, y como tal, la más ambicionada y solicitada por todos los medios ${ }^{56}$. Su transmisión por herencia a varias vidas, de padres a nietos, la exponía constantemente al arribismo y manipulación de los despiertos. Al concederse por ley a los beneméritos en servicios, sobre todo militares, siempre tras largas probanzas, se encontraban los agraciados por lo general con gastada salud, mutilaciones y achaques al tiempo de serles confirmada la merced de la encomienda; revertía ésta en herencia, a la muerte del marido, en su viuda en los casos tan frecuentes de matrimonios estériles, y esto hacia de las ricas hembras, viudas encomenderas de Manila y la periferia, el más preciado partido de matrimonio con preferencia a las doncellas más apetitosas en otros respectos que no tenían ordinariamente más en su haber que sus hechuras y palmito. Los jóvenes, o no tan jóvenes donjuanes, que llegaban a estas playas con rápidas ganas de medrar, descubrieron pronto que una de las maneras más expeditivas de conseguir un difícil y relativo desahogo económico era hacerse "conquistador" de una, más o menos cascada viuda con una encomienda heredada de su anterior marido o maridos.

Lo dicho está amplísimamente confirmado por nuestro análisis sociológico de la encomienda: nótese, por ejemplo, que de los 30 va-

55. A.G.I., Filipinas 34 , en carta previamente citada.

56. Cada uno de los encomendados tributarios pagaba al año diez reales de tributo, dos para el Tesoro Real y ocho para el encomendero; cuatro se pagaban en especia -55 gantas de arroz (palay)_-; una gallina al valor de un real y los tres restantes en dinero. De esta percepción el encomendero había de pagar al ministro que proveía la "instrucción" a razón de cien pesos de ocho reales, cien fanegas de palay, y una arroba de vino para la celebración de la misa, por cada quinientos tributarios de administración espiritual. (A.G.I., Filipinas 7: Niño de Tábara a S. M., Cavite, 2 de Agosto de 1628). Este informe está publicado en $B \& R$ XXXII, 217-245.

Según el Memorial de Grau y Monfalcón de 1637, en 1630 el número de tributos en encomiendas de personas particulares era de 48.000 , a Grau razona que para los 230 vecinos de Manila - sin contar los otros trescientos españoles que viven en Cebú, Cáceres, Segovia y Arévalo- eso correspondería a 160 tributos por cada persona, (lo que no es precisamente exacto). Equivalen los 48.000 tributos al mismo número de pesos de a ocho reales - nos dice Grau- pues los dos adicionales son para la Corona. $\mathrm{Y}$ aun los ocho remanentes están gravados con tantas obligaciones que no le quedan al encomendero apenas seis reales. El Memorial en traducción inglesa, en $B \& R$, XXVII, 55-212; lo pertinente a nues tra cita, pp. 82-83 
rones que figuran en la lista de encomiendas de ciudadanos de Manila, 16. las tienen en propiedad y 14 por herencia; de los 30, la mitad (15) son casados, y de ellos once lo son viudas que aportaban en dote las encomiendas de sus anteriores maridos.

Catorce de las diecinueve encomiendas de Cebú han venido a sus actuales dueños por herencia, contra cinco poseídas en propiedad; 12 de los 19 encomenderos son casados, y de ellos seis lo son con viudas encomenderas. En Panay, de 16 encomiendas alistadas, hay 6 retenidas en propiedad, 10 por herencia; 8 de los encomenderos son casados, y de ellos 3 son con encomenderas viudas. Para Cáceres el recuento es: 8 encomiendas en propiedad, 9 heredadas; hay. 12 encomenderos casados, de éstos 4 con viudas encomenderas.

En resumen, de los 82 individuos que figuran en las listas del Gobernador Tello, agraciados con encomiendas, 47 (67.14\%) son casados, y de ellos $24(51.06 \%)$ lo son con viudas, algunas de ellas en tercera velación. No se registra un solo caso de un encomendero por derecho propio que haya elegido una viuda para su compañera de vida... Esta situación de "caza de encomiendas", censurada más de una vez por las autoridades de las islas ${ }^{57}$, podía ser un rápido método de asegurar una estabilidad económica $o$ social, pero desde luego era muy poco conducente al aumento de la población española, y habrá que tenerlo en cuenta como un decisivo factor de la baja fecundidad que acusan los censos.

\section{Rentabilidad del Oficio Público}

Las listas agregadas de Tello señalan no menos de 37 personas no gratificadas que sirven o han servido cargos de guerra o de justicia, o las dos variedades, y nos dan su calificación económica con las siguientes matizaciones: "tiene caudal"; "tiene algun caudal", o "poco caudal"; "esta pobre". De estos 37, que representan un porcentaje equivalente al $20.78 \%$ del total de 178,19 figuran como pobres; de ellos, 3 con el extremo de "muy pobres" y de uno se dice "eșta gastado". Estos 19 sujetos representan el $51.35 \%$ de las personas que ejercen o han ejercido cargos retribuidos en las islas a cuenta de la Real Hacienda, y entre ellos vemos a personalidades

57. A.G.I., Filipinas 6: Dasmariñas a S.M.; Manila 9 de Julio de 1592 y Manila 20 de Junio de 1593. En repetidas ocasiones antes de estas dos cartas en que se relatan casos concretos denunció Dasmariñas este abuso del que llega a decir que si no se corrige será ruina de la tierra y el desencanto de los soldados y . conquistadores. Pueden verse las cartas en la traducción inglesa de $B \& R$, VIII, 281-282; IX, 58-68. 
socialmente prominentes, como por ejemplo, Don Francisco de Castañeda, llegado a las islas el año de 1592 y regidor del Ayuntamiento, de edad de 36 años que "esta muy pobre"; el capitán Juan Juárez Gallinato, con oficio de Sargento mayor del Campo de Manila, que "ha servido a su magd. en las ocasiones y jornadas de mas importancia que en su tiempo se han ofrecido, e exerciendo los dichos oficios con su paga... esta pobre", al igual que lo está Domingo de Orbea, Alférez de la propia compañia de Gallinato; pobres hay Alcaides y teniente alcaides de los fuertes, oficiales de la Real Hacienda, solicitadores del fisco, capitanes de galera y de las compañías del campo de Manila, como verá el lector que se quiera tomar la molestia de pasar la vista por las listas que publicamos en suplemento documental.

En resumen, continuando el recuento, 11 sujetos $(29.72 \%)$ aparecen con "algún caudal" y sólo 7 (18.91\%) figuran bajo la calificación simple "tiene caudal", que acaso, estirando un poco el significado, pudiéramos hacer equivalente a moderadamente rico. Entre estos siete se cuentan un Escribano de Registros, el Alférez general del Campo de Manila, un Regidor, un Licenciado y Abogado Protector de los naturales y algún otro que ha ejercido oficios de justicia.

Hay en Manila, y aparecen en la lista, un cirujano y un boticario que señalamos como posibilidad de orientación sobre la rentabilidad de esta profesión sanitaria de servicio público: los dos, curiosamente, "tienen caudal con que pasar".

Estos datos estadísticos, aunque no definitivos por la inherente limitación de las listas, nos ofrecen una idea sobre la seguridad económica de los vecinos de las islas que tenían que vivir de las percepciones de un oficio, militar o civil, sin otros aditamentos, y por ellos vemos que esa seguridad era del todo tenue y que la renuencia a establecerse en Filipinas para vivir en el ejercicio de tales oficios está sobradamente justificada en vista del casi nulo atractivo que representaban para mejorar de condición.

Quédanos por analizar la influencia que para la economía de los vecinos de las islas significaba la merced real de poder comerciar con nueva España.

\section{El Galeón de Acapulco y la economía de los avecindados en las Islas}

Junto con el envío de situados de Nueva España es una merced real hecha a la población española como un aliciente económico 
más para su radicación, conservación y permanencia en las islas. Esto al menos, en teoría. Se inició desde los primeros años de la conquista y corrió libre de regulaciones y restricciones hasta 1593 en que el permiso de embarque, concedido generalmente a todos los avecindados se fijó en $\mathbf{2 5 0 . 0 0 0}$ pesos de inversión en géneros para Nueva España, con un retorno del doble la inversión, o sea $\mathbf{5 0 0 . 0 0 0}$ pesos, de plata hacia Manila. Ampliaciones posteriores elevaron el permiso a 300.000 pesos de géneros en $1702 ; 500.000$ en 1734 y 750.000 pesos de carga en 1776, siempre con el doble de retorno en plata. Los galeones eran propiedad de la Corona y mantenidos a sus expensas, constituyendo esta partida y el subsidio o situado la gruesa mayor de los gastos de la Real Hacienda en Filipinas ${ }^{58}$.

Recordemos también, para los no iniciados, las líneas generales del funcionamiento de esta merced real que el P. Delgado califica de "socorro universal para todos los pobres de la república, que no se hallará igual ni semejante en las ciudades de Europa" 59, y 10 haremos en las palabras del Agustín Zúniga:

"Este comercio, prohibido a los extranjeros, se reparte a los españoles, para lo cual se arquea el barco, y se regula cada uno lo que le toca..., de suerte que en cuatro mil piezas de a vara y cuarta de largo cada una, dos tercias de ancho y una de alto corresponde en cada fardo 125 pesos de principal, que es lo que se debe embarcar en cada pieza que llamanos boleta. Estas boletas se reparten a los vecinos de Manila según el orden establecido; a los regidores y alcaldes ordinarios se les dan ocho boletas a cada uno por su empleo; por ser del Consulado, por ser vecino de Manila, por ser viuda de español y por otros motivos se goza de una o de media o de más boletas. Hasta el Arzobispo y los militares tienen su repartición en las boletas del barco de Acapulco. Los pobres que no tienen que cargar, los que no pueden comerciar o no quieren beneficiar sus boletas, danselas a los ricos para que hagan uso de ellas por cierta cantidad, que les dan a ellos, que suele ser 80 o 100 pesos por cada boleta entera en tiempo regular, y en tiempo de guerra suele subir a más de 300 pesos. Antiguamente gobernaba la carga del navio el Cabildo de la ciudad

58. Los datos que aquí damos, muy conocidos por los historiadores, proceden del Extracto historial de Abreu citado en nota 53.

59. Juan J. DELGADO, Historia General, Sacro-Profana, Politica y Natural de las Islas del Poniente Llamadas Filipinas (Manila: Imprenta de El Eco de Filipinas de D. Juan Atayde, 1892) p. 223. 
acompañado de cuatro comerciantes compromisarios; pero desde que se estableció el Consulado todo lo arregla este Tribunal" 60 .

El comercio exclusivo entre Filipinas y Acapulco ha sido competentemente estudiado en sus aspectos fundamentales, y a nosotros sólo nos interesa, de momento, resaltar lo que significó para el asentamiento de pobladores en Manila y las islas y para su seguridad económica como vecinos de ellas. Anticipamos que bajo estos dos aspectos resultó profundamente negativo.

Ya la operación del sistema de este "socorro universal" llevaba en sí el germen de todos los fallos que invariablemente le aquejaron por sus dos siglos y medio de historia. Al ser una ayuda general perdió su efectividad para estimular un selecto asentamiento de pobladores y beneficiar substancialmente su situación económica, pues al diluirse los 500.000 pesos del permiso en las boletas fraccionarias de la totalidad de la carga, a cada vecino le había de corresponder una fracción menor a medida que la población aumentase; de ahi el continuo clamor de los vecinos por la amplicación del permiso y del tonelaje de las naos de la carrera, las sobrecargas que hacían zozobrar los galeones, las continuas tentaciones a transgredir los límites de la ley que regulaba el tráfico... El callejón sin salida era que las ampliaciones solicitadas, de concederse, implicaban un dispendio mayor de fondos para la Real Hacienda y una automática protesta de los mercaderes de Cádiz y Sevilla. Fallaba así el comercio del galeón en uno de sus objetivos principales: el atraer a las islas y mantener en ellas con una economía aceptable un núcleo substancial de población.

Si hemos de creer apreciaciones generalizadas de las fuentes documentales de la época, que nunca hemos visto comprobadas en el rigor inapelable de los guarismos, el comercio con Nueva España promovió una abundante corriente emigratoria a las Filipinas, y sin embargo ningún censo de los que conocemos acusa en números esa beneficiosa emigración. Lo que ocurrió, y tenía que ocurrir inevitablemente, fue que el fraccionamiento del permiso de carga en boletas promovió una desenfrenada especulación sobre ellas con capitales de vecinos de México que sin moverse de sus casas lograban muiltiplicar por ciento sus inversiones en la compra de géneros de China a través de agentes destacados en las islas, a quienes paga-

60. Joaquín MARTINEZ DE ZUNIGA, Estadismo de las Islas Filipinas o mis Viajes por este pais. Ed. de Retana (Madrid 1893) 1, 267. 
ban de un ocho a un diez por ciento del principal invertido ${ }^{61}$. Precipitó asi esta especulación en dirección a las Filipinas una corriente migratoria no de capitalistas, sino de capitales que no quedaban en ellas para beneficio general, sino que terminaban en China, en Macao y en la Costa de Coromandel, de donde procedian las mercancías cargadas en las naos de la carrera de Acapulco. A su vez, la concurrencia de plata y la creciente demanda de géneros extranjeros a las islas que constituia esencialmente la vida de esta clase de comercio, desencadenó la inflación y la carrera desorbitada de los precios agravando cada vez más la general depresión económica, con un casi total abandono de otras fuentes locales de riqueza.

Todos estos extremos estan suficientemente sufragados por el testimonio documental coetáneo y son, en gran parte, resumen de los estudios ya concluidos sobre el comercio de Acapulco. Lourdes Trechuelo recoge en su obra el testimonio de Morga sobre lo perjudicial del tráfico del galeón ${ }^{22}$, pero ya mucho antes en carta de 30 de junio de 1586 , D. Pedro de Rojas se explaya en exponer sus graves consecuencias: 300.000 pesos de plata consume cada año, nos dice, y el año presente mas de 500.000 ; pero no sólo plata consume, sino que también parece haber consumido el vigor antiguo de la raza, haciendo de los primitivos soldados-ciudadanos españoles mercaderes afeminados que viviendo entre el vicio y la relativa comodidad de especulaciones y ganancias les ha hecho olvidarse de extender y continuar la pacificación y conversión de los naturales, y concluye abogando por la supresión del tráfico a favor de una más intensa explotación de las fuentes indigenas de riqueza ${ }^{63}$.

En uno de los periódicos intentos de poner fin a la intervención de los capitales mejicanos en el beneficio del tráfico del galeón, el Ayuntamiento de Manila solicitó en 1623 del Gobernador Niño de Tábora autorización para convocar uno de tantos cabildos abiertos sobre materias de comercio, en el que los vecinos habrían de elegir, con arreglo a la Real Cédula de 1593, seis delegados de la ciudad, que trasladándose a México habian de encargarse de recibir, vender, administrar y remitir de vuelta a las Islas lo procedido de las ha-

61. A.G.I., Filipinas 27: Actas de los Cabildos abiertos para el envío de delegados a Nueva España: Vide nota $N^{\circ}$ 65. Sobre la nube de mexicanos que llovía sobre Manila, Arzobispo Benavides al Rey, Manila 6 de Julio de 1603, en que informa cómo el Cabildo y Regimiento le han pedido excomunión contra ellos para detener la avalancha: $B \& R$, XII, 113.

62 MARIA LOURDES DIAZ-TRECHUELO SPINOLA, La Real Compañia de Filipinas (Sevilla 1965) 250.

63. Rojas a Felipe II: 30 de Junio de 1586; en $B \& R$, VI, 269. 
ciendas que los residentes cargaban en el galeón, poniendo así fin a la actividad de los agentes de los capitalistas mejicanos que controlaban este tráfico a ambos extremos de la carrera de la nao ${ }^{64}$. Con tal ocasión elaboró la Corporación municipal un "papel de razones" en el que se traza la historia de los ruines rendimientos del comercio para los residentes, en cuyo beneficio fue instituido, y se ofrecen los argumentos que aconsejan la gestión directa por medio de los compromisarios que los mismos vecinos eligiesen. Acotamos de este documento lo que consideramos más pertinente sobre la influencia del galeón en la economía y población de las Islas:

La cantidad de dinero que en cada un año pasa a estas yslas es notorio como lo es que sin comparacion es mas lo que pasa de vezinos de nueva españa $\mathrm{y}$ otras partes que 10 que viene propio de vezinos desta yslas lo qual es bastantisima causa para que se compren las mercadurias a los grandes precios que se compran en esta ciudad, y que yendo muchos a la nueva españa corriendo la venta dellas por manos de tantos se vendan tan baratas como se vendan, pues al cabo de dos años que vienen las cartas quentas y rrestos de las correspondencias, haciendose bien la quenta se hallara en muchos casos perder del costo principal, $\mathrm{y}$ en muy pocos ganancias, tan poco que siempre es forzoso yr consumiento el caudal principal para el sustento y gastos ordinarios, conque han ydo y van tan a menos los caudales que es bien conocida la cortedad de ellos...

...Y si con la ejecución de lo susodicho (el envio de delegados de los vecinos a Nueva España) se ponia bastante ympedimento a que no uviese compañia entre vecinos destas Yslas y en la nueva españa y ansi mesmo se ponia ympedimento a que no pasase tanto dinero para solo emplearse a diez y a ocho y a menos por ciento, cossa lastimosa y que tiene acabada la contratacion deste Reyno, y se conseguia el comprar en estas yslas las mercadurias baratas y venderse a grandes precios en la nueva españa con muy grandes ganancias, y se conseguiria con evidencia ynfalible que a nueva de tan grandes ganancias avian de passar a estas yslas muchas personas a avecindarse y vivir en esta ciudad, cosa tan necesaria que lastima a quien siente ver que no passen como antes de aora pasavan tantos hombres a este Reyno que se quedavan y cas-

64. El Censo de 1634 indica tras el nombre del Alférez Andrés de Zárate; "Este fue el año pasado a la Nueva España por factor de las haciendas de los vecinos destas islas $y$ en el mismo exercicio estan ocupados en la dcha. nueva españa los Capitanes Luis Vela, Juan López de Olăez y Pedro de Monreal". 
savan en el, pudiendo tener a maraviua que en el tiempo presente passe alguno por aver la necesidad y malicia descubierto el embiar como queda dicho de la nueva españa cantidad de dineros a muchas personas desta ciudad para que los empleen tomando por el trabajo a seis, o ocho, o diez por ciento, conque los que los embian estando en sus casas tan a poca costa conseguir el empleo, y el que lo hace por conseguir el interes no rrepara en el daño que en el hacerlo hace a la republica siendo muy grandes los que desto doproceden (sic) de que resulta no passar nayde a estas yslas porque desde su cassa consigue las ganancias como si verdaderamente viviesen en esta ciudad, y ansi se va despoblando sin aver quien avite las cassas ni hincha los vacios de los vezinos que mueren" ${ }^{65}$.

Resulta, pues, comprobado que por la mayor parte los beneficios del galeón se repartían entre los capitalistas de Nueva España, reduciendo a un gran número de vecinos de Manila al simple papel de intermediarios; a otra parte considerable de los vecinos, con una boleta de carga, o una fracción de ella, sin posibilidad de comprar más, el tráfico de las naos de Acapulco les aportaba sólo un reducido subsidio que casi nunca excedía de la simple pitanza. Sólo un reducido grupo de la población de Manila y las islas podía competir con manifiesta desventaja con los capitalistas mejicanos en el comercio directo del galeón.

Tenemos a este respecto datos numéricos y concretos: sólo once entre los encomenderos de Manila aparecen como ocupados en "inteligencias", o transacciones comerciales, en las listas de Tello de 1599. Y de una población de cerca de los 300 vecinos, después de los pregones que la ley y costumbre prescribian para la convocatoria de todos los interesados en las materias a discutir en la asamblea pública del "cabildo abierto", sólo 50 individuos asisten al celebrado en 23 de octubre de 1623; 30 son los únicos interesados en el de primero de febrero de 1629 , y 64 son los presentes y firmantes en el de 8 de marzo del mismo año ${ }^{66}$. Como atractivo económico, el permiso de comercio significaba muy poco para el asentamiento de pobladores y para su permanencia en Filipinas con un mínimo de digno buen pasar.

65. A.G.I., Filipinas 27, Documento 385. Autos de ejecución de la Real Cédula de once de Enero de 1593.

66. A.G.I., Filipinas 27, Documento 385. Autos de ejecución de la Real Cédula de once de Enero de 1593. 
Andilisis cualitativo de la población a final del siglo XVI.

Las listas conjuntas del Presidente Francisco Tello en 1599 y 1600 nos dan un agregado de 178 individuos, la absoluta mayoria de los cuales son indudablemente vecinos de Manila. Teniendo en cuenta que la población de la ciudad no excedía los 300, estas listas pueden proporcionarnos una aceptable base estadística de clasificación. La instituímos bajo los siguientes apartados: a) Escala económica, b) escala social, c) estado civil, d) edad, y media de edad de llegada a las islas, e) media de permanencia y servicios.

a) Escala económica.- Los 178 vecinos varones, equivalente a un $60 \%$ de la población presumible de 300, se distribuyen así: 41 $(23.03 \%)$ pueden calificarse de ricos; $72(40.44 \%)$ de economía suficiente o pasable; 65 (36.51\%) son pobres.

b) Escala social.- Las listas incluyen 82 (46.06\%) encomenderos; $60(33.70 \%)$ soldados pobladores y ciudadanos ordinarios; 17 con título de capitán $(9.55 \%)$ y $19(10.67 \%)$ con título de alférez. Los capitanes y alféreces se entiende que han de ser de la reserva, pues sólo dos o tres compañías estaban de ordinario de guarnición en el campo de Manila; recuérdese que en el sistema militar español de la época, el capitán, organizador, jefe y propietario de su respectiva compañía, conservaba el título de su graduación aun después de que su unidad militar se habia disuelto o reintegrado a la vida civil. Lo mismo se puede decir de los alféreces o abanderados de las compañias. En cuanto al ejercicio de las profesiones civiles y militares hemos hecho mención de ellas en nuestras observaciones sobre el valor de los oficios.

c) Estado civil.- De los 166 varones emancipados de las listas del Gobernador Tello exactamente 83, o la mitad, son casados, sin que se nos de calificación específica para la otra mitad, que abarcaría solteros y viudos; sólo para uno de los casados se especifica el número de hijos: siete, que evidentemente mereció registro como caso extraordinario. Doce son menores bajo tutela.

d) Edad de los residentes y media de edad a la llegadia a las Islas.- Las listas que manejamos dan la edad de 137 sujetos residentes y no ofrecen datos seguros sobre este particular para los 41 restantes. Los 137 se distribuyen por edad de la siguiente manera: de 20 a 29 años, 10; de 30 a 39, 43; de 40 a 49, 54; de 50 a 59, 20; de más de 60 años, 8 y de 70 años, sólo 2. En porcentajes referidos a los 137 sujetos cuya edad se expresa predomina el grupo de entre 30 y 49 años con un $70.80 \%$ y a ambos extremos de la escala de 
edad tenemos el $7.29 \%$ para los comprendidos entre 20 y 29 ; un $14.59 \%$ para los de 50 a 59 años; sólo un $5.83 \%$ rebasan los 60 y un minimo $1.45 \%$ los 70 .

Medias de edad. Hemos calculado separadamente la media de edad de la clase encomendera con un resultado de 43.64 años, mientras que la media de edad de los que no aparecen retribuidos con encomienda es de 38.52 años. La media general de edad de los residentes comprendidos en las listas, incluyendo los menores de 20 años (calculado sobre un total de 144 sujetos) es de 39,29 años.

Nos ha sido igualmente posible estimar la edad de los españoles a su llegada a las islas con los siguientes resultados y distribución: 32 llegaron de niños o muchachos en edades comprendidas entre los ocho y los dieciocho años y la media general de edad a la llegada, calculada sobre un sondeo de 133 sujetos, es de 25.72 años. Sesenta y cuatro llegaron en edades comprendidas entre los 20 y los 29 años; treinta y tres tenian entre 30 y 39 años al llegar y sólo cuatro entraron en las islas con 40 años. Los que arribaron en edad menor representan, pues, el $24.06 \%$; los llegados en los años veinte de su edad son el $48.12 \%$; sólo una proporción del $3.00 \%$ entraron con cuarenta años y un $24.81 \%$ con treinta o más años. Fuera de los 133 cuya edad de llegada se expresa hay 15 menores, hijos o nietos de españoles, que son presumiblemente criollos, o nacidos en las islas. La proporción de criollos varones (sólo se registra entre ellos una hembra) respecto de la población también masculina, en estas lista de Tello, sería entonces un $7.86 \%$.

e) Media general de permanencia y servicios. Calculamos esta variable sobre los datos verificables en las fuentes para 160 sujetos con un resultado de 17.15 años de media de permanencia en las islas y de servicios a la Corona en las mismas. Separadamente hemos considerado este aspecto con relación a los sujetos que en las listas figuran como no retribuidos. Sobre un sondeo de 96, la media de años servidos sin retribución es de 14.57 , lo cual nos ayuda a entender la larga espera y la casi infinita desesperanza del español que servía los designios reales en Filipinas. La media no refleja más que el punto general, pero los casos extremos son dramáticos: Se podía servir al Rey por treinta años y más, estar "cargado de mujer y hijos", sin ninguna gratificación, y vivir "muy pobre", como el Alférez Juan Núñez. $O$ como el Capitán Francisco Rodriguez, que acumulaba treinta y siete años de meritorios servicios, y haber recibido sólo una encomienda de seiscientos tributos, insuficiente del todo para mantener casa y familia, a pesar de haber llegado con el Adelan- 
tado...: O Esteban Pérez, el Viejo, llegado en 1568, de 64 de edad, que es casado y pobre.

La merced real como retribución era lenta en llegar y cuando llegaba, no bastaba para todos, lo que dramatiza aún más el difícil aspecto económico del español en las islas. Por otra parte, la munificencia real, lenta en llegar y casi siempre escasa en cubrir necesidades, podía revestir en ocasiones anécdóticas un matiz conmovedor, casi sublime en su escueta sencillez: Juan verdugo, un hombre de nuestras listas, se veía recordado por el corazón del Rey que desde su celda del Escorial escribía a Dasmariñas en las instrucciones de gobierno: “...y particularmente terneys quenta y cuidado con la gratificacion de los que aqui yran referidos. ...Juan Verdugo que perdio el brazo derecho en mi servicio" ${ }^{67}$.

\section{Observaciones al censo de 1634}

1. Llamamos especialmente la atención sobre el bajo índice de reproducción, expresado en el $59.35 \%$ de matrimonios sin hijos que da una bajísima media de sólo 0.81 hijos para cada uno de los 155 matrimonios registrados, situación todavía agravada por el hecho de que entre los 24 matrimonios que figuran con un solo hijo, hay 15 cuyo único hijo tiene una edad, superior a seis años, lo que muy probablemente constituye a los cónyuges en el estado que los modernos ginecólogos describen como "fecundidad terminal" ". La media general de hijos por matrimonio, incluidos los vástagos directos de viudos y viudas, apenas si pasa de 1.28. La baja fecundidad del español en Filipinas, dato ya suficientemente conocido y expresado con frecuencia en términos generales, adquiere una contundencia dramática ante la desnudez de los güarismos ${ }^{69}$.

67. Punto N..$^{\circ} 13$ de las Instrucciones a Dasmariñas en COLIN-PASTELLS, Labor evangélica, III, 744. Advirtamos, con pena, que a pesar de esta conmovedora recomendación real, Juan Verdugo, víctima triste del olvido o la preterición de uno de los mejores Gobernadores de las Islas como fue Dasmariñas, figura en nuestras listas todavía como no gratificado: "El Alferez Juan Berdugo a viente años que sirve a su magd. en dchas. yslas en la pasificación y conservacion de ellas $\mathrm{y}$ ultimamente aviendo la jornada de cagayan a su pasificacion el año pasado de ochenta y quatro perdio el brazo derecho en servicio de su magd. no tiene gratificación de sus servicios esta pobre y merese ser gratificado".

68. Esta variable hemos podido cacularla por el hecho de que el censo da sólo la edad del hijo mayor en cada matrimonio fecundo. Por lo mismo, no es posible determinar la variable de espaciamiento de hijos para las familias del censo con más de dos hijos.

69. DELGADO, Historia general, p. 855; DIAZ-TRECHUELO, La Real :Compañia, 251. 
Las causas parecen ser no sólo de carácter fisiológico, sino tambión social y económico, pues aunque no se expresa en este censo, podemos asumir que la frecuente ocurrencia de casamientos en edades desproporcionadas entre los cónyuges se extendió hasta más adelante de estas fechas. Está desde luego, suficientemente clarc que la baja fecundidad general no se debia a la falta de mujeres, aunque haya influido en debida proporción. De hecho las mujeres españolas fueron llegando a las islas a partir de 1570, en que empezó la repatriación de las esposas de los primeros hombres de Legazpi, y acompañaron a los refuerzos que después fueron llegando ${ }^{70}$.

Tenemos documentada, a este respecto, la arribada a Panay del matrimonio que produjo el primer criollo, o español nacido en Filipinas: Francisco de Salazar, que en su día llegó a ser Alcalde de Manila, hijo de Juan de Salazar y María Bermudez, de la cual se nos dice:

"pocos dias después de aver llegado de la nueva españa a la dcha. ysla de Panay, la dcha. Maria Vermudez que vino preñada pario a el dcho. Capitan Francisco de Salazar... e sabe (esta testigo) fue el primer español que nacio en estas yslas porque hasta entonces no habia nacido otro $y$ esto sabe de la pregunta y responde a ella" "11.

Desde muy pronto, además, los españoles tomaron mujeres naturales por esposas, y esto de manera más o menos regular, según las fuentes dejan entender. En el limitado censo de las listas del Gobernador Tello, entre los 19 encomenderos de Cebú encontramos ya la manifestación de esta tendencia, al registrarse los casos de Mateo Sánchez, cuya viuda india casó con Alvaro Tineo que recibió de ella la encomienda heredada de su primer marido, y el de Juan Méndez de Sotomayor, casado igualmente con una cebuana, cuyo

70. En el asiento de la encomienda de Don Pedro Briceño de Oseguera (Suplemento documental N.o 1) se menciona a su padre, el Capitán Pedro de Oseguera "que fue el primero que murio en servicio de la fe de dios nuestro señor y de su magestad", y se hace también mención de "doña beatriz Ossorio su madre ques de las primeras pobladoras que an benido a esta tierra desde el año setenta".

71. A.G.I., Patronato 53, Ramo 19. El testigo es Gaspar Pérez, un hombre de nuestras listas, "Sargento Mayor que ha sido deste real campo, uno de los mas antiguos vecinos desta ciudad", que depone en su misma casa por hallarse "enfermo y con calentura a lo que parecio, de que doy fe", dice el escribano. Se abrió la información a pedimento de Francisco de Salazar ante la Audiencia, en persona de Dn. Manuel de Madrid y Luna, sobre méritos y servicios propios y de su padre, 6 "pretende del Rey nro. señor le haga merced... de tres mil tributos de encomienda y que asimesmo le haga merced de poner en cabeza de Dña. Maria de Salazar su hija encomendera de Oton y Butuan, en que sucedio como nieta del Capitan Miguel de Loarca, la dcha, encomienda". 
hijo mestizo aparece en posesión por herencia de la encomienda de su padre ${ }^{72}$.

El primer censo conocido del Ayuntamiento de Manila apunta igualmente este detalle:

"Ay en la ciudad cincuenta españoles casados con españolas y otros con yndias naturales e quince biudos españoles y ocho o diez docellas y otras que son muy niñas" ${ }^{73}$.

La relación, por otra parte, de 240 hembras por 386 varones en el total del censo de 1634 no la encontramos exageradamente desproporcionada, como tampoco lo es la cifra de 584 mujeres mayores en el recuento del Arzobispo Serrano, respecto de la población total de Manila ". Parece, pues, convincente que la "falta de mugeres", que pudo ser muy cierta en los comienzos de la colonización cuando Legazpi la apuntaba, no pudo influir de manera tan decisiva en el retraso poblador de las islas ${ }^{75}$.

Así las cosas, no cabe duda de que los factores decisivos de ese retraso se reducen principalísimamente a tres, y por este orden de influencia: el escasísimo incentivo económico que agostó en flor la corriente pobladora; el extraordinariamente bajo nivel de reproducción de las familias que a pesar de todo se asentaron en la tierra; y el indudablemente alto índice de mortalidad.

\section{El indice de mortalidad}

El español radicado en Filipinas no se adaptó - o lo logró muy tarde- ni física, ni climatológicamente a la tierra. Rara vez llegaba a los sesenta años de su edad: en nuestros cómputos sobre las listas de Tello sólo en una proporción de un $5.83 \%$ conseguía esa extensión de vida. Legazpi, ya lo hemos notado, apuntaba en su carta al Virrey de Nueva España la desaparición en año y medio de diez o doce de los 50 españoles que dejó poblados en Cebú, más otros tantos inútiles por "tullidos y enfermos" " Sancho Díaz de Ceballos nos dice de la tierra que "en extremo es enferma porque es un hor-

72. Véase Suplemento documental 1.

73. A.G.I., Filipinas 32: "Relación de los naturales..."; Cf. COLIN-PASTELLS, Labor evangélica," Ir, 674-681.

74. A.G.I., Filipinas 74: Arzobispo Serrano a S. M., Manila 21 de Junio de 1622 : PASTELLS, Historia general, VII, LXXV-LXXVI.

75. A.G.I., Patronato 24, Ramo 23.

76. A.G.I., Patronato 24, Ramo 23. 
no de vidrio, y asi cada año tenemos menos casi cien hombres" $" 77$. Al pedir las autoridades de las islas al Rey el envio de los 160 misioneros adicionales que se echan de menos para proveer de doctrina a todos los naturales reducidos, se advierte que los religiosos deben ser reclutados $\mathrm{y}$ embarcados inmediatamente, e incluso un número mayor, pues para cuando lleguen, una cuarta parte de los 140 existentes habrán ya muerto ${ }^{78}$.

Las muertes y miseria afectaban por igual a la población militar y civil; las condiciones sanitarias eran deplorables; aunque hay que notar la presencia de algún cirujano e incluso algún médico antes de la organización y dotación del Hospital de españoles ${ }^{79}$, las cartas y peticiones al Rey frecuentemente insisten en la necesidad de médicos y medicinas, pues los enfermos tenían que curarse "a tiento" ${ }^{80}$. Da pena leer el Capítulo 6, del Memorial de Todos los estados, relativo a las necesidades de los soldados, aun descontando el pico de exageración que posiblemente encierra:

"Lo 2." que andan pobres, abatidos, deshonrados, enfermos y necesitados... con los quales trabajos y tristezas y ambres

77. A.G.I., Filipinas 34 .

78. RETANA, Archivo del Bibliófilo filipino, IV, 41-111.

79. Uno de los primeros médicos que ejercieron su profesión en Filipinas fue Grabriel Hernández Cavello, según consta de un proceso del Ayuntamiento de Manila contra él, pretendiendo despojarle de la encomienda que se le había concedido. Este proceso se inicia por certificado de Diego Alemán, escribano de Cabildo, a 25 de Febrero de 1572 (A.G.I., Filipinas 27). En nuestras listas figuran Alvaro Pérez y Hernando Ramírez, cirujano y boticario, respectivamente, llegados ambos en 1581. Antonio Espejo, otro cirujano, arribó a las islas en 1584. El Censo de 1634 incluye también dos profesionales de la medicina entre los vecinos de Manila.

80. El cirujano Pérez y el boticario Ramirez fueron enviados muy probablemente en respuesta a las cartas del Gobernador $y$ del Ayuntamiento en $\mathbf{1 5 8 0}$ en que pedían un boticario con medicinas y un médico: "Entiendo embiase con esta recaudo desta ciudad para que se asalarie un médico en esa con mil pesos de salario y mas sus provechos de que hay gran necesidad en esta tierra". (Gonzalo Ronquillo, Manila, 18 de Junio de 1580: AGI., Filipinas 6). De Vera, en carta de 13 de Julio de 1589 insistía en la necesidad de médicos, pues los cirujanos residentes parece resultaron insatisfactorios: "...No ay medico ni medicinas... Aunque V. magd. tiene mandado proveher este campo y ospitales de medicinas y cosas necesarias como no ay medico no se curan los soldados sino a tiento y por parecer de cirujanos sin letras y por esta causa se mueren mucha gente. Suplico a V. magd. pues tanto ynporta a su servicio mande al Virrey de nueva españa ynvie un buen medico con salario competente a costa de Vra. Rl. Hacienda que ni la ciudad tiene propios para pagarlo ni los soldados lo pueden hacer pues aun para sustentarse no tiene el más rico". ( $A G I$., Filipinas 18). Todavía en 15 de Julio de 1658 escribía el Cabildo: "No es menor la falta que ay de medicos; uno ay y no más y cirujanos ninguno. También pide esta necesidad el remedio de la nueva españa mandando $V$. magd: a su Virrey elija algunos de esta profesion para que pasen a estas islas examinados en su arte $y$ bien opinados": A.G.I. Filipinas 27). 
y poco regalo ni provission en las infermedades mueren muchos y con mucho desconsuelo...

Y no sólo los soldados estaban en tan miserables condiciones, pues el Memorial continúa diciendo:

"El quinto que los hombres honrados y principales y cavalleros que por particulares occasiones y fines an venido es cossa lastimera verlo pobres mal vestidos sin casa ni servicio ni comida y necesitados a pasar. Hambres y verguencas para remediarlas comiento un dia en una cassa y cenando en otra" 81 .

Nos hariamos interminables, si decidiésemos recorger la mayoría de los testimonios de primera mano referentes a este asunto. Las privaciones de todo género, las adversas condiciones climáticas y los trabajos de la conquista y reducción de la tierra iban continuamente más que diezmando la colonia de españoles. En 1589 escribia a S.M. el Ayuntamiento de Manila:

"De tres años a esta parte que el marques de Villamanrique es birrey de la nueva españa no se a enbiado a estas partes el socorro de gente armas y municiones que de hordinario se solia enbiar y como en esta tierra se mueren tantos soldados con la necesidad y travajo que pasan an venido a quedar tan pocos que todas las compañias de ynfanteria que ay en este campo no llegan a trezientos y pocos mas y si el Govor. y capitan general no les ayudara a los mas necesitados con algun socorro de arros que movido de compasion les hace los obiera la hambre acavado. Porque con verdad podemos certificar que se an visto algunos morir della miserablemente" ${ }^{82}$.

$\therefore$ Comunicando al Rey la pacificación de Cagayan y el nuevo descubrimiento de Tuy, escribe Dasmariñas que su propio hijo Luis y "quasi todos los soldados" de la expedición enfermaron seriamente, y añade:

"Con estas jornadas y pacificaciones y ser la tierra de suyo no bien sana y particularmente este año muy enfermo en comun a españoles y yndios se me han muerto muchos sol-

81. A.G.I., Patronato 24, Ramo 66. 1589.

82. A.G.I., Filipinas 18: Cabildo Secular a S. M., Manila, 13 de Julio de 
dados que de todos quatrocientos no me han quedado sino doscientos y aun no, y aunque esta plaza de la manera que aora esta con mucha menos gente se podra defender al fin sin ella no ay sitio seguro y vienele de tan lexos como es españa y quando llega socorro de alguna esta ya muerta la mitad de la que aca ay y si un año (como acontece) falta nave de Castilla es lastima ver qual esta en todo esta tierra" 83 .

La tierra, pues, y el esfuerzo por reducirla y conservarla, iba tragando hombres a un ritmo en ocasiones superior al en que se producían los refuerzos que se mandaban desde los lejanos centros de provisionamiento y al de la natural reproducción interna ${ }^{84}$. $Y$ parece que la situación no cambió significativamente con el paso de los años, y ni aun de los siglos, pues la segunda mitad del siglo XVII marca el punto mas bajo, quizás, de la población española en las islas y son suficientemente citadas y conocidas las palabras del P. Delgado ${ }^{85}$ de que la población española que el conoció en 1728 había desaparecido totalmente en 1751.

Hemos intentado, y no creemos haber podido lograrlo, el reducir a expresión numérica la proporción del índice de mortalidad. Nuestros datos son por el momento insuficientes, dispares y dispersos, y creemos que continuarán siéndolo, si nuestra búsqueda de alguno de los libros de Defunciones de la Parroquia de españoles del Sagrario no rinde el deseado fruto, siquiera sea sólo en copias o fragmentos que puedan ser referidos a alguno de los censos de población española que poseemos ${ }^{\star}$.

Más con intención de señalar un enfoque metódico para el estudio de este problema que con fe en nuestros propios resultados provisionales, of recemos el siguiente análisis comparativo. Nos valemos de dos listas parciales de vecinos de Manila en fechas referibles al censo de 1634. El primer sondeo comprende 50 presentes y firmantes en el "cabildo abierto" de 23 de octubre de 1623, a unos diez años fecha de la compilación del referido censo, y el segundo incluye 64 asistentes y firmantes a otra asamblea de la misma naturaleza en 8 de marzo de 1629, o sea, cinco años antes de completar-

83. A.G.I., Filipinas 18: Dasmariñas a S.M., Manila, 31 de Mayo de 1592, en COLIN-PASTELLS, Labor evangélica, I, 586-587.

84. A.G.I., Filipinas 6: Tello a S. M., Manila, 12 de Julio de 1599 ; en $B \& R$, $\mathrm{X}, 207-208$.

85. DELGADO, Historia general, 855.

86. Conservados en el Palacio Arzobispal y usados por algún raro investigador, estos libros desaparecieron cuando el Archivo Arzobispal recibió el impacto direcho de una bomba en la pasada guerra mundial. 
se dicho censo ${ }^{87}$. Pues bien, sólo 14 de los 50 firmantes en $1623 \mathrm{fl}-$ guran en la lista de los vecinos censados por el Ayuntamiento en 1634, acusando una desaparición en diez años, poco más o menos, de 36 individuos, que equivale a una mortalidad natural o civil del $72 \%$ del sondeo. De los 64 presentes en 1629, sólo 36 aparecen incluidos en el censo indicado, mientras que 28 , igual al $43.75 \%$ ya no rezan como vecinos a cinco años fecha. La dificultad fundamental en aceptar estos porcentajes como normativos del índice de mortalidad radica en que ellos no hacen distinción entre la baja en el censo (mortalidad civil) y la defunción (mortalidad natural), aunque los consideramos válidos para los efectos de calcular en general la desaparición de los avecindados en Manila, puesto que sea por muerte civil o natural, la ciudad se quedaba sin el indicado número de ciudadanos activos ${ }^{88}$.

Esperamos volver a tratar sobre el tema $y$ de momento ofrecemos estos resultados provisionales, de los que se deduce que la mortalidad natural era extraordinariamente alta, aunque no podamos expresarla en porcentajes satisfactorios.

\section{El perfil humano y sociológico de la población}

Como corolario casi inevitable de todo lo anteriormente expresado tenía que seguirse una corriente pobladora generalmente pobre en valores humanos. No abundaron las personalidades completas y atrayentes entre el elemento militar y civil, y la presencia de hombres de la talla de Juan de Salcedo, Esteban Rodríguez de Figueroa o Sancho Díaz de Ceballos constituye más bien la excepción que la regla. No abundó el tipo del soldado renacentistas; hay entre las mesnadas que se reclutaban con harta dificultad en Nueva España y terminaban por quedarse como soldados-ciudadanos su generosa dosis de analfabetismo hasta un grado y en una proporción que no nos hemos preocupado de determinar por no considerarlo específicamente relevante para nuestro propósito y porque después de todo es normal y natural para la época. No fluyó desgraciadamente hacia las islas lo mejor de la sangre española, ni mucho menos.

87. A.G.I., Filipinas 27: Actas de Cabildos abiertos.

88. Nótese que en ambos sondeos nos resulta un índice de mortalidad indiferenciada superior al del P. Delgado, lo cual nos hace dudar todavía más de estos iniciales tanteos. No hay duda, desde luego, de que la mortalidad era altísima, y que no podía ser compensada por el índice de reproducción interna, y en ocasiones y épocas concretas, ni por ella y la inmigración externa conjuntamente. 
El Dr. Santiago de Vera en 1587 declara simplemente que "no pasan sino el desecho y como la tierra no es sana y 10 pasan tan mal, la mayor parte se mueren y otros se huyen sin lo poder remediar":89:

El P. Alonso Sanchez, al presentar al Rey el Memorial de todos los Estados, lo acompañó con unas observaciones propias "para la inteligencia de él (el Memorial)", donde leemos:

"La primera raíz y causa de todos los males y travajos de aquellas yslas es que ansi como son la tierra mas apartada de españa ansi la gente que va alla es de ordinario la mas pobre y de vaxa suerte y que llega mas necesitada y adeudada y con mayor hambre de repararse y enriquecer y ansi tambien como es la tierra mas apartada de la iglesia y xtiandad antigua ansi es la gente mas desbaratada y ancha de consciencia y como es tambien la mas apartada de v. md. y de su rreal presencia ansi es la gente mas libre y esenta y la que menos respectos tiene que la refrenen o moderen y de estas tres cosas podra v. ma. colegir mejor que de otras Razones la dispusicion que tiene la tierra" 90.

Añade en el punto cuarto que como consecuencia de la inseguridad social, pues la tierra "ni esta ganada ni allanada ni pacificada", y del ningún estímulo económico, pues "ninguna cosa se da a los soldados, ni paga, ni provision de vestido ni comida...".

"no ba la gente que es menester, o si de la nueva españa va alguna como va de su voluntad y a tierra donde sabe que no ay mas premio ni socorro que lo dicho, ni van hombres de hedad ni honrra ni valor ni esfuerzo, sino muchachos huydos de sus padres, o mesticos, o desterrados o afrentados por delitos y llegando alla como no ay orden ni disciplina militar, bien se vee que gente sera y que efectos hara pues el poco recaudo y arrimo que alla ay no solo a los que son de esta calidad pero a otros que son gente honrrada y noble tiene muy aflixidos y descontentos y siempre con gana de bolverse y huirse si pudiesen..." 91 .

Desde muy pronto aparece en la correspondencia informativa de las islas la nota negativa de verdaderos valores humanos en: su

89. A.G.I., Filipinas 34 : Licdo. Santiago de Vera a S.M., Manila 26 de Junio de 1587.

90. A.G.I., Patronato 24, Ramo 66.

91. A.G.I., Patronato 24, Ramo 66. 
población militar y civil y va causando impresión en el investigador que la examina de conjunto. Conocidas son las apreciaciones condenatorias de los primeros Agustinos sobre la desenfrenada conducta de una gran parte de los hombres de Legazpi en la base de Panay y las recriminaciones de los misioneros a la debilidad cuasi senil del propio Adelantado en refrenar los desmanes de su gente ${ }^{92}$. De Panay el campo militar y el núcleo poblador se estableció en Manila y los observadores coetáneos, al fijar de cuando en cuando su atención sobre el complejo social, nos revelan con frecuencia la pululación de abundantes elementos negativos que auguran, ya desde la época gestadora, la plasmación futura de una sociedad en turbulencia y en contradicción consigo misma.

Sancho Díaz de Ceballos, desde la altura de su cultivada superioridad, se pronuncia bastante negativamente contra el grupo de españoles en Manila, trayendo en apoyo de su juicio las observaciones perspicaces de los huéspedes chinos:

“...Y lo que peor es que en todo el remedio de estas cosas hay tan gran tibieza y descuydo que con solo menospreciar esto con palabras vanas se contentan y desde aca lexos cada vil hombre mata toda la China, y plega a Dios que valga uno solo contra dos, que habra hecho mas valentia que Hercules. Acuerdome que tratando un dia con Chalutle, Capitan General de los Chinos, hombre sagaz y muy ingenioso, familiarmente como muchas veces solia, entre otras cosas le pregunte que le parecia de nuestra gente, respondiome que eramos gente que facilmente se determinaba a morir, mas que eramos pocos y muy confiados y sin alguna industria: que creo yo que si como dixo pocos dixera locos que acertara del todo: porque no hay hombre que sepa mas que tirar un arcabuz, y eso se sabe en un momento, y todos creen que por esto merecen ser capitanes generales de un grueso exercito: no querria que tan vana jactancia viniese (como suele) a caer vilmente" ${ }^{93}$.

92. En la controversia suscitada sobre esta clase de correspondencia, nuestro parecer se inclina con los que creen que los hechos relatados no son exageraciones de celo misionero, sino que describen situaciones reales. Después de todo, la conquista, bautizada para Filipinas con el paliativo de "pacificación" desde las remotas cámaras reales, si bien instituyó un mejorado procedimiento metódico en las entradas y subordinó la acción del sometimiento a principios muy de acuerdo con el pensamiento teológico-jurídico de la época, no salvó las ocasiones concretas, una vez rotas las hostilidades, de las violencias de todo ejército de ocupación. Los soldados de Legazpi no eran ángeles y más bien, ellos y los que después vinieron, tenían abundantes vetas de todo lo contrario, y en las situaciones extremas en que se encontraban, era lógico reaccionasen como lo que eran.

93. A.G.I., Filipinas 34. 
Jactancia y autosuficiencia, desprecio por lo que la tierra ofrece, tibieza, carencia de industria $\mathrm{y}$ desinclinación al trabajo, esto compensado con la gran virtud tradicional española, el arrojo ante la muerte ${ }^{94}$.

De "albañal y desaguadero" ${ }^{95}$ para los más espinosos problemas de los Virreyes de Nueva España calificó en cierta ocasión Dasmariñas el territorio de su jurisdicción de Filipinas, y en esta situación no habrá de sorprendernos que la sociedad así contaminada le mereciera un muy pobre concepto ${ }^{96}$.

Ni puede sorprendernos tampoco que Morga después de él detectase en esa misma sociedad la presencia y la práctica de un buen número de los vicios sociales que hoy mismo encontramos censurables en estas tierras: el uso del oficio público como medio de enriquecimiento a costa del fraude del erario; el poco respeto a la propiedad privada; absentismo en el servicio público; la rivalidad por relumbrar, el lujo y la extravagancia; el vicio del juego de azar entre los hombres por grandes cantidades, y el de cartas entre las mujeres que se pasan en estas diversiones la mayor parte del tiempo de sus reuniones y visitas; el compadrismo; la holgazanería, la pública indisciplina y el concubinato ${ }^{97}$.

Es noble reconocer que esta sociedad española, influenciada por un río de desechos de Nueva España que desaguó aquí casi inevitablemente por las difíciles circunstancias migratorias, hubo de dejar, y de hecho dejó, un funesto sedimento de taras disolventes en lo social y ciudadano. Cuántas de ellas y en qué grado de influencia han sido heredadas por la presente sociedad filipina es problema que debe resolver la sociología y la historia. Nosotros constatamos aquí que, a pesar de la buena voluntad de la Corona y a pesar de los controles institucionales, el bombardeo de elementos indesea-

94. Este arrojo personal, probado en acciones guerreras era el ingrediente más frecuente de las informaciones de servicios por las que se concedian con las indispensables recomendaciones los puestos públicos militares y civiles; situación que gravaba la administración de las islas con una buena cantidad de ex-soldados incompetentes. Véase, a este respecto, el documento anónimo sobre reformas necesarias en las Islas, recogido por $B \& R, \mathrm{X}, 111-112$, tomado de $A . G . I$., Filipinas; Cartas y expedientes de personas seculares... años de 1565 a 1594 : Leg. 34

95. Dasmariñas a D. Antonio Juan de Ibarra, Manila, 10 de Junio de 1592 : COLIN-PASTELLS, Labor evangélica, I, 577.

96. Cf. COLIN-PASTELLS, Labor evangélica, I 579: Dasmariñas a S.M., Manila, 20 de Junio de 1592.

97. Antonio de Morga, Informe sobre la situación de Filipinas, Manila, 8 de Junio de 1598: $B \& R, \mathrm{X}, 75-102$, passim. 
bles continuó por décadas y aun por siglos, en palabras de un observador, "para descrédito del nombre y la nación española" ${ }^{8}$.

En 1650 Diego Fajardo protesta -una de tantas veces más de las muchas protestas oficiales - de un exiguo y tarado refuerzo de soldadesca vertida desde México sobre las costas filipinas:

“...Ademas de ser muy pocos los que han venido de Nueva españa y estos mulatos y indios y gente de mal hacer son muchachos los mas que necesitan de estarse en una escuela (como a ella los e ymbiado) que ocuparse en cosa alguna de servicio; y esta misma forma abra Señor en adelante en este embio si la grandeza de Vuestra Magestad no da lo que a esta conviene para que se remedie porque los mas que se conducen en aquel Reyno que pueden ser de servicio para ymbiarlos sueltan de la carcel de corte del algunos ministros por trescientos pesos o por mas y menos cantidad que dan aunque esten sentenciados para venir a estas yslas a servir por grauisimos delitos que an cometido y lo mismo hacen los castellanos de acapulco y los oficiales reales de alli al embarcarlos por el interes que se les sigue $y$ asi bienen solamente aquellos que no tienen con que redimir su venida..." 99 .

La práctica de la remisión de reos subsistía en el siglo XVIII, según consta de la siguiente petición del Ayuntamiento de Manila:

"Muy Ilustre Señor: El General Dn. Atanasio Fernandez de Guevara Regidor y Procurador General de esta Nobilisima Ciudad, parezco ante V. Sa. en debida forma y digo: Que en cabildo celebrado oy de la fecha acordo mi parte suplicar a V. Sa. se sirva mandar que por lo que constare de los libros, papeles y listas de la Contaduria de veinte años a esta parte, se de a mi parte razon de todos los sugetos que de el Reyno de Nueva España e Yslas Marianas, y han(s) sido remitidos y desterrados por las reales Audiencias $\mathrm{y}$ otros cualesquier Justicias, para que teniendose presente esta razon y por este medio obiar(s) el inconveniente de recibir al vecindario de esta Nobilisima Ciudad y a sus Oficios publicos a los sugetos que estuvieren notados con dicha remisión, y que pudiera recibir mi parte en perjuicio

98. Documento anónimo sobre reformas citado en nota 94, p. 124.

99. Fajado a S. M., Manila, 4 de Agosto de 1650: COLIN-PASTELLS, Labor evangélica III, 540 . 
de la causa publica ignorando la caltdad cle impedimento por que debieran ser excluidos para lo que: A. V. Sa. pido y suplico se sirva habiendome presentado, mandar segun que expreso y reproduzgo(s) pór ser justicia que espero de la grandeza de V. Sa. y en lo necesario etc. Atanasio Fernandez de Guevara. Manila y Noviembre 26 de 1725" 100.

La lista de reos contra los que el Ayuntamiento quería prevenirse fue debidamente presentada, e incluye para los años 1713 a 1725,192 sujetos con sus nombres y delitos; por ella se ve que cada año tenía Manila una dosis apreciable de delincuentes españoles actuando al margen de su ya contaminada sociedad: 18 en $1713 ; 4$ en $1715 ; 53$ en $1722 ; 79$ en $1723 ; 24$ en 1724 , y 14 en $1725^{101}$.

Creemos que el elemento estabilizador en esta sociedad fue, muy probablemente, el religioso, que con su influencia espiritual suavizó las hirsutas aristas del turbulento complejo ciudadano, en cuanto cabe, pero los datos que hemos ofrecido sobre la injerencia de determinados factores deletéreos a lo largo de su proceso formativo han de tenerse en cuenta para interpretar correctamente desde una perspectiva histórico-sociológica más de un episodio confuso de nuestro común pasado, y para leer a mejor luz los signos, a veces contradictorios, del presente. Al fin y al cabo, esta es la misión especifica de la Historia, a la que esperamos no haber defraudado con este puñado de páginas.

Escribiendo en 1850 Rafael Díaz Arenas afirmaba que no hay nada más difícil que acertar con la población de Manila. Conscientes nosotros de las mismas dificultades, no creemos haber podido en conjunto resolverlas. No obstante, al reunir en exposición sistemática los datos dispersos de las fuentes primarias y al aportar alguno que otro nuevo, con el método y enfoque que aquí hemos seguido, confiamos poder ayudar al curioso por estas materias a formarse una idea más aproximada de la base numérica y de los ingredientes valorativos que entraron en la plasmación gradual del tipo de sociedad española que vino a establecerse en Manila. Como todas las sociedades rectoras en la Historia son por su misma naturaleza ejemplares y normativas, esta sociedad, con sus virtudes y defectos, hubo de transmitir en el proceso de asimilación cultural una apreciable dosis de los mismos a las gentes que la rodeaban; y las consecuencias de esa asimilación tienen que contarse aún hoy como

100. A.G.I., Filipinas 188.

101. A.G.I., Filipinas 188. 
parte constitutiva del ser social filipino. En eso radica su importancia.

Por lo que se refiere a nuestro inmediato objetivo, el estudio de la Institución municipal la investigación precedente ha de constituir la base de las futuras evaluaciones y apreciaciones de su constitución, funcionamiento y eficiencia. 
DISTRIBUCION ANALITICA

Intramuros

Extramuros

A) Distribución residencia

de vecinos

265

13

Casados

Viudos

B) Estado Civil

$155=54.77 \%$

$33=11.66 \%$

Ayunta- Generales

Sargentos

miento

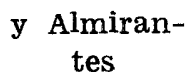

Mayores Capitanes

C 1) Situación

Social, pro-

fesional y económica

C 2) Distribución de encomiendas por grupo

D) Fecundidad Matrimonial

$\begin{array}{cccc}9 & 11 & 4 & 27 \\ (15.00 \%) & (18.33 \%) & (6.66 \%) & (45.00 \%)\end{array}$

$$
\begin{aligned}
& \text { Casados: } \sin \text { hijos Con un hijo Con dos } \\
& 92=59.35 \% \quad 24=15.48 \% \quad 25=16.77 \% \\
& \text { Viudos: } 20=60.60 \% \\
& \text { y } \\
& \text { Viudas } 27=60.00 \% \\
& 155 \text { parejas de casados } \\
& 18=23.07 \% \quad 7=8.97 \% \\
& 45 \text { viudos } \\
& =310 \text { personas } \\
& 33 \text { viudos } \\
& =45 \\
& =33 \\
& 50 \text { solteros } \\
& =50 \\
& 188 \text { dependientes } \mathrm{y} \text { menore } \\
& =188 \\
& \text { (incluidos } 9 \text { nietos de } \\
& 6 \text { vecinos) } \\
& 626 \text { personas } \\
& \text { De ellos ..... } 386 \text { varones } \\
& \text { у..... } 240 \text { hembras }
\end{aligned}
$$


DEL CENSO DE 1634

España

1

Viudas

$45=15.90 \%$

Alféreces Real

Ayundantes $\mathbf{y} \quad$ Audiencia

Sargentos

32

$(13.44 \%)$

5

$(8.33 \%)$

Con tres

$7=3.87 \%$

$4=5.12 \%$
Nueva España

4

Solteros

$50=17.66 \%$

Escriba-

nos

12

$5.04 \%$ )

$(3.36 \%$

1

$(1.66 \%)$

Con cuatro

$4=2.58 \%$

$2=2.56 \%$

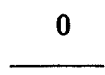

Con cinco

$2=1.29 \%$

0
Total

283

Menores $\mathrm{y}$ en tutela $188=66.43 \%$

Ciudadanos

Médicos Ordinarios

2

$(0.84 \%) \quad 24.36 \%)$

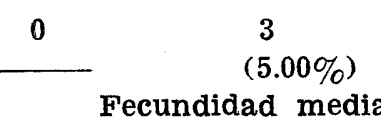

Con seis por matrimonio

$1=0.164 \% \quad 0.81$

$0-\quad 0.66 \ldots$ 


\title{
SUPLEMENTO DOCUMENTAL
}

\author{
N..$^{\circ} \quad$ I
}

Memoria de las personas benemeritas que ay en las yslas Philipinas, y los que tienen gratification, o no, de sus seruicios, y quienes estan gratificados y la rrenta y hacienda que cada uno tiene y los sujetos y partes, començando por los primeros encomenderos que binieron con el adelantado miguel Lopez de Legazpi y conquistaron y pacificaron estas yslas entrando por cebu ques la provincia de pintados donde primero poblaron.

\section{Encomenderos Pablados en Cebu}

Don Pedro Brisseño de Oseguera, soltero de 25 años.

con el adelantado Miguel Lopez de Legazpi siruio muy bien en la pacificacion y conquista destas yslas hasta que ffue con la gente de Cebu que lleuo debaxo de su bandera la jornada del maluco donde teniendo cercada la fortaleça de los enemigos y al rrey de terrenate, de un balaço de una pieça de Hartilleria que dispararon de la ffortaleça le lleuaron la cauça y fue el primero que murio en seruicio de la ffe de dios nuestro señor. y de su magestad, y assi mismo dos Hermanos de Doña Beatriz ssorio su madre pues de las primeras pobladores que an benido a esta tierra, desde el año de setenta y Don Pedro de oseguera es el hijo mayor que dexo el dicho capitan Pedro de oseguera y eredo la encomienda de su padre que quando mas cobrara della ochocientos tributos $\mathrm{y}$ dellos paga la quarta por estar en parte que no ay doctrina y otros gastos que Hace cosoldados que ban a la cobrança que sacadas estas cargadas le queda bien poco y desso socorre a dos Hermanos a seruido a su magestad desde que tubo hedad para ello en todo lo que sea offrecido y se le a mandado con persona hacienda y calidad muy como cauollero.

que aunque tiene en las cedulas de encomiendo muchos mas Yndios jamas le an dado tributo por estar de guerra y de arte que si les enbia algun

Puede su magestad seruirsse del en cossas de guerra y justicia,

rrecaudo rresponden con lanças y pabeses diciendo que de aquella manera le daran el tributo y assi passa necessidad es hombre sin bicios virtuoso y merece que su magestad le haga merced. Sera de edad de veynteycinco años y puede su magestad seruirse del.-

el menor de santa cruz. El menor de santa cruz es hijo de uno de los soldados primeros. Siruio bien heredo la encomienda de su padre que le rrentara dos mill tributantes por no tener doctri- 
na paga la quarta. $Y$ aunque tiene otras cargas y costas de cobrança con lo que le queda y le abra rrentado quando tenga hedad para goçar de su hacienda tendra bien de comer para segun su calidad sera de hedad de diez y siete años.

el menor de domingo El menor de domingo de çuaço que ffue de los de cuaço primeros tendra setecientos Yndios $y$ antes mas que quitadas costas para segun su calidad, quando benga a gozar de su encomienda tendra con que passar.

Juan Martin cassado de Juan Martin es de los primeros a sido buen solda70 años do y Hombre de bien tendra ochocientos yndios que sacadas costas con lo que le queda y sus ynteligencias de trato tiene de comer es casado y de Hedad de 70 años.

Alonso de Henao, biudo

Alonso de Henao es de los primeros tendra otros de Hedad de 70 años. ochocientos yndios que sacadas costas con el rresto y hacienda y ynteligencias que tiene para segun su calidad le basta. Tendra setenta años.

Alvaro tineo vino año

Alvaro tineo bino muchacho a estas yslas el año de 86 tendra 30 años. de ochenta y seis casso con una yndia que ffue muger de matheo sanchez de los primeros de quien heredo una encomienda que cobra della mas de dos mill y quinientos tributos ques de las mejores de cebu. Tiene en parte della doctrina que sacadas costas le queda muy bastantemente de comer para lo poco o nada que a seruido.

El menor de Juan de El menor de Juan de Gamboa Heredo la encoGamboa sera de 14 años. mienda de su padre de que cobra mas de dos mill yndios que sacadas costas de doctrina y otras cossas quando benga a ser de hedad tendra muy bien de comer.

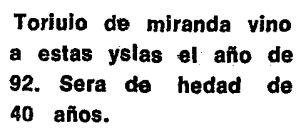

Toriuio de miranda vino a estas yslas el año de Nobenta $y$ dos a seruido en

Es hombre cuerdo y de quien su magestad se puede seruir.

algo y tiene encomienda de que cobrara mill tri-

Encomendole don francisco tello.

Antonio freyle passo a estas yslas afío de 80 . Tendra 40 años.

a tenido esta rrico y tiene bien de comer.
Antonio Freyle passo a estas yslas el año de ochenta con el governador don gonçalo ronquillo casso con muger que ffue de Juan de Gamboa. Tiene encomienda que con ella y ynteligencia que
Diole este rrepartimlento Don Francisco Tello.

Francisco Rodriguez de auila moderno. De hedad de 35 años.

do le basta.
Francisco Rodriguez de auila casso con una biuda queredo la encomienda de su primer marido que cobrara della mas de setecientos yndios para su calidad y ser moderno y lo poco que a serui- 


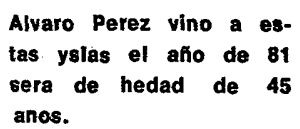

Alvaro Perez vino por cirujano el año de ochenta y uno casso con la muger que Puedeso del seruir su magestad en cosas de Justicia.

heredo la encomienda de su primer marido que aunque la mayor parte della no esta llana con lo que cobra y su ynteligencias tiene de comer.

Francisco de Molina vino el año de 85 . Tendra 40 afios.
Francisco de Molina vino a estas yslas el año de ochenta y cinco casso con mu-
Puede su magestad seruirse del en cosas de Justicia.

ger que ffue de Andres Duerto de quien ella heredo una encomienda que cobrara della mill tributos que con ellos y sus ynteligencias tiene harto de comer.

Pedro Hernandez de Leon isera de hedad de 36. Casado.
Pedro Hernandez de Leon es hijo de Juan Hernandez de Leon de los primeros y fue buen soldado. Heredo la encomienda de su padre que cobrara della como ochocientos yndios que con ellos y los tratos e ynteligencias que an tenido esta rrico y tiene sobrado de comer para su calidad y poco que a seruido.

Gaspar de los Rreyes. Gaspar de los Rreyes es de los antiguos tendra quinientos yndios de encomienda que sacados gastos le queda bien poco y con ello passa pobremente por ser cassado.

Pedro Mendez tendra 20 Pedro Mendez de sotomayor Hijo de Juan Mendez años. Casado.

de sotomayor Heredo la encomienda de su padre que fue de los primeros de que cobrara ochocientos tributos que para su calidad aunque su padre fue buen soldado y sirbio bien es hijo de una yndia y sobra lo que tiene.

El menor de parexa El menor de xpoval de parexa que fue de los primeros y buen soldado Heredo la encomienda de su nieto que cobrara ochocientos tributos que con ellos y lo corrido quando tenga hedad le basta para su calidad.

Don Luis de Velasco vino a estas yslas año de 80. Sera de hedad de 36 años. encomienda que dexo su padre que cobrara della mas de ochocientos tributos a seruido algo y para su calidad y de su muger y gasto de su ffamilia tiene escassamente de comer."

Fernandias de rriua deneyra vino a estas yslas el Fernandias de rriua deneyra año de nobenta con el governador Gomez Perez vino el año de 80 de Dasmariñas a seruido de alférez en este campo y
hedad de 34 años.

en la jornada de mindanao de capitan y sargento mayor es buen soldado casso con hija de alonso Osorio de los antiguos $\mathrm{y}$ benemeritos, con quien hubo un pedaço de la encomienda que dexo su padre que cobrara della seiscientos tributos que sacadas costa le queda poco para su sustento. 
Ffrancisco Alvarez de toledo es de los primeros que vino muchacho tendra 40 años.
Ffrancisco Alvarez de toledo es de los primeros tiene encomienda que cobrara della más de ochocientos tributos que para segun su calidad y auerse cassado con una yndia tiene con que passar.-

Otros Encomenderos ay en Zibu de Menor que por no

ser cossa de momento tratar dellos

no se ponen aqui

Los que tienen encomiendas en la ysla de Panay y su comarca son los siguientes.

Doña Margarita hija. del general Esteuan Rodriguez de Figueroa.
La menor del capitan Esteuan Rrodriguez de Figueroa. De los primeros que binieron a la conquista con el adelantado y siruio muy bien y yendo por Gouernador y capitan general a la conquista del rrio de mindanao le mataron los yndios del Heredo de su padre las encomiendas de Tibagua y guaz y libon que cobrara mas de tres mill tributos con que podra cassarse onrradamente quando tenga hedad para ello.

El Capitan Pedro Sarmiento bino a estas yslas el año de 66. Sera de hedad de mas de $\mathbf{5 0}$ años.
El Capitan Pedro Sarmiento vino a estas yslas el año de sesenta y seis a seruido muy bien a su magestad asi en la conquista

Puede su magestad seruirse del en cosas de guerra.

y pacificación destas yslas y despues en todo lo que se a ofrecido tiene encomiendas que cobrara dellas más de dos mill y quinientos yndios que con ellos y sus ynteligencias tiene bien de comer.-

Francisco de rriuera de los primeros. De hedad de más de 50 años.

$\mathrm{y}$ trescientos tributos que con ell mer.

Alonso de Herrera de los primeros cassado dera de hedad de afios.

Francisco de rriuera es de los primeros y a seruido muy bien en la conquista y pacificación destas yslas. Tiene encomienda que cobrara della mill que con ellos y sus ynteligencias tiene bien de coAlonso de Herrera es de los primeros a sido buen soldado tiene encomienda que cobrara nobecientos tributos que con ellos y el caudal que tiene segun su calidad tiene bien de comer.

Sebastian de Morales esta en estas yslas desde el año 72.

Sebastian de Morales hijo Gaspar Rruiz de Morales de los primeros del año de
Puede su magestad seruir del en cossa de guerra $y$ de justlcia.

setenta y dos siruio muy bien su padre de quien heredo una encomienda que cobrara della quinientos tributos que sacadas costas de doctrina le queda bien poco para el sustento de su muger y ffamilia y es hombre virtuoso y a seruido en lo que se a ofrecido y se le a mandado y merece le haga su magestad merced asi por los seruicios de su padre como por los suyos.- 


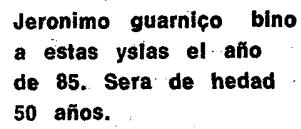

Jeronimo Guarniço vino a estas yslas el año de ochenta y cinco con el gouernador santiago de vera Puede su magestad iseruirse del en cossas de por mando de la capitana guerra y justicia.

casso con hija de Cristobal Leal a quien el padre en vida con veneplacito del gouernador rrenuncio la encomienda que tenia en el con que le quedasse para su sustento la quarta parte della. Cobrara más de mill tributos que con ellos y sus ynteligencias tiene de comer demas de que ya murio su suegro que lleuaua la quarta parte.

Anton de Xerez Montoro vino a estas yslas el año de 90 , sera de hedad de 30 años.
Anton de Xerez Montoro vino a estas yslas el año de nobenta casso con la muger que fue de Juan Xuarez de quien heredo la encomienda que cobrara della mill y treçientos tributos que para su ca-

lidad tiene bastantemente de comer.

Miguel Rodriguez bino a estas yslas año de 71 sera de hedad de más de 50 años.

El menor de aluaro de angulo de hedad de diez años.

Miguel Rrodriguez bino a estas yslas el año de setenta y uno es buen soldado y a seruido bien tiene encomienda que cobrara della ochocientos tributos con que tiene de comer.

El menor De Albaro de angulo que fiue de los primeros tiene encomienda que heredo de su padre que cobrara della setecientos tributos que con ellos $\mathrm{y}$ con lo que abran rrentado quando tengan hedad de gozarla tendra que comer.

El menor de antonio flores de hedad de 15 años.

El menor de Antonio Flores que fue su padre de los primeras y siruio muy bien heredo la encomienda de su padre que cobrara della mill y qui-nientos tributos que con ellos quando venga a ser de hedad de administrallos tendra bien de comer.

Ysidro de aro vino a estas yslas el afio de 90. Sera de hedad de 36 años.
Ysidro Sanchez de haro vino a estas yslas el año de nobenta con el gouernador Gomez Perez de Dasmari- tiene talento para que su magestad se sirua del en cossas de justicia.

ñas. Casso con Doña Leonor Xuarez muger que ffue de el capitan Juan Pablos de Carrión de quien heredo su encomienda que cobrara della mas de tres mill tributos con que tiene sobradamente de comer.

Ei Capitan Agustin de Arzeo vino a estas ys las el año de 80 sera de hedad de 50 afios.
El Capitan Agustin de Arzeo vino a estas yslas con compañia de soldados el año de ochenta con el gouernador Don Gonçalo Rronquillo. Casso con hi-
Puede su magestad seruirse del en cossas de

ja de Luis Perez soldado viexo de los primeros y guerra y de justicia.
que bien siruieron que heredo la encomienda de su padre que cobrara della mill trescientos tributos que con ellos y caudal que a llegado con sus ynteligencias tiene muy bien de comer. 
Diego Lopez de Baidepeftas de los primeros, de hedad de 60 y más años. casado.

El menor de Lope Rodifguez de hedad de 17 ahos. quando benga a ser de hedad para administrarlos tendra bien de comer.-

E Capltan Martin de Mendia bino el afio de 80 tendra 55 afos. ssido buen soldado tiene encomienda que cobrara della ochocientos tributos que con ynteligencias que a tenido y tiene le sobra lo que a menester.El menor de Lope Rrodriguez que ffue su padre de los primeros y buen soldado heredo su encomienda que cobrara della ochocientos tributos que

El Capitan Martin de Mendia bino a estas yslas el año de ochenta casso con ysauel de Villalobos que Puede su magestad seruirse del en cosas de

Diego Lopez de Baldepeñas es de lós primeros y a heredo la encomienda de su primer marido que justicia. cobrara della seiscientos tributos que con ellos y sus ynteligencias tiene de comer.

Gaspar de ysla bino a esta tierra el afio de 72 tendra 45 afios.
Gaspar de ysla bino a estas yslas el año de setenta y dos tiene dos pedaços de encomienda que cobrara dellas setecientos tributos a seruido algo y con ellos y ynteligencias que a tenido tiene con que passar es hombre de bien.

Los de asta aqui son los encomenderos que ay en las yslas de Cibu y de Panay de que se Puede Hacer caudal que para biuir en las dichas ysias obliga a poco gasto aunque de poco aca se an ydo encareciendo mucho los bastimentos y todo lo demas de la tierra para como solia de antes.

Los encomenderos que ay en la ciudad de Manila y su comarca son los que siguen.-

El Mariscal grauiel de rriuera es de los priEl Mariscal es de los meros tiene tres encomienprimeros tendra 60 anos. das de que cobrara ocho

Puedese su magestad seruir del en qualquler negocio de momento. mill tributos y con otras ynteligencias es el más rrico que ay en todas las yslas a seruido muy bien a su magestad.

\section{El Capitan Antonio do Cafiedo vino a estas ys- las el año de 67 sera de hedad de 55 afios. Repartiole Don Ffrancis- co Tello selscientos yn- dios.}

cobrará más de mill tributos. $\mathrm{Y}$ con sus ynteligencias tiene de comer.
El maestro de campo Pedro de Chaves passo a estas yslas el año de 72. Sera de hedad de 48 años.

Proviole Don Francisco Tello en el officlo do
El Capitan Antonio de Cañedo vino a estas yslas el año de sesenta y siete a seruido bien en la conquista tiene encomiendas de que

Puede seruirse del su magestad en cossas de. guerra y justicia.
El Capitan y maestro de campo Pedro de Chavez vino el año de setenta $y$ dos con muy buena compañia de soldados y a seruido muy bien en todas las ocasiones que se an offre-

Puede su magestad seruirse del en cossas de guerra y de justicia y de todo momento de ymportancla. cido de ymportancia y no a sido gratificado de sus 
Maestro de campo por fin $y$ muerte de Dlego Ronqullo. seruicios porque la encomienda que tiene la truxo su primera muger de que cobra mill y ochocientos yndios que quitadas las costas de doctrina y otros gastos no tiene para el gasto de su casa y familia ques mucho para el aunque le es alguna ayuda el Salario del oficio de maestro de campo que se le a dado bien merecido y se lo deue su magestad confirmar.

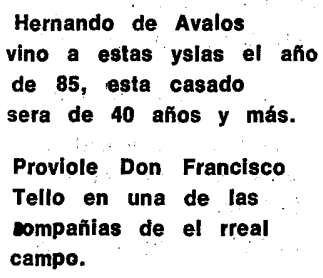

brara della mill y trescientos tributos que con ellos y sus ynteligencias tiene bien de comer. esta cassado.

\begin{abstract}
El Capitan Don Juan de Camudio vino a estas yslas el año de 85 tendra

El Capitan Don Juan de Çamudio vino a estas yslas el año de ochenta y cinco y torno a la nueva españa y boluio a estas yslas esta campo casso con doña tan Juan de Moron de quien heredo una encomienda que cobra della mas de tres mill quinientos tributos que con ellos y sus ynteligencias esta rrico.
\end{abstract}

Don Juan Rronquillo $y$ Don Gonçalo Ballesteros pasaron a estas yslas año de 80 tendrá cada uno 36 años son cassados.

Don Juan Ronquillo es Alguazil de la real audiencia.
Don Juan Rroquillo y Don Gonçalo Ballesteros pasaron a estas yslas el año de ochenta con el gouernador Don Gonçalo Rronquillo an seruido en 10 que se les a mandado tienen anbos de por mitad una encomienda de que cobraran mill y ochocientos tributos que sacadas costas en lo que les queda no tienen con que sustentarse conforme a la calidad de sus personas aunque Don Juan lleua agora gajes de su magestad por general de las galeras que les ayuda.
El Capitan Juan de Alçega passo a esta yslas

EI Capitan Juan de Alcega passo a estas ys- el año de ochenta con el gouernador Don Gonçalo Rronquillo a seruido muy 
las el año de 80 tendra 40 antos.

bien en lo que se le a mandado tiene una encomienda que cobra della mill tributos que con ella y sus ynteligencias tiene bien de comer esta cassado.-

El Capltan Tome de la ysla vino el afio de 70 sera de hedad de 45 aftos.

El Capitan Don Francisco : Mendoça passo a estas. yslas el afio de 90 tendra 40 afios. Casado.
El Capitan Tome de la ysla vino a estas ysias el año de setenta y a seruido bien tiene encomienda que heredo de su padre que cobra dos mill tributos della con que tiene bien de comer.

El Capitan Don Francisco de Mendoça passo a estas yslas con el gouernador Gomez Perez y truxo Puede se magestad seruirse del en cosas de guerra $y$ de justlcla.

Compañia de soldados cas-

so con Doña Mariana que heredo la encomienda de su marido el capitan Vergara que cobrara della setecientos tributos que sacadas costas tiene estrechamente de comer.

El Licenciado Gomez de Bustamante de andrada

EI licenclado Gomez de Bustamante passo a estas yslas el año de 90 sera de hedad de 50 ấos.

vino a estas yslas el año

de nobenta y se le encar-

go vissitase las provincias

ed pintados la qual hizo bien casso con doña Ma

ria de Aguilar que sucedio en la encomienda de su primer marido diego aleman que cobrara della quinientos tributos que sacadas costas le queda bien poco que conforme a su calidad no tiene para sustentarse.

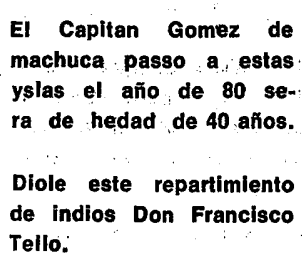

El Capitan Gomez de machuca passo a estas yslas Puedese su magestad seruirse del en cossas con el gouernador Don Gonuenador Don Gonçalo Rronquillo el año de 80 y truxo una compañia siruio el officio de thesorero y factor el tiempo que Gouerno Gomez Perez de Dasmariñas tiene encomienda que cobra della mill ducientos y mas tributos que con ellos y sus ynteligencias y Hacien-

da que tiene esta rrico.

El Capitan Francisco de Mercado passo a estas yslas el año de 80 sera de hedad de 45 afios.
El Capitan Ffrancisco de Mercado passo a estas yslas con el gouernador don Gonçalo Rronquillo tiene encomiendas que cobrara de-
Puedese su magestad serruirse del en cossas de guerra y justicia.

llas mill y quinientos tributos que sacadas costa con ellas y con sus ynteligencias tiene sobradamente de comer.

Juan de Hermosa de mas de 22 affos. Sera de hedad de 50 años.

que le sobra para su calidad a seruido bien y es muy buen hombre.
Juan de Hermosa a que vino a estas yslas más de veinte $\mathrm{y}$ dos años tiene encomienda y hacienda con Puedese su magestad seruirse del en cossas de guerra. 
El Capltan Gaspar Osorio de moya vino a estas yslas el año de 67. Sera de hedad de mas de 50 afios.

El Alferez Franclsco del Castillo passo a estas yslas el año de 85 sera de hedad de 50 afios.

Goza de los: 500 yndios por conclerto que hizo con el ospital real a quien se los dio Don Francisco Tello.
El Capitan Gaspar Osorio de moya vino a estas yslas el año de sesenta y siete a seruido bien tie ne encomienda que cobrara della más de seiscientos tributos que con ellos y con sus ynteligencias esta rrico y con que pasar Honradamente.

El Alferez Francisco del Castillo es maestro mayor de las Herrerias de su magestad passo a estas yslas el año de ochenta y cinco sera de hedad de cinquenta años tiene dos pedaços de encomiendas que cobrara dellas mill y quinientos yndios que con ellas y mill pesos que tiene de salario de su officio tiene muy bastantemente de comer.

El menor del contador Andres Cauchela.

El menor del contador Andres Cauchela tiene dos pedaços de encomiendas que heredo de su padre

que cobrara dellas mill y ducientos tributos que con ellos quando venga a ser de hedad tendra bien de comer.

El Capitan Juan de Bus. tamante passo a estas yslas a 18 años casado y de hedad de más de 60 años.

El Capitan Juan de Bustamante es antiguo en las yslas de mas de treynta y ocho años a esta parte y siempre a seruido muy bien asi en cossas de guerra como de justicia y los diez y ocho en estas yslas en cossas ynportantęs tiene un pedaço de encomienda en compañia de otro que cobrara de su parte quatrocientos y cincuenta tributos que sacadas costas no tiene nada para segun su calidad cassa y ffamilia y bibia pobremente si su magestad no le ubiera hecho merced en gratificación de sus seruicios de la contaduria de su rreal hacienda destas yslas que queda siruiendo es sujeto aunque hombre mayor para seruir a su magestad en cossas de momento de guerra y de justicia.- es hombre exemplar y de Es sujeto aunque Hom bre mayor para seruir a su magestad en cos'sas de momento de guerra $y$ de justlcia.

buena vida y benemerito de qualquier merced que su magestad le Haga

Domingo Hortiz dechagoya passo a estas yslas año de ochenta y uno casso con muger que fue de anton sanchez de Harmas $y$ eredo un pedaço de

Puede su magestad seruirse del en cosas Justicla y papeles. encomienda de juanes de arigue su segunda marido que cobra della quatrocientos y cincuenta tributos que con ellos y con aver servido el officio de contador en la bacante despues de la muerte del contador cauchela y sus ynteligencias esta rrico.

Alonso de Carrion passo a estas partes el afio de 74 es de hedad de 50 años. Casado.
Alonso de Carrion vino a estas yslas el año de setenta y quatro a sido buen soldado $\mathrm{y}$ seruido en lo que se a offrecido tiene un pedaço de encomienda en compañia de su magestad que cobrara della quatrocientos tributos que sacadas costas le queda bien poco para el sustento de su persona. 
El Capltan Don Juan de la pefia vino nifio con su padre el afio de 77 tendre 30 afios.
El Capitan Don Juan de la Peña heredo de su padre una encomienda que cobrara setecientos tributos que sacadas costas le queda poco para el sustento

de su cassa persona y ffamilia demas de que ba cada dia en desminuycion y no cobra agora trecientos.

El Capltan Diego del El Capitan Diego del Cas- Puede su magestad ser-
Castillo vino a 18 afios
sera de hedad de 50
años.
redo una enconquillo con compañia de soldados casso con
ffuera de ellos.
ffuera de ellos.

El Capitan Luis daualos passo a estas ystas el año de 85 tendra hedad de 32 años. lina Çarate muger que ffue de Don Pedro de Aguirre de quien heredo una

El Capitan Luis Daualos hijo del licenciado aualos oy-

Puedese su magestad seruirse del.

dor que fue destas yslas passo con su padre a ellas el año de ochenta y cinco casso con Doña Cataencomienda que cobrara della setecientos tributos que sacadas costas para segun su calidad gasto de cassa y ffamilia lo passa estrechamente en especial que a ydo en gran disminuyción.

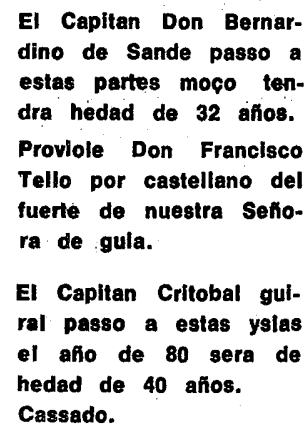

El Capitan Don Bernardino de Sande vino con el doctor Ffrancisco de sande su hermano gouernador que ffue en estas yslas el año de setenta y cinco tiene encomienda que cobra más de dos mill tributos que sacadas costas le queda con que sustentarse aunque ba la encomienda cada dia en disminuycion y esta pobre.

El Capitan Cristobal guiral passo a estas yslas con el governador Don Gonçalo Rronquillo casso con Doña Ynes de Monterrey que heredo una encomienda de Don Antonio Joffre su primer marido que cobra della dos mill yndios que sacadas costas les queda bastantemente de comer.

El Capitan Cristoval de asqueta esta en estas yslas desde el afio de 75 sera de hedad de quarenta afios.

tiene una companila de paga por nombramiento de don Francisco Tello.

Pedro de Ortega passo a estas partes el ano do 85 sera de hedad do 45 ahos.
El Capitan Cristoval de asqueta vino a estas yslas con el gouernador Francisco de

Puede su mageatad seruirse det en cossas de guerra. lo que se a offrecido y se le a mandado tiene una encomienda que cobra della ochocientos tributos que sacadas costas con el rresto y los gaxes que se le dan de Capitan de ynfanteria lo passa moderadamente.

Pedro de Ortega passo a estas partes el año de ochen-

Purede su magestad serta y cinco casso con doña Ana de Herrera que he- 
redo la encomienda de su primer marido Juan de. argumedo que cobrara mill y cien tributos que con ellos y hacienda que: le quedo tiene sobradamente de comer.

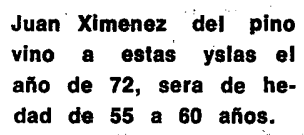

butos que sacadas cost tenido y tiene esta rrico y tiene bien de comer.

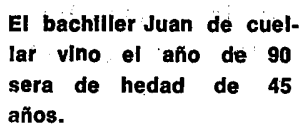

Juan Ximenez del pino vino a estas ysias el año de setenta y dos a sido buen soldado tiene un pedaço de encomienda en compañia de otra de su magestad que cobrara de su padre quinientos tri-

El bachiller Juan de cue- Puede su magestad serllar vino a estas yslas en uirse del en cossas do año de [no] benta con el papeles.

governador Gomez Perez de Dasmariñas y por su

secretario casso con Doña Rruffina muger que fue de Aguilar de quien heredo una encomienda que cobrara della mil tributos que aunque tiene más yndios no estan llanos que con ellos y caudal que tiene tiene con que pasar.

Otras encomiendas y encomenderos ay de que no ay que hacer memoria dellas ni dellos y anssi se queda esto aqui para lo de Manila.

En la ciudad de Caceres ques la provincia de Camarines ay los encomenderos siguientes.

El capitan Pedro de arceo vino el año de 87 sera de hedad de $\mathbf{4 0}$ años.
El Capitan Pedro de arceo vino a estas yslas con compañia de algunos soliados el año de ochenta y siete casso con Doña Margari-
Puede su magestad seruir del en cossas de ta de Contreras muger que fue de Juan de Guzman su primer marido de quien heredo una encomienda que cobra della más de mill y ducientos tributos que con ellos y los gaxes de capitan de ynfanteria que sirue tiene onradamente de comer.

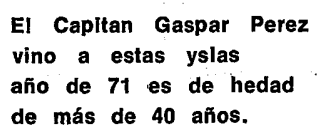

pedaços de encomienda que cobra dellas nobecientos a mill tributos que con ellos y sus ynteligencias tiene de comer.

EI Rregidor Francisco de carate vino a estas yslas el año 86 , de hehedad de 30 años. Cassado.

Es Regidos por nombramiento de Don Francisco Tello.

Diego Diaz marmolexo es de los primeros de hedad de 40 años. Cassado.
El Regidor Francisco de Çarate vino a estas yslas el año de ochenta y Puedese' su magestad seis tiene encomienda que seruir del.

hubo con Doña Catalina de oseguerra que cobra della ochocientos tributos que sacadas costas le aueda vien poco para segun su calidad gasto de cassa y ffamilia es hombre pobre y virtuoso.-

Diego Diaz marmolexo es de los primeros a seruido bien tiene encomienda que cobra della seiscientos tributos que con ellos y el salario de en- 
Encomendole Don Francisco Tello en tresclentos yndios.

Rodrigo Cerffate es de los antiguos de hedad de 60 años cassado.

Juan de yepes es de los antigulos de hedad de 50 años. Cassado.

Pedro cid vino a estas yslas el afio de 77 de hedad de 40 años. Cas. sado.

tretenimiento de capitan de harmeria de su magestad que le he dado tiene con que passar.-

Rodrigo Serffate de los antiguos tiene encomienda que cobra della seiscientos tributos que con ellos y hacienda que tiene lo passa onradamente.Juan de Yepes soldado de los antiguos tiene encomienda que cobra della seiscientos tributos que con ellos y alguna hacienda que tiene, tiene con que passar.

Pedro cid vino a estas ys- Puede su magestad serlas el año de setenta $y$ uirse del en cosas de siete a seruido en lo que

se le a mandado casso con muger que ffue de thomas de aro de quien heredo encomienda que cobra dellas seiscientos tributos con que sacadas costas tiene lo que a menester para su sustento-

El menor de Anton SanEl menor de anton Sanchez de armas heredo de su padre encomienda que cobra della seiscientos chez de armas.

y lo caydo para quando tenga hedad tendra con tributos que con ellos y 10
que passar onradamente.

El menor de Melchor de El menor de Melchor de Torres heredo encomienTorres.

da de su padre que cobra mill tributos que quando venga a ser de hedad para administrallos tendra bien de comer.-

Sebastian Garcia vino el año de sesenta y siete

Sebastian Garcla vino el año de 67 es de hedad de 60 afios cassado.

a seruido muy bien en la pacificación tiene encomiendas de que cobrara sete-
Puedese seruir. su magestad en cossa de guerra.

cientos tributos que sacadas costas para el gasto de su familia y muchos hijos que tiene lo passa pobremente y merecen sus servicios que su magestad le haga merced.

Pedro de Salazar vino el año de 71 es de hé. dad de 60 años: Cassado.

Pedro de Salazar vino a estas yslas el año de setenta $y$ uno a seruido bien

tiene encomienda de que cobra mas de seiscientos tributos que sacadas costas con ellos y ynteligencias y hacienda que tiene lo passa onradamente.

\footnotetext{
Rodrigo arias Xiron vi. no. el año de 83 sera de hedad de 30 años.
}

Rodrigo Arias Xiron vino con su padre a estas yslas el año de ochenta y Puedese seruirse su matres casso con hija de Vi- gestad del.

llanueva que heredo la encomienda de su padre de que cobra mas de seiscientos tributos que con ella y sus ynteligencias tiene que passar.

Juan Arias Xiron passo a estas yslas el año de 83 es de hedad de 28 años. Cassado.

Juan Arias Xiron passo a estas yslas el año de ochenta y tres casso con marì nuñez que heredo la encomienda de Gregorio uirse del. 
Sanchez su marido que cobra della mas de mill y ducientos tributos que sacadas costas le queda muy bien de comer.

Diego de Montoro vino el afio de 75 es de hedad de 50 afios.
Diego de' Montoro vino a estas yslas el año de setenta y cinco tiene encomienda que cobra della más de seiscientos yndios que con ellos y otras ynteligencias y trätos que siempre a teniđo esta rrico.

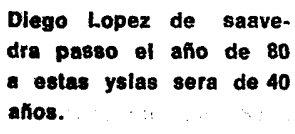

Don Juan Pimentel hijo de Alonso Pimentel de los

Don Juan Pimented, su padre de los antiguos de hedad de 20 ańos. Cassado. antiguos heredo la encomienda de su padre que cobra della setecientos tributos que con ellos y hacienda que le quedo tiene con que passar honrradamente.

El menor de Cristobal Sanchez de 17 años. El menor de Cristobal Sanchez que ffue de los primeros heredo de su padre una encomienda que cobra della más de ochocientos tributós.

Los encomenderos y encomiendas que ay de que hacer memoria son las que se an puesto hasta aqui porque aunque ay otras son de menos $\mathbf{y}$ no ay para que hacer caudal dellas ni de los que las poseen.

Que los encomenderos, atras rreferidos que biben en Zibu, Camarines y Panay y estan alli poblados salbo los de Manila tienen poco gasto porque las más costas de comida para el sustento hordinario se las traen de sus encomiendas y les questa barato y las obligaciones pocas porque biben y se tratan como en aldeas, lo de Manila es costosso por estar el audiencia rreal y el governador y capitan General en ella.

$Y$ porque se [en blanco] su magestad de todo Pondra aqui las encomiendas questan en su rreal caueça, y los, tributos que se cobran dellas que son los que siguen.

Vitis y lubao da cinco mill y treynta y nueve tributos y medio $\mathbf{5 . 0 3 9}$

Pueblo de castilla treynta y cinco tributos.

La costa y tondo y puerto de cauite tres mill quatrocientos y treynta tributos.

Capa ciento y cincuenta tributos.

Lunban Tayabas pacilemarata en la Laguna dos mill y quatro $\begin{array}{ll}\text { cientos } \mathrm{y} \text { quarenta } \mathrm{y} \text { siete tributos. } & \mathbf{2 , 4 4 7}\end{array}$

Nayun setecientos sesenta y quatro tributos.

Calilaya quatrocientos $\mathrm{y}$ veinticynco tributos, digo quatrocientos $y$ quarenta $y$ siete tributos.

Caraya quatrocientos $\mathrm{y}$ veintycinco tributos. 
Maragondon trecientos y diez y nueve tributos. $\quad 319$

Los baxos de Tuley quinientos y ochenta tributos. $\quad 580$

Mindoro luban y elin y baco dos mill y treynta y quatro tri$\begin{array}{ll}\text { butos. } & 2.034\end{array}$

Moron en la Laguna quatrocientos y treynta y quatro tributos. 434

$$
\text { tributos } \overline{16,104}
$$

Estos son los tributos que dan a su magestad en la comarca desta ciudad de Manila.

Fn la provincia de Camarines en caueça de su magestad los que siguen.

Mina laba y laga labo aquisete mauban y costa de vicayas ybalon nabua tres mill y ochocientos y cinuenta y nueve tributos.

En la ysla de Panay.

el rrio de arau dos mill y ducientos y cinquenta y cinco tributos.

El pueblo de sogor ochenta tributos.

Panay y braço de mayo setecientos y setenta y cinco tributos. $\quad 775$

Ajur y labango seis cientos y ochenta tributos.

En Cebu.

Conpote y Cagayan ciento y nobenta y cinco tributos 195

En Ylocos.

El valle de dinglas setecientos y quarenta y siete tributos. $\quad 747$

tributos $\overline{942}$

Los encomenderos de la ciudad de Manila y sus comarcas y de

Ylocos cobraran quarenta mill tributos poco mas o menos 40,000

Los de Zibu y sus comarcas veynte mill tributos. $\quad 20.000$

Los de la ysla de Panay veinte y un mill tributos. $\quad 20.000$

Los de la ciudad de Caceres y provincias de Camarines trece mill tributos.

Los de Cagayan cinco mill tributos esto es poco mas o menos porque unos años se cobra mas y otros menos y este presente año.

tributos. $\frac{5,000}{99,000}$

Hay quatrocientos mill yndios christianos, y ynfieles sin numero en las yslas Phelippinas que tienen dada la obediençia todos Al Rei ntro. señor.

\section{CARATULA DE ARCHIVO}

Memorial de las Personas benemeritas que ai en las yslas Phelippinas y los que tienen ya gratificacion de sus seruicios y la rrenta y hacienda que cada uno tiene y los subjetos y partes de todos. $Y$ asi mismo 
los yndios christiano e ynfieles que ai; y que tributos tiene el Rei nuestro señor y Particulares.

No. 2

Memorial De las personas venemeritas destas yslas Filipinas que an seruido a su magestad en la Reduçion, pacificacion y conseruacion dellas $\sin$ que se les aya dado gratificacion de sus seruicios.

E) capitan Francisco Rodriguez. ros conquistadores destas yslas a treinta $\mathrm{y}$ siete años que sirue en ellas auentajadamente en su reducion pacificacion $\mathbf{y}$ conseruacion en cargos honrados de que a dado buena quenta y en todo este tiempo no a sido gratificado en más de seiscientos tributos y conforme a la casa y familia que tiene a sus honrados meritos y servicios y a la calidad De su persona a menester ser acreditado con mas uentajas.

Alferez El alferez Geronimo de cuellar a veinte y quatro Geronimo de Cuellar. años que sirue a su magestad en la Reducion pacificacion y conseruacion de dichas yslas en las entradas pacificaciones y castigos que el dicho tiempo se an ofrecido a que a acudido como muy buen soldado no tiene ningunas gratificacion de sus seruicios merece ser gratificado.

Alferez

Alonso Farfan.

El alferez Alonso Farfan a treinta años que esta siruiendo a su magestad en la Reducion pacificacion y conseruacion de dichas yslas $y$ en dicho tiempo se a hallado en muchas entradas castigos y pacificaciones en que a seruido muy bien como buen soldado es persona de calidad de buenas partes no tiene ninguna gratificacion de sus seruicios merece ser premiado dellos.

Antonio de Pastrana.

Antonio de pastrana a veinte y quatro años que sirue a su magestad en la Reducion pacificacion y conseruacion de dichas yslas y en dicho tiempo se a hallado en muchas conquistas entradas y pacificaciones en las quales a seruido como muy buen soldado no tiene ninguna gratificacion esta pobre y merece se le haga merced.

El Capitan Alonso de

altra.

El Capitan Alonso de altra a treinta años que sirue a su magestad en la Reducion pacificacion y conseruacion de dichas yslas $y$ en dicho tiempo se a hallado en muchas ocasiones de guerra de la conquista de dichas yslas y en la defensa dellas contra el corsario Limaon y ultimamente el año de noventa y seis y fue a la pacificacion de la ysla de Mindanao por capitan de la Artilleria no se le a hecho ninguna gratificacion merece le sea hecha.

Diego de Fuentes

Diego de Fuentes a seruido a su magestad veinte y dos años en la pacificacion de dichas yslas y en dicho tiempo se a hallado en muchas entradas pacificaciones y castigos y en la defensa de la prouincia de Cagayan. Contra los Japonis cosarios que la querian ocupar donde se señalo peleando balientemente en la de- 
fensa de una nagalera que fue parte para que los dichos enemigos no la ganasen. No tiene ninguna gratificacion esta muy necesitado mereçe que su magestad le haga merced.

Bernerdino de olarte. Bernardino de olarte a veinte $\mathrm{y}$ quatro años que sirue a su magestad en la Reducion pacificacion $y$ conseruacion de dichas yslas en todas las ocasiones que se an ofrecido en las quales a seruido como muy honrrado soldado no se le a hecho ninguna gratificacion esta pobre y merece ser gratificado.

Francisco Muñoz.

Francisco Muñoz a veinte y cinco años que sirue magestad en la Reducion pacificacion y conseruacion de dichas yslas $y$ en dicho tiempo a acudido a muchos castigos y pacificaciones en que a seruido muy bien no se le a hecho ninguna gratificacion merece ser gratificado.

Alferez Juan Nuñez.

El alferez Juan Nuñez a Treinta años que sirue a

su magestad en la Reducion pacificacion y conseruacion de dichas yslas a todo lo qual a acudido como muy buen soldado no tiene niguna gratificacion esta muy pobre cargado de muger y hijos merece ser premiado de sus seruicios.

Don Matlas de Landecho

Don Matias de Landecho hijo del licenciado landecho presidente que fue de la Real audiencia de guatimala a veinte y quatro años que paso a dichas yslas a seruido a su magestad y en dicho tiempo se hallo en la conquista de $\mathrm{Ca}(\mathrm{ga}) \mathrm{yan}$ y a hecho otras jornadas a castigos y pacificaciones en cargos honrresos de que a dado buena quenta. $Y$ ultimamente aviendo sido ymbiado en seruicio de su magestad a la nueva españa fue proveydo por Don Luis de Velasco visorrey della por general de la armada de dicho nueva españa es persona de calidad y de ynportancia para el seruicio de su magestad no tiene ninguna gratificacion y merece que su magestal de haga merced.

Capltan Pedro

Yñiguez de medrano. Capitan Pedro Yñiguez de medráno a más de veinte años que esta siruiendo a su magestad en la rreducion pacificacion y conseruacion de dichas yslas hallandose en muchas entradas castigos y pacificaciones encargos calificados de que a dado buena quenta y ultimamente por nombramiento de Don Luis Perez Dasmariñas siruio oficio de tesorero de la Real hacienda tiempo de dos años. No tiene ninguna gratificacion de sus servicios. Es persona de calidad y de provecho para el seruicio de su magestad en officios de guerra justicia y hacienda y esta casado con hija de conquistador y esta gastado merece que su magestad le haga merced.

Capltanes Antonio y

Luis de Avalos.
Los capitanes Antonio y Luis de Avalos hijos del licenciado avalos oydor que fue de esta rreal audiencia pasaron con sus padres a seruir a su magestad a dichas yslas el año de ochenta y quatro y el dicho tiempo en seruicio con sus armas y criados en lo que se a ofrecido y en cargos de Justicia de que an dado 
buena quenta. Estan pobres no tienen ninguna gratificacion de sus seruicios merecen se les haga.

Pedro Patino. Pedro Patiño a veinte años que sirue a su magestad en dichas yslas como muy buen soldado en la rreducion pasificacion $y$ conseruacion dellas no tiene ninguna gratificacion merece que su magestad le haga merced.

Franclsco Lopez.

Francisco Lopez a que sirue a su magestad treinta años en la guerra como muy buen soldado en la Reducion y pacificacion de dichas yslas esta privado de la vista corporal no tiene ninguna gratificacion merece ser gratificado.

Capitan Pedro del

El capitan Pedro del Castillo Perona a veinte años Castlilo Perona. que esta siruiendo a su magestad en dichas yslas en la Reducion pacificacion y conseruacion dellas en cargos de guerra y de justicia de que a dado buena quenta es persona de calidad esta pobre no tiene ninguna gratificacion. Merece ser gratificado.-

Luis Alonso

Luis Alonso soldado de treinta y cinco años de seruicio en la guerra en la pacificacion y conser-

uacion de dichas yslas no tiene ninguna gratificacion. Merece ser gratificado.

Estevan de Marquina. El alferez estevan de marquina a diez y ocho años Alferez que paso a seruir a su magestad a dichas yslas $y$ en este tiempo a seruido en 10 que a ofrecido con sus armas y criados y encargos de justicia y pluma para los quales es muy suficiente. Esta cassado con hija de conquistador no tiene ninguna gratificacion merece ser gratificado.

Capitan

Hernan Sanchez.

El capitan Hernan Sanchez a diez y seis años questa siruiendo a su magestad en dichas yslas en la pasificacion y conseruacion della en cargos de guerra y de justicia de que a dado buena quenta no tiene ninguna gratificaçion esta pobre y merece ser gratificado.

Benito de Mediola. El Capitan Benito de Mendiola a veinte años que Capitan asiste a seruir a su magestad en dichas yslas con sus armas y criados y en cargos de justicia y pluma para lo qual es muy suficiente tiene casa y familia no tiene gratificacion de sus servicios merece que su magestad le haga merced.

Capitan Francisco El capitan Francisco Navarro arrieta a diez y sieNavarro Arrieta. te años que sirve a su magestad en dichas yslas en cargos de guerra y de justicia de que a dado buena quenta tiene casa y familia no se le a hecho ninguna gratificacion esta pobre y merece ser gratificado.

Diego de Santa Cruz. Diego de Santa Cruz a veinte y cinco años que asiste en dichas yslas y a seruido a su magestad en lo que se a ofrecido en oficios de justicia no tiene ninguna gratificación esta pobre y merece ser gratificado. 
Juan de Campos.

Juan de Campos a diez y seis años que sirue a su magestad en dichas yslas como muy buen soldado en la pacificacion y conseruacion dellas no tiene gratificacion merece tailue su magestad le haga merced.

Alferez Don Luis de El alferez don Luis de Ballesteros a nueve años Ballesteros.

que esta siruiendo a su magestad en dichas yslas continuamente en la guerra y en las ocasiones que en este tiempo se an ofrecido a acudido como muy honrrado soldado no se le a hecho ninguna gratificacion esta pobre merece ser gratificado.

Alferez El alferez Pedro. Perez de segura a diez y siete Pedro Perez de segura. años que paso a dichas yslas a seruir a su magestad y en ellas a seruido en lo que se le a ordenado y ultimamente dicho governador le nombro por capitan de una galeota sin sueldo no tiene ninguna gratificacion esta cassado y pobre merece que su magestad le haga merced.

Miguel Nuñez.

Miguel Nuñez a treinta años que sirue a su magestad en dichas yslas en todo to que en ellas se a ofrecido en este tiempo esta pobre y no tiene ninguna gratificacion merece ser gratificado.

Alferez Juan El alferez Juan Ramos de Renteria a diez y seis Rramos de Rrenteria. años que sirue a su magestad en dichas yslas como muy buen soldado y en las ocaçiones de guerra que se an ofrecido en este tiempo no tiene ninguna gratificacion merece se la haga merced.

Alferez Juan Gallardo... El alferez Juan Gallardo a diez y siete años que sirue a su magestad en dichas yslas en la pacificacion y conservacion dellas como buen soldado en todas las ocaçiones que se an ofrecido en este tiempo no tiene ninguna gratificacion de sus seruicios es cassado y esta pobre merece ser gratificado.

Alferez El Alferez Francisco de Herrera a diez años que Franclsco de Herrera. sirue a su magestad en dichas yslas en las ocasiones de guerra que se an ofrecido como muy buen soldado no esta: gratificado de sus seruicios merece que su magestad le haga merced.

Alferez $\quad$ El Alferez Basco Gutierrez a veinte años paso a Basco Gutierrez. dichas yslas a seruir a su magestad y en este tiempo a acudido a todo lo que se a ofrecido en la conservacion de dichas yslas es mosso virtuoso y buen soldado no tiene ninguna gratificación de sus servicios. Merece se le haga merced.

Alferez Juan Berdugo. El alferez Juan Berdugo a veinte años que sirue a su magestad en dichas yslas en la pasificacion $y$ conservacion de ellas y ultimamente aviendo la jornada de Cagayan a su pasificacion el año pasado de ochenta: y quatro perdio el braco derecho en servicio de su magestad no tiene gratificacion de sus servicios esta pobre y merece ser gratificado.

Capitan

Bernardo de Castro.
El Capitan Bernardo de Castro que a quinze años que sirve a su magestad en la pacificación y con- 
servación de dichas yslas con aprovación en cargos de guerra y de justicia no tiene ninguna gratificación esta necesitado tiene casa y familia merece ser gratificado.

Blas Escoto de Touar.

El Licenciado Blas Escoto de touar a siete años que paso a seruir a su magestad a dichas yslas $y$ en este tiempo a servido con sus armas y criados en lo que se a ofrecido es persona de calidad y buenas letras tiene casa y familia no tiene ninguna gratificacion podra ser de provecho en qualquier oficio de justicia que se le encargue.

\section{N. ${ }^{0} 3$}

Lista y Memoria de los vezinos destas Yslas Philippinas que no estan encomendados y el tiempo que cada uno a que esta en ellas por abecedario.

\section{A}

El Alferez Alonso Bienbengud Passo a estas El alferez Alonso yslas el año Passado de noBienbengud esta pobre. benta en plaça de alferez

Puedese vuestra magestad seruir del en cosas de guerra y justicia. de ynfanteria y a servido Personalmente en las ocasiones que se an ofrecido en su tiempo es hombre virtuoso y de quien vuestra magestad se puede seruir en cosas de guerra. Tiene quarenta años de hedad esta pobre.

El capitan Alonso Sanchez adalid tiene : algun caudal
El Capitan Alonso Sanches adalid Passo a estas yslas el mismo año a seruido en lo que en su tiem-
Puede vuestra magestad serulr del en cosas de guerra.

po se a ofrecido y señaladamente en las galeras vuestra magestad que le encomendo Gomez Perez Dasmariñas puedese vuestra
seruir del en cosas de guerra. Tiene quarenta y quatro años.

El Capitan Agustin de Lesaca esta pobre. Hale Don Francisco Tello ocupado en officlos de justicia.
El Capitan Agustin de Lesaca Passo a estas yslas el año Passado de nobenta $\mathrm{y}$ dos a seruir a vuestra magestad lo qual a contiPuedese vuestra magestad seruir de el. de guerra y justicla.

nuado todo el tiempo én los oficios de guerra y de justicia que se le an encargado es persona de quien vuestra magestad se puede seruir en los dichos oficios tiene caudal aunque poco y a ssido toda su vida Buen soldado tendra quarenta años.

Alonso Rodenas fuenllana. Passo a estas yslas con El Alferez tiene de comer. el governador Gomez Perez Puedese vuestra magesel año de nobenta y uno tubo a su cargo una de tad seruir del.

las banderas deste pressidio con su paga tiempo de seis años casose y tiene de comer es de hedad de treinta y seis años.

Capitan Antonio de Avalo Tiene caudad. Anda ocupado en cosas de justicia.
Antonio de avalos Hijo del Licenciado Melchor de aualos oydor que fue de la primera audiencia Real que Puedese vuestra magestad seruir del.

rressidio en estas Yslas. Passo a ellas con sus Pa- 
dres y Hermanos el año Passado de ochenta y quatro a seruido en lo que se a ofrecido en su tiempo y en oficios de justicia que se le an encargado. Tiene caudal sera de hedad de quarenta y seis años.

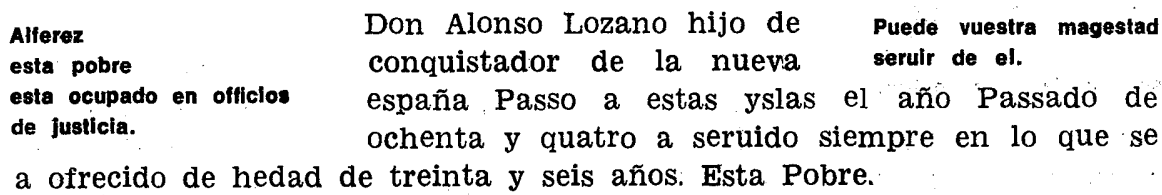

Alonso Hernandez Alonso Hernandez soldado vino a estas yslas con tiene algun caudal. el governador Don Gon- Puede vuestra magestad zalo Rronquillo el año de ochenta a seruido en seruirse del. las ocasiones que se an ofrecido tiene algun caudal aunque poco de hedad de quarenta años.

Alonso Henandez Alonso Hernandez Mataco Passo a estas yslas el mataco. año Passado de nobenta y seis a seruido en la guardia y defensa desta ciudad personalmente en lo que se a ofrecido tiene caudal con que passar y mas de quarenta años de hedad.

Alonso de Estrada Alonso de Estrada passo a estas yslas el año pastiene caudal. sado de ochenta $y$ siete $y$ Boloui el nobenta a asistido como los demas a la defensa desta ciudad tiene caudal con que pasar y cinquenta años de hedad.

Antonio de Rrobles

tiene caudal.

treinta años.

Antonio Lopez.

Esta pobre

esta pobre.

Alonso caro tlene caudal.

Alonso caro cerezo passo a estas yslas año de ochenta. Es casado tiene buen caudal con que passar y de hedad de quarenta años.

Alvaro de la mata tiene caudal.

Alvaro de la mata passo a estas yslas con el governador Gomez Perez el año de nobenta tiene caudal y de hedad de más de quarenta años.

Anton Thomas

Anton Thomas Passo a estas yslas el año de tiene caudal. ochenta es cassado y a seruido en las ocasiones que se an ofrecido tiene caudal y sera de quarenta y quatro. años de hedad.

Alonso Garcia Bezerril Alonso Garcia Bezerril passo a estas yslas año de tiene caudal aunque poco nobenta y cinco asse ocupado en la contaduria de vuestra magestad donde al presente esta por oficial mayor della tiene algun caudal aunque poco y de hedad de treinta y cinco años.

Adrian Perez esta pobre.

Adrian Perez de Guaque passo a estas yslas por soldado con el Governador Gomez Perez y a seruido en lo que se le a mandado en esta ciudad y fuera de ella. Casose tiene treinta $\mathrm{y}$ quatro años $\mathrm{y}$ esta pobre. 
Antonio Despejo tiene caudal.
Antonio despejo cirujano passo a estas yslas el año de ochenta y quatro a hecho asistencia y exercido su oficio esta cassado $y$ tiene caudal con que passar y de hedad de quarenta años.

Antonio de olmos pobre. Antonio de olmos passo con Gomez Perez el año de nobenta en placa de sargento de una compañia de ynfanteria y a seruido de ocho años a esta parte de capitan de campañia deste pressidio con diez pesos de sueldo cada mes en esta ciudad esta cassado y es de hedad de quarenta y quatro años esta pobre.

\section{B}

El Licenciado

Blas Escoto de touar passo a estas yslas el año de tiene caudal. nobenta y tres $y$ ase ocupado en abogar y en la protetoria de los naturales destas yslas hasta que llego la rreal audiencia casose y tiene caudal es de hedad de treinta y seis años

Benito de Mendlola

Benito de Mendiola passo a estas yslas el año de tlene algun caudal. setenta y quatro a usado oflcio de procurador y a ssido protector de los naturales esta cassado tiene algun caudal sera de hedad de quarenta y cinco años.

Bernardo de castro Bernardo de Castro passo a estas yslas el año de
esta pobre.
Anda ocupado en officios a vuestra magestad en las seruir del.
de justicla.
se es de más de treinta y cinco años esta pobre.

Bartolome de Arenteria

Bartholome de rrenteria passo a estas yslas año tlene algun caudal.

de nobenta y dos esta entretenido en el officio de contador de quentas de la rreal hacienda con quinientos pesos de salario cada año tiene algun caudal es de hedad de treinta y seis años.

$\begin{array}{lcl}\text { Bernardo de Aguiar } & \text { Bernardo de Aguiar passo } & \begin{array}{l}\text { Puedese vuestra mages- } \\ \text { tad seruir dle en cosas }\end{array} \\ \text { tlene caudal. } & \text { a estas yslas el año de no- } & \begin{array}{l}\text { de justicia. } \\ \text { benta y dos asse ocupado en officios de justicia }\end{array}\end{array}$
que se le an encargado tiene caudal y sera de cinquenta y quatro años.Bernardino de Aujea Bernardino de Aujea passo a estas yslas el año de tlene caudal. : ochenta y uno y a asistido como los demas en esta ciudad es el alferez general desta ciudad tiene caudal y de hedad de treinta y cinco años.

\section{C}

Crostoual Lopez Pamo

Cristoual Lopez Pamo passo con sus padres el año esta pobre.

de ochenta casose pobremente y asi lo esta agora tiene treinta años de hedad.

Cristoual de Mercado Cristoual de iMercado passo a estas yslas el año tiene hacienda. $\quad$ de nobenta y cinco casose con la muger que fue del contador Andres Cauchela tiene veinte y seis años y hacienda con que passar en la nueva españa donde tiene sus padres. 
Cristoual de taran

Cristoual de taran soldado passo en esta plaça eata pobre año de nobenta a seruido en lo que se le a mandado fue con Don Luis Dasmariñas a canboja es casado y pobre.-

Cristoual Santos de cabra Cristoual Santos de cabra passo a estas yslas el tiene poco caudal. año de ochenta con el governador Don Gonçalo Rronquillo a seruido en las ocasiones que se an ofrecido casose $y$ tiene siete hijos y hijas tiene poco caudal. de hedad de quarenta y seis años.

$\mathrm{D}$

Capitan Don Diego de Figueroa. pobre. Anda ocupado on officlos de Justicla.

Diego de Bocanegra. pobre.

tencia de esta ciudad
Capitan Don Diego de Figueroa passo a estas yslas año de nobenta. A seruido en lo que se le a mandado tiene veinte $\mathrm{y}$ siete años esta pobre.

Diego de Bocanegra passo a estas yslas el año passado de ochenta y cinco a hecho siempre asises cassado y pobre de hedad de quarenta años.

Domingo de Artacho passo a estas yslas el año de nobenta a hecho asistencia en esta ciudad tiene tiene caudal.

algun caudai y treinta y seis años de hedad.

Dlego de Valdes. pobre. Diego de Valdes passo a estas yslas la primera vez el año de ochenta y seis y boluio el de nobenta a asistido lo que los demas tiene treinta $\mathrm{y}$ seis años de hedad a quedado pobre por perderse lo que tenia en la nao san Felipe.

Domingo de Orbea. pobre.

Domingo de Orbea passo a estas yslas año de nobenta y uno a hecho la misma asistencia. Tendra veinte y cinco años de hedad sirue la plaça de alferez de la compañia del capitan uan Juarez Gallinato.

El Alferez Esteban de Esteban Perez el viejo vino el año de sesenta y Marquina. Tiene algun
Esteban Perez pobre. gestad en las ocasiones que se an ofrecido sera de hedad de sesenta y quatro años cassado y pobre.

Esteban de Marquina passo a estas yslas año de Anda ocupado en oficios de Justicia. ochenta y dos en plaça de soldado y a seruido en esta rrepublica algunos oficios de justicia y pluma con buena aprovacion es hombre virtuoso y de sujeto para que vuestra magestad se sirua del cassado con hija del capitan Antonio de Cañedo de los primeros. Tiene treinta y quatro años de hedad tiene algun caudal.

F

Don Francisco de Castafieda esta muy pobre.

Don Francisco de Castañeda passo a estas yslas el año de nobenta y dos a

hecho asistencia en esta ciudad y agora es RegiTiene suleto para sertir a vuestra magestad en lo que se le mandare. dor della por nombramiento del governador es de edad de treinta y seis años esta muy pobre. 
Francisco Santos de Valdez Francisco Santos de Valdez vino el año de ochentiene caudal. ta es cassado tiene caudal con que passar a hecho asistencia en esta ciudad.

Capitan Francisco Navarro

tiene algun caudal. Anda ocupado en officios de justicia.

de ella ase cassado tiene algun caudal.

Francisco Franco. esta muy pobre.

El Capitan Francisco Navarro de Arrieta passo a estas yslas el año de ochenta y quatro a seruido en las Puedese vuestra magestad seruir del.

ocasiones que se an ofrecido en esta ciudad y fuera El Alferez Francisco Franco de avila passo año de nobenta a hecho asistencia en esta ciudad $y$ seruido en la del santissimo nombre de jesus la plaça de alferez de aquel pressidio y de quien vuestra magestad se puede seruir mayormente en officios de pluma de treinta años esta muy pobre.Francisco Lopez Patiño Francisco Lopez Patiño soldado. Passo a estas año esta pobre. de ochenta y quatro a seruido en lo que se le a mandado tiene quarenta $\mathrm{y}$ dos años esta pobre.

Francisco Rroman esta pobre. Francisco Rroman soldado de mas de veinte años en la tierra cassado a seruido en lo que se le a mandado en esta ciudad y fuera de ella. Tiene quarenta y dos años esta pobres.

Francisco de Valencia tiene caudal.

Francisco de Valencia es escrivano publico cassado passo a estas yslas año de ochenta y quatro a hecho asistencia en esta ciudad tiene caudal y la escrivania de que se sustenta de hedad de treinta y cinco años.

Francisco Lopez tiene alguna pasadia

Francisco Lopez soldado viejo de más de veinte $\mathrm{y}$ seis años en estas yslas a seruida en lo que se le

a mandado en algunas jornadas tiene más de sesenta años tiene alguna passadia que por estar solo se sustenta con ella y algunas ayudas de costas que se le an dado de la rreal caxa.

Gomez de molina

G

tiene caudal.

Es Regidor por nombra-

miento de Don Francisco

Tello.

Gomez de Molina Padilla

passo a estas yslas el año

Puedese vuestra magestad seruirse del.

de nobenta y cinco a hecho asistencia y agora es rregidor Por nombramiento del governador tiene caudal y de hedad de quarenta años.

Garcia de Leon pobre. Garcia de Leon passo a estas yslas el año de ochenta y quatro a seruido en algunas ocasiones esta cassado y pobre de hedad de treinta y cinco años.

Garcia de Cardenas

Garcia de Cardenas passo a estas yslas el año de tiene caudal.

nobenta tiene caudal con que passar y de hedad

de más de quarenta años.

Garcia de Ballesteros

Garcia de Ballesteros passo con sus padres a esmuy pobre.

tas yslas año de ochenta $y$ dos a seruido en lo que se le a mandado tiene treinta años de hedad. Esta muy pobre. 
$\mathbf{H}$

Hernando de los Rrios Hernando de los Rrios coronel passo a estas partiene algun caudal. tés el año de ochenta y Puedese vuestra magesocho a hecho asistencia en esta ciudad y seruido tad seruir del. en ella en lo que se le a mandado $y$ en algunos officios de justicia con buena aprovación fue por capitan de ynfanteria con Don Luis Perez Dasmariñas a la jornada de canboja es hombre virtuosso y de talento para qualquiera cossa que vuestra magestad le mande tiene hedad de quarenta años y algun caudal.

Hernan Sanchez

tiene algun caudal.
Hernan Sanchez a ssido capitan de galera passo a estas yslas el año de ochenta y quatro $\mathrm{y}$ a ser-

Hernan Sanchez pobre.

Hernan Sanchez cassado passo año de nobenta y uno a hecho asistencia en esta ciudad tiene más de quarenta años esta pobre.

Hernando de castro

Hernando de Castro passo año de ochenta y dos pobre. con sus padres y hermanos a hecho asistencia tiene veinte $y$ cinco años esta pobre.

Hernando Rramirez Botica- Hernando Rramirez Boticario passo a estas yslas rio tiene caudal. el año de nobenta y uno esta entretenido en su Botica tiene caudal con que passar de hedad de treinta y cinco años.

\section{$\mathbf{J}$}

Capitan encomendole Don Francisco Tello en una encomienda de Juan Xuarez Gallinato sargento mayor deste campo passo a estas yslas con el dicho oficio y con el goquinientos tributos vaco por vernador Don Gomez $\mathrm{Pe}$ muerte del Capitan Osorio. rez Dasmariñas año de no-

Puedese vuestra magestad seruir del en cossas de momento de justicia $y$ de guerra.

benta y a seruido a vuestra magestad en las ocasiones y jornadas de mas ynportancia que en su tiempo se an ofrecido exerciendo los dichos oficios con su paga. Es cassado puedese vuestra magestad seruir del en qualquier cosa de momento y de justicia y de guerra esta pobre.

Capitan Juan de villegas. El Capitan Juan de Villegas vino el año de noCasado.

Encomendole Don Francisco Tello en 600 yndios en benta con compañia de soldados y a seruido muy bien Puedese vuestra mages-

Cagayan. esta pobre sera de hedad de quarenta años.-

Juan sardo tiene caudal Es Regidor por Don Francisco Tello.

Juan sardo Regidor desta ciudad passo a estas yslas año de ochenta y dos a seruido de oficial mayor de la contaduria y contador de la rreal ha-

cienda tiene quarenta años y caudal con que passar esta cassado.

EI Alferez

Anda ocupado por Maestre de una nao de la carrera de nueva españa.
Juan Ruiz de Ycoaga passo a estas yslas año de ochenta y ocho a seruido en lo que en su tiempo se a ofrecido tendra trein-
Puredese vuestra magestad ocuparie en su seruircio. 
ta $y$ seis años esta pobre. Puede vuestra magestad ccuparle en su seruicio.

E capitan no esta mico. Julian de cuenca passo a estas yslas año de tiene quarenta y seis años no esta rrico.

Juan de Mujlca

Juan de mujica passo a estas yslas año de noben-

tlene algun caudal. benta a hecho asistencia en esta ciudad y seruido en lo que se le a mandado tíene algun caudal. de hedad de treinta y quatro años puede vuestra magestad ocuparle en su seruicio en especial en materia de pluma.

EI alferez

tiene caudal.
Juan Tello de Aguirre passo a estas yslas el año de nobenta a hecho asistencia y seruido en lo que se le a mandado casose $y$ tiene caudal y es de hedad de treinta y siete años.

Jeronimo de Herrera. esta pobre.
Jeronimo de Herrera passo a estas yslas año de nobenta $y$ dos a hecho

Puede vuestra magestad

asistencia y seruido en lo que se le a mandado serulrse del.

señeladamente en la rreal contaduria en cosas de ynportancia tiene sujeto para que vuestra magestad se sirua del en este ministerio por que se a criado en el es de hedad de treinta años y esta pobre.

Alferez Juan Gallardo El alferez Juan Gallardo vino a estas yslas año de pobre. ochenta y tres a hecho asistencia y seruido en lo que se le a mandado y esta ocupado en el oficio de teniente de alcaide de un fuerte desta ciudad sera de hedad de quarenta años y esta pobre y cassado.

Juan Grauiel de godoy Juan Grauiel de Godoy passo a estas yslas año de pobre. nobenta y cinco siruio el oficio de solicitador del rreal fisco por nombramiento de la audiencia rreal es de hedad de veinte y seis años y pobre.

wusepe Jimenez tiene algun caudal.
El alferez Jusepe Jimenez passo por soldado el año de ochenta y quatro a seruido en to que se le a mandado y se a ofrecido en su tiempo es de hedad de treinta y cinco años. Tiene algun caudal puede vuestra magestad seruirse del.

\section{L}

Don Lorenco de Figueroa algun caudal. Esta ocupado en el offlclo de factor de la rreal hacienda.
Don Lorenço de Figueroa passo a estas yslas año de nobenta $y$ tres a hecho asistencia $y$ seruido el officio Puede vuestra magestad seruirse del.

de factor de la rreal hacienda $y$ otros de ynportancia, que se le an encargado tiene más de quarenta cinco años y algun caudal puede vuestra magestad seruirse del en lo que fuere seruido de ocuparle. 
El alferez esta pobre. Don Luis de Ballesteros passo a estas yslas año de nobenta y uno y a ser-

euido en el campo desta ciudad de alferez y en las puede vuestra magestad ocasiones que fuera de ella se an ofrecido tiene seruirse del. treinta y cinco años y esta pobre puede vuestra magestad ocuparle en su seruicio.

Luis de Balmazeda

tiene caudal.
Luis de Balmazeda passo a estas yslas el año de nobenta a hecho asistencia y seruido en lo que se le a mandado tiene caudal con que passar y de hedad de treinta y cinco años y de quien vuestra magestad puede seruirse.

$\mathbf{M}$

El Capitan pobre.
Esta ocupado en la alcal-
dia del parian por
Don Francisco Tello.

Don Mathias de Landecho passo a estas yslas la primera vez a mas tiempo Puede vuestra magestad de veinte años despues Bol- seruirse del.

uio de la nueva España el de nobenta y cinco a hecho asistencia y primero avia seruido en algunas jornadas es cassado y esta pobre por averse perdido en la nao san Felipe donde yua por cavo a la nueva españa tiene sujeto para seruirse vuestra magestad del.-

Melchor de Baeza Melchor de Baeza passo a estas partes el año de tiene caudal. setenta y ocho asse ocupado en oficio de procuraEsta proveldo en este oflclo dor y servido en lo que se le a mandado haciendo por nombramiento de $\quad \ldots$ asistencia en esta ciudad agora sirue el oficio de Don Francisco Tello. protector de los sangleyes con seiscientos pesos de salario tiene mas de quarenta y seis años y algun caudal con que passar.Melchor de Figueroa. pobre.

Anda ocupado en oflcios de Justicla.

Don Melchor de Figueroa passo el año de ochenta a hecho asistencia en estas yslas y ocupadose en oficios de justicia esta pobre.

\section{N}

Nicolas de Salzedo Nicolas de Salzedo passo a estas yslas el año de pobre. ochenta y quatro a hecho asistencia en esta ciudad y ocupadose en la guarda de los almazenes rreales que a tenido a su cargo por orden de los oficiales de la rreal hacienda y agora queda entretenido en esta ocupacion tendra quarenta años y esta cassado e pobre.

\section{$\mathbf{P}$}

Pedro de Vargas hurtado Pedro de Vargas Hurtado passo a estas yslas año pobre. $\quad$ de ochenta y quatro a ser- Puedese vuestra magesuido en lo que se le a mandado en esta ciudad y tad seruir del. fuera de ella en Zibu la plaça de Castellano del fuerte de alli esta muy pobre tiene mas de quarenta años de hedad.-

Pedro Godinez xara Pedro Godinez Xara passo el año de nobenta a tiene caudal. hecho asistencia en esta ciudad tiene caudal con que passar y mas de quarenta años de hedad. 
Pedro Patifio. pobre.

Pedro Patiño passo a estas yslas año de cchenta y quatro sirue el oficio de portero de la "rreal" audiencia esta cassado y con hijos y pobre tiene hedad de mas de cincuenta años.

Pedro Perez de segura. Pedro Perez de Segura passo a estas yslas año de pobre. ochenta y quatro a seruido en algunas jornadas es cassado y pobre tiene hedad de quarenta años.

Pedro del puerto. pobre. Pedro del Puerto passo a estas yslas año de ta y quatro años a hecho asistencia en esta ciudad como los demas.-

R

Roque Espino de Roque Espino de Cacerez de hedad de veinte y Cacerez ocho años passo a estas ys

las por poblador con su casa y ffamilia a tiempo de más de tres años a estado ocupado en materia de papeles de que es muy avil es sujeto para que su magestad le ocupe en este ministerio y de justicia y hacienda queda siruiendo la escrivania de registros destas yslas por nombramiento del

Puedese vuestra magestad seruil del. Particularmente es este officio que se propone por aver a quien mejor se le pueda confirmar. governador a que acude bien.

Otros pobres ay distraidos de que no se haze aqul caudal pero con todo esto hazen aqui Rostro y podria vuestra magestad ser seruido mandar se les ayude con algo que si en alguna parte de las yndias a lugar el dispensar que los governadores acudan al rremedio destos tales es en esta governación.

Don Francisco Tello

(Firmado) 